University of Nebraska - Lincoln

DigitalCommons@University of Nebraska - Lincoln

1980

State of Stress in the Conterminous United States

Mary Lou Zoback

U.S. Geological Survey, marylouz@stanford.edu

Mark D. Zoback

U.S. Geological Survey, zoback@stanford.edu

Follow this and additional works at: https://digitalcommons.unl.edu/usgsstaffpub

Part of the Earth Sciences Commons

Zoback, Mary Lou and Zoback, Mark D., "State of Stress in the Conterminous United States" (1980). USGS Staff -- Published Research. 453.

https://digitalcommons.unl.edu/usgsstaffpub/453

This Article is brought to you for free and open access by the US Geological Survey at DigitalCommons@University of Nebraska - Lincoln. It has been accepted for inclusion in USGS Staff -- Published Research by an authorized administrator of DigitalCommons@University of Nebraska - Lincoln. 


\title{
State of Stress in the Conterminous United States
}

\author{
MARY LOU ZOBACK AND MARK ZOBACK
}

\author{
U.S. Geological Survey, Reston, Virginia 22092
}

\begin{abstract}
Inferring principal stress directions from geologic data, focal mechanisms, and in situ stress measurements, we have prepared a map of principal horizontal stress orientations for the conterminous United States. Stress provinces with linear dimensions which range between 100 and $2000 \mathrm{~km}$ were defined on the basis of the directions and relative magnitude of principal stresses. Within a given province, stress orientations appear quite uniform (usually within the estimated range of accuracy of the different methods used to determine stress). Available data on the transition in stress direction between the different stress provinces indicate that these transitions can be abrupt, occurring over $<75 \mathrm{~km}$ in places. In the western United States, a region of active tectonism characterized by high levels of seismicity and generally high heat flow, the stress pattern is complex, but numerous stress provinces can be well delineated. Despite relative tectonic quiescence in the eastern and central United States, a major variation in principal stress orientation is apparent between the Atlantic Coast and midcontinent areas. Most of the eastern United States is marked by predominantly compressional tectonism (combined thrust and strike slip faulting), whereas much of the region west of the southern Great Plains is characterized by predominantly extensional tectonism (combined normal and strike slip faulting). Deformation along the San Andreas fault and in parts of the Sierra Nevada is nearly pure strike slip. Exceptions to this general pattern include areas of compressional tectonics in the western United States (the Pacific Northwest, the Colorado Plateau interior, and the Big Bend segment of the San Andreas fault) and the normal growth faulting along the Gulf Coastal Plain. Sources of stress are constrained not only by the orientation and relative magnitude of the stresses within a given province but also by the manner of transition of the stress field from one province to another. Much of the modern pattern of stress in the western United States can be attributed to present transform motion and residual thermal and dynamic effects of Tertiary subduction along the western edge of the North American plate. Abrupt stress transitions around actively extending regions in the western United States probably reflect shallow sources of stress and anomalously thin lithosphere. Large areas characterized by a uniform stress field in the central and eastern United States suggest broad scale plate tectonic forces. In the midcontinent region, both ridge push and asthenospheric viscous drag resistance to lithospheric motion can explain the NE-SW compression in the cold, thick lithosphere of the craton, although drag-induced stress directions (resistance to absolute plate motion) correlate better with the data than do the ridge push directions. Asthenospheric counterflow models do not apply in this region, as predicted stress orientations are about $90^{\circ} \mathrm{off}$. A region of compression oriented approximately perpendicular to the continental margin and Appalachian fold belt is defined by the stress data along the Atlantic Coast. This NW-SE compression is in direct contrast with previous models predicting extension perpendicular to passive continental margins due to lateral density contrasts at the continental-oceanic crust interface. Ridge push forces, while capable of producing a component of compression across the coastal area, do not explain the observed orientation of the stress. Two speculative mechanisms are suggested to explain the observed orientations: (1) rotation of stress (or strain) due to anisotropic Appalachian basement structure and (2) flexural effects associated with erosion and isostatic rebound of the Appalachians.
\end{abstract}

\section{INTRODUCTION}

Detailed knowledge of the pattern of intraplate stress provides important constraints on models of global tectonic processes and the mechanism of plate motions. On a finer scale, both the pattern of stress and variations in the pattern must be known to understand intraplate volcanism and tectonism properly. In addition, in regions of relative tectonic quiescence, knowledge of the in situ stress field is required for delineation of potential seismic hazards associated with preexisting zones of weakness in the crust.

This study represents an attempt to map the modern stress field (primarily Quaternary in the western United States and Tertiary and younger in the East) in the conterminous United States. Principal stress orientations have been determined from geologic observations, earthquake focal mechanisms, and in situ stress measurements. An attempt has also been made to categorize broad regions not only by the orientations of the principal stresses but also by their relative magnitudes, as inferred from currently active tectonism.

This paper is not subject to U.S. copyright. Published in 1980 by the American Geophysical Union.

Paper number 80B 1093 .
Data are presented in terms of the orientation and relative magnitude of maximum and minimum horizontal stresses and a vertical stress. We have assumed that one principal stress is vertical, and the horizontal components of the in situ stress field represent principal stresses. Evidence supporting this assumption includes observations of the nearly vertical attitude of dikes exposed over significant depth intervals at a given locality [R. B. Johnson, 1961] as well as the absence of exposed dikes that appear not to have been emplaced vertically (D. Pollard, oral communication, 1980). In addition, measurements of the complete stress tensor in deep mines [McGarr and Gay, 1978] and the near-horizontal orientations of the great majority of stress axes inferred from earthquake focal mechanisms also indicate that regionally the principal stresses are horizontal and vertical.

The major contribution of the present study is the inclusion of new geologic data on the orientation of the stress field, largely in the western United States. In addition, we have attempted to go back to the original references and check the reliability of previously compiled data, particularly for focal mechanisms. We have excluded poorly constrained points and have relied, whenever possible, on averages of a number of so- 
lutions in a given locality. The quality criteria used are detailed below.

\section{Principal Stress Orientation Indicators}

Some discussion is warranted of the different techniques used for determining principal stress orientations, especially the major assumptions associated with each technique as well as the inherent difficulties and uncertainties. Incorporation of the geologic stress indicators is our main contribution to previous compilations of stress data.

\section{Geologic Data}

Geologic information on principal stress orientations can be divided into two main categories: observations of fault slip and the alinements of young ( $<5$ m.y. B.P., predominantly Quaternary) volcanic feeders. For the western United States, many of these data came from $M$. L. Zoback [1979], Thompson and Zoback [1979] and M. L. Zoback and M. D. Zoback [1980]. In the east, geologic data on young faulting compiled by Prowell [1980] was especially useful.

Detailed information on fault slip can be used to determine the net horizontal component of motion on oblique slip normal and thrust faults. Measurements of fault slip direction yield the net direction of horizontal shortening in the case of oblique slip thrust faults, and the net horizontal extension direction on oblique slip normal faults. The occurrence of oblique slip suggests slip on favorably oriented preexisting planes of weakness (i.e., faults). We assume here that the actual horizontal slip direction reflects the regional stress field. Available strain data for the western United States indicate that the regional stress and strain axes, in general, do coincide [e.g., Prescott et al., 1979], and in detail, in situ stress and regional strain measurements at the Nevada Test Site yield consistent principal axes [S. W. Smith and R Kind, 1972; Haimson et al., 1974]. Thus in a normal faulting regime, such as in the Basin and Range and the Gulf Coast provinces, the horizontal component of slip (or opening) is inferred to be regionally in the direction of the least principal stress. Similarly, in a thrust faulting regime the net horizontal slip should be in the direction of the greatest principal stress.

The actual direction of slip on a preexisting fault plane $o c-$ curs in the direction of maximum resolved shear stress on that plane when the ratio of shear to normal stress exceeds the frictional strength. To predict accurately the direction of slip on a fault with a given orientation, both the orientation of the regional principal stresses and their relative magnitudes must be known [e.g., Wallace, 1951]. Thus it is impossible to infer uniquely principal stress orientations from observations of slip on a single fault. However, if slip observations are made for a family of faults influenced by a single regional stress field, then these observations can be inverted to determine the orientation of the principal stresses [e.g., Angelier, 1979; Carey, 1979]. Unfortunately, such detailed studies have not been done in the United States. The fault slip data included here constrain only the approximate principal stress orientations.

Two methods of determining fault slip geologically are from measurements of (1) historic offsets and (2) grooves and slickensides on exposed fault scarps. Of these two methods, data from the first are often the most difficult to obtain and the least reliable. Surface scarps of earthquakes are rarely a single trace but rather a zone of breaks, so a complete picture of slip requires knowledge of the total dip slip and strike slip components of motion for all breaks. However, if a major break can be identified, the maximum vertical and strike slip offsets (along the same segment of the break) can be used to determine the net horizontal components of slip.

Large-scale grooves and parallel slickensides on an exposed fault surface indicate the relative direction of motion of two crustal blocks. Unfortunately, well-preserved fault scarps in competent rocks are rarely exposed. In the Basin and Range province, a region of abundant Quaternary faulting, most young scarps occur in alluvium, basinward of the main ranges. However, surface exposures of fault scarps are known and are sometimes exposed several kilometers (occasionally tens of kilometers) along strike. Measurement of grooves and slickensides at a number of sites along a fault provides a mean horizontal direction of slip for a major crustal block. Consistency of the horizontal component of slip despite changes in strike of as much as $90^{\circ}$ [M. L. Zoback, 1978; Pavlis and Smith, 1980] indicates that these grooves and slickensides accurately record the major block motion. One source of error in this kind of study is the possibility of a local downdip component of motion of gravitationally unstable blocks that slide down into the valley. This source of error could result in measured slip directions that are spuriously rotated toward the valley.

Some of the geologic slip data reported here were derived from detailed studies involving a number of localities on a given fault surface, whereas other data represent only a single measurement (see Table 1 for details). The standard deviation of the mean horizontal component of slip in the detailed studies is $\pm 10^{\circ}-15^{\circ}$, which is probably a reasonable estimate of the accuracy of all the fault slip data despite the fact that individual measurements generally have a precision of $\pm 2^{\circ}$.

An additional method of determining fault slip utilizes recent observations of core holes offset by motion on preexisting fault surfaces. These core hole offsets are considered to be reliable stress indicators when (1) fault motion occurs years after excavation, and (2) the sense of motion is not caused by the creation of a stress-free surface and thus is gravitationally controlled (see the work of Schäfer [1979] in the Appalachian Fold Belt).

Where detailed information on the direction of slip is unavailable, an approximate method for determining stress orientation relies on the trend of young faults and the sense of only the predominant type of offset (generally vertical, either normal or reverse). This method has been used for the Atlantic Coastal Plain and Gulf Coast areas. The assumption of purely dip slip faulting for active Gulf Coast normal faults is probably valid. For the Atlantic Coastal Plain this method was used because it provided the only available data; however, the possible errors are recognized as potentially being quite large (perhaps as large as $20^{\circ}-30^{\circ}$; see Wallace [1951] and Raleigh et al. [1972]).

The second type of geologic indicator of principal stress orientation is linear volcanic feeders, such as dikes and cinder cone alinements, where the cinder cone alinement presumably reflects the geometry of an underlying fissure or dike. $E$. $M$. Anderson [1951] and Odé [1956] have concluded on theoretical grounds that dike intrusion should follow planes perpendicular to the axis of least principal stress within a rock mass, resulting in magma-fracing [Yoder, 1976] analogous to hydraulic fracturing. Clearly, there can be no static shear stress across a magma-filled crack, and numerous examples exist of dike swarms that crosscut earlier structures and maintain a constant trend in rocks containing abundant preexisting 
fractures and faults [e.g., Christiansen and McKee, 1978, p. 294]. Koons [1945], in a careful study of late Quaternary basalt fields north of the Grand Canyon, saw through the possible confusion of parallel cinder cone alignments and nearby faults:

Detailed examination of exposed bedrock near these aligned groups shows that, though the lines of cones parallel fault trends the cones do not lie on observed fault lines ... cones tend to occur in distinct lines, parallel to, but not associated with, observed surface fractures. This parallelism may have resulted from stresses in existence at the time of deformation.

In addition, Nakamura [1977] and Nakamura et al. [1978] convincingly demonstrated the correspondence between linear volcanic feeders and regional stress as determined from studies of active faults, earthquake focal mechanisms, and the direction of convergence along major plate boundaries. Thus in regions of active volcanism, linear volcanic feeders can be used to determine principal stress orientations. Lachenbruch and Sass [1978] also have suggested that the axis of maximum elongation of calderas should correspond to the regional least principal stress direction. In the present study, however, we have used only dike trends and cinder cone alinements which can be determined with greater precision.

Stress directions inferred from cinder cone alinements are generally based on linear alinements of four or more vents. Some of these linear zones are quite impressive, extend for nearly $20 \mathrm{~km}$, and contain as many as 16 individual eruptive centers (e.g., the Don Carlos Hills in northeastern New Mexico, site NM-22, Table 1). Dike trends are based on a visual regional average in which the longest and most continuous dikes generally are given the greatest weight. Again, as in the case of the fault slip data, individual measurements may be made with an accuracy of $\pm 1^{\circ}-2^{\circ}$. However, variations in any given area suggest that a more reasonable assessment of the reliability of the stress orientation determination is $\pm 5^{\circ}-10^{\circ}$.

Measured ellipticity of wells resulting from caving of walls (breakouts) has also been proposed as a principal stress indicator. Cox [1970] and Babcock [1978] have reported consistent orientations of elongations within individual wells and between wells distributed over an area of more than $3 \times 10^{5}$ $\mathrm{km}^{2}$ on the high plains of Alberta, Canada. In one $200 \times 250$ $\mathrm{km}$ region, nine wells showed only a $20^{\circ}$ variation in mean predominant elongation orientations (azimuths: $130^{\circ}, 135^{\circ}$, $140^{\circ}, 142^{\circ}, 142^{\circ}, 143^{\circ}, 146^{\circ}, 146^{\circ}, 150^{\circ}$ ). These consistent orientations are independent of lithologic and age boundaries as well as dip of the strata. Bell and Gough [1979] have suggested that the breakouts responsible for these elongations are caused by concentration of stresses at the walls of wells with the direction of elongation coinciding with the least horizontal principal stress orientation. Utilizing experimentally derived stress magnitudes required to produce spalling, they suggest that at least one of the horizontal stresses must exceed the lithostat indicating a compressional (strike slip or thrust faulting) stress regime.

Finally, some discussion is warranted regarding the age of the geologic stress field indicators utilized in our study. In the western United States, only features younger than $5 \mathrm{~m}$.y. and generally younger than $3 \mathrm{~m}$.y. were included. (The ages of specific sites are listed under 'comments' on Table 1.) Considerable stress field uniformity is found over this time period in several areas. In the eastern United States, two groups of data were used: the data in New England represent postglacial and Holocene faulting; the tectonism in the Atlantic Coastal Plain, however, can only be shown to be of Tertiary or Quaternary age.

\section{Focal Mechanisms}

Pressure $P$ and tension $T$ axes derived from earthquake focal mechanisms are one of the most commonly used indicators of tectonic stress. However, principal stress orientations obtained from fault plane solutions are inherently the least reliable indicators of stress orientation because the $\boldsymbol{P}$ and $T$ axes cannot be equated with certainty to the greatest and least principal stress directions. McKenzie [1969] demonstrated that for the general case of triaxial stress the only restriction on the greatest principal stress imposed by the fault plane solution is that this stress direction must lie in the same quadrant as the $\boldsymbol{P}$ axis but could, in fact, be nearly normal to the $\boldsymbol{P}$ direction. McKenzie's objections were based largely on the fact that most shallow crustal earthquakes occur on preexisting faults rather than by the fracturing of intact homogeneous material and that shear stresses at shallow depths are much too small to cause failure. Raleigh et al. [1972], however, pointed out that the strength of intact homogeneous rock is such that new faults will be generated where faults exist at unfavorable orientations. Experimentally derived faulting relations reported by Raleigh et al. suggest that only preexisting planes lying at $\sim 10^{\circ}-50^{\circ}$ to $S_{1}$, the greatest principal stress direction, would slip (i.e., when $S_{1}$ is between $40^{\circ}-80^{\circ}$ to the normal to the fault plane). Therefore they concluded that the $P$ axis (taken as lying at $45^{\circ}$ to the fault plane) could be in error by no more than $35^{\circ}-40^{\circ}$ when sliding on a preexisting fault produces the earthquake. Furthermore, they suggested that if the nodal plane corresponding to the fault is known, the $\boldsymbol{P}$ axis (corresponding to the greatest principal stress) should be plotted at $60^{\circ}$ of the normal of the fault plane and at $30^{\circ}$ to the slip direction. In this case the orientation of the greatest principal stress would be in error by no more than $20^{\circ}$.

However, selection of the actual fault plane is frequently difficult and the $P$ and $T$ axes standardly reported are at $45^{\circ}$ to the nodal planes. Thus it appears that the best method of analyzing focal mechanism data is to consider a number of earthquakes occurring on different faults in a particular area and then to rely on average $P$ and $T$ directions. In this way the errors due to slip on preexisting planes of various trends should hopefully tend to cancel, and the correct average $P$ and $T$ directions will be obtained. $M$. L. Zoback and $M$. D. Zoback [1980] compared extension directions on major faults in the northern Basin and Range, determined using fault slip data, with the $T$ axes of focal mechanisms. Despite large scatter in the focal mechanism data (standard deviation, $\pm 25^{\circ}$ ), the mean directions and the geologically determined extension directions fall within $3^{\circ}$ of one another; this result suggests that the $T$ axes are fairly reliable indicators of principal stress/strain directions. Both $R$. B. Smith [1977] and Eaton [1979] have also noted that regionally good correlation between earthquake $P$ and $T$ axes and nearby in situ stress data throughout the United States. However, as outlined in the previous paragraph, stress directions derived from individual focal mechanisms could be in error as much as $35^{\circ}-40^{\circ}$. We have attempted to rely, whenever possible, on average $P$ and $T$ directions from a number of solutions in any given area.

The best seismic coverage is in California, where detailed studies have been made of focal mechanisms along segments of the San Andreas fault. From these studies the mean $\boldsymbol{P}$ and 


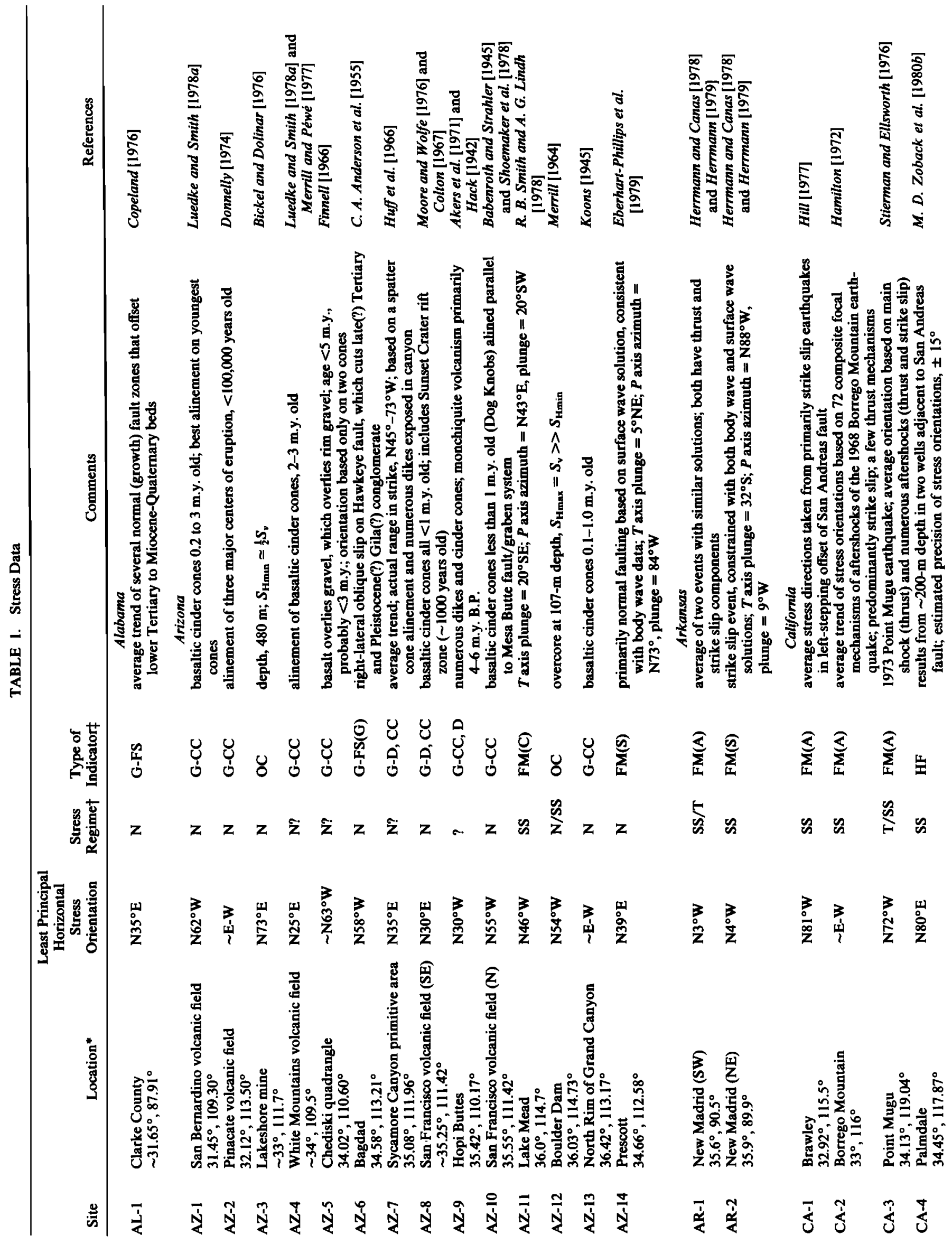




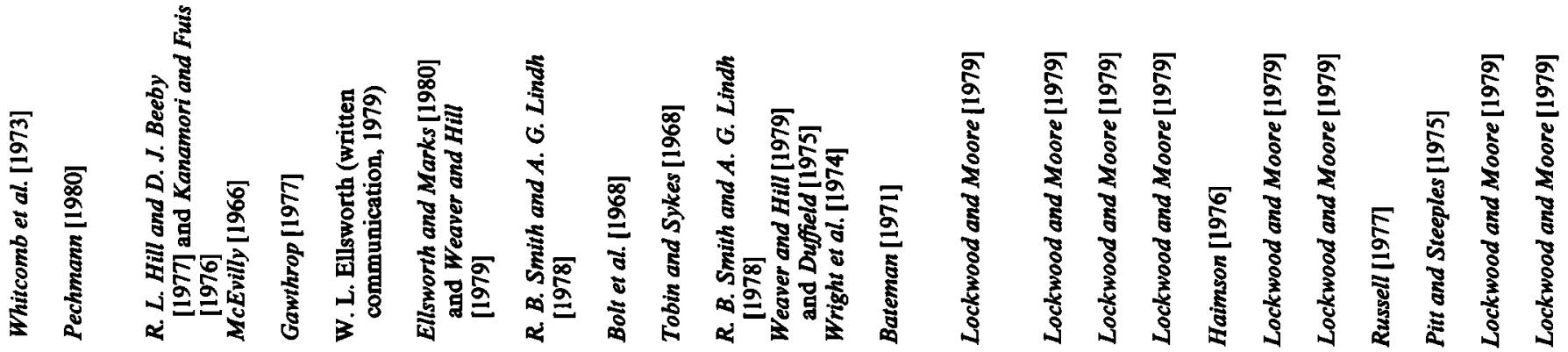
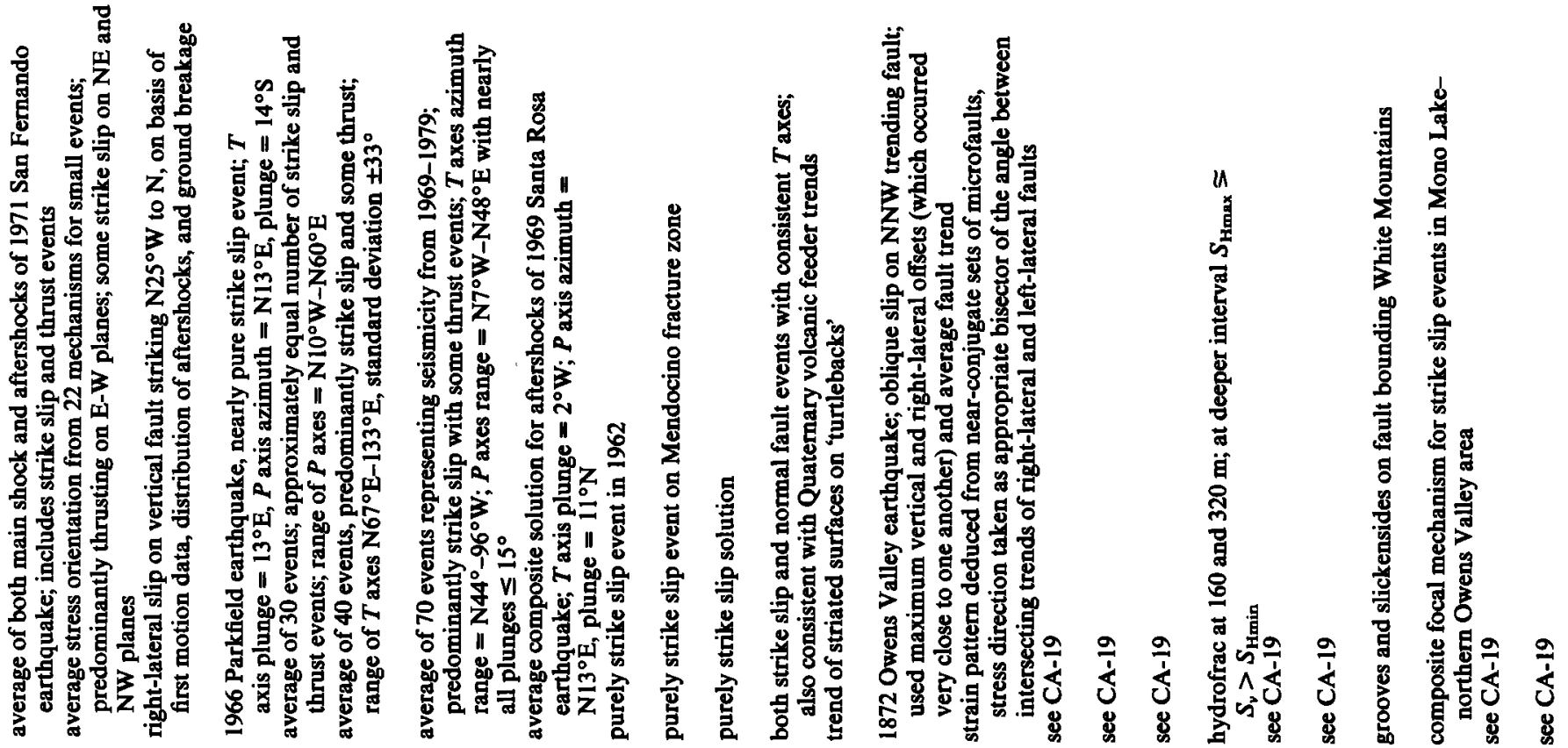

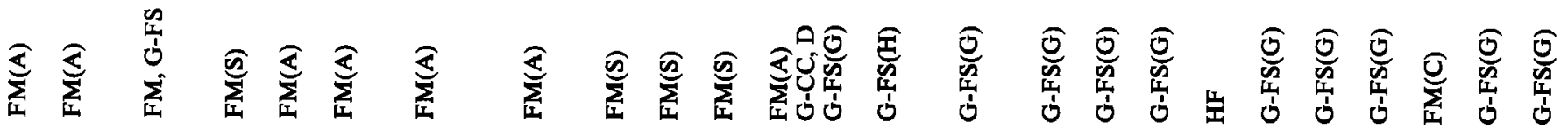

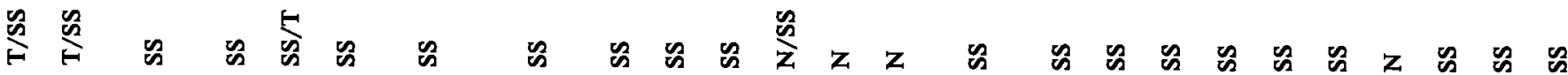

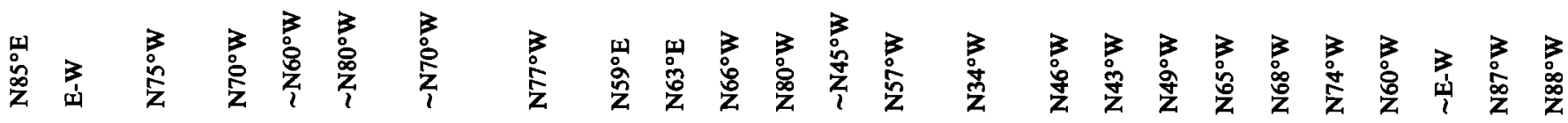

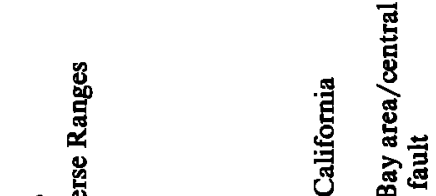

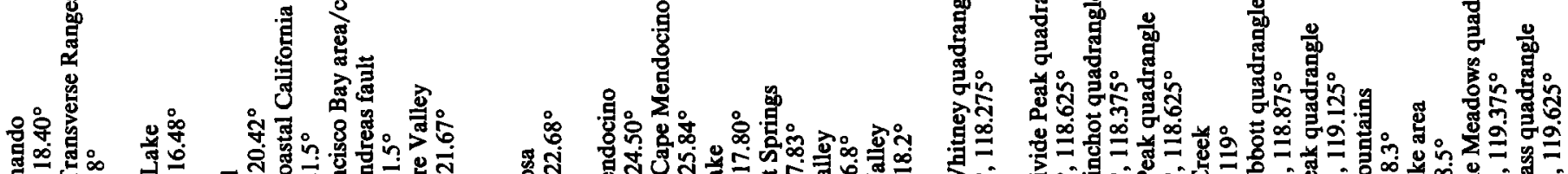

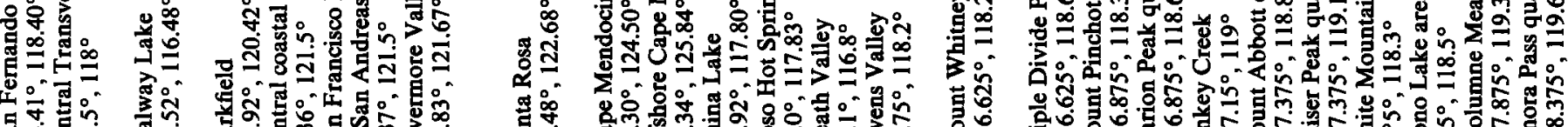

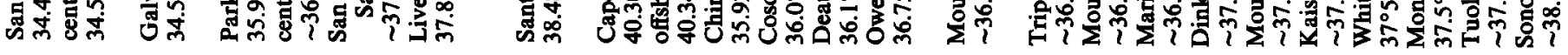

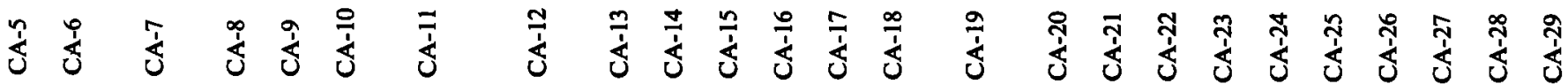




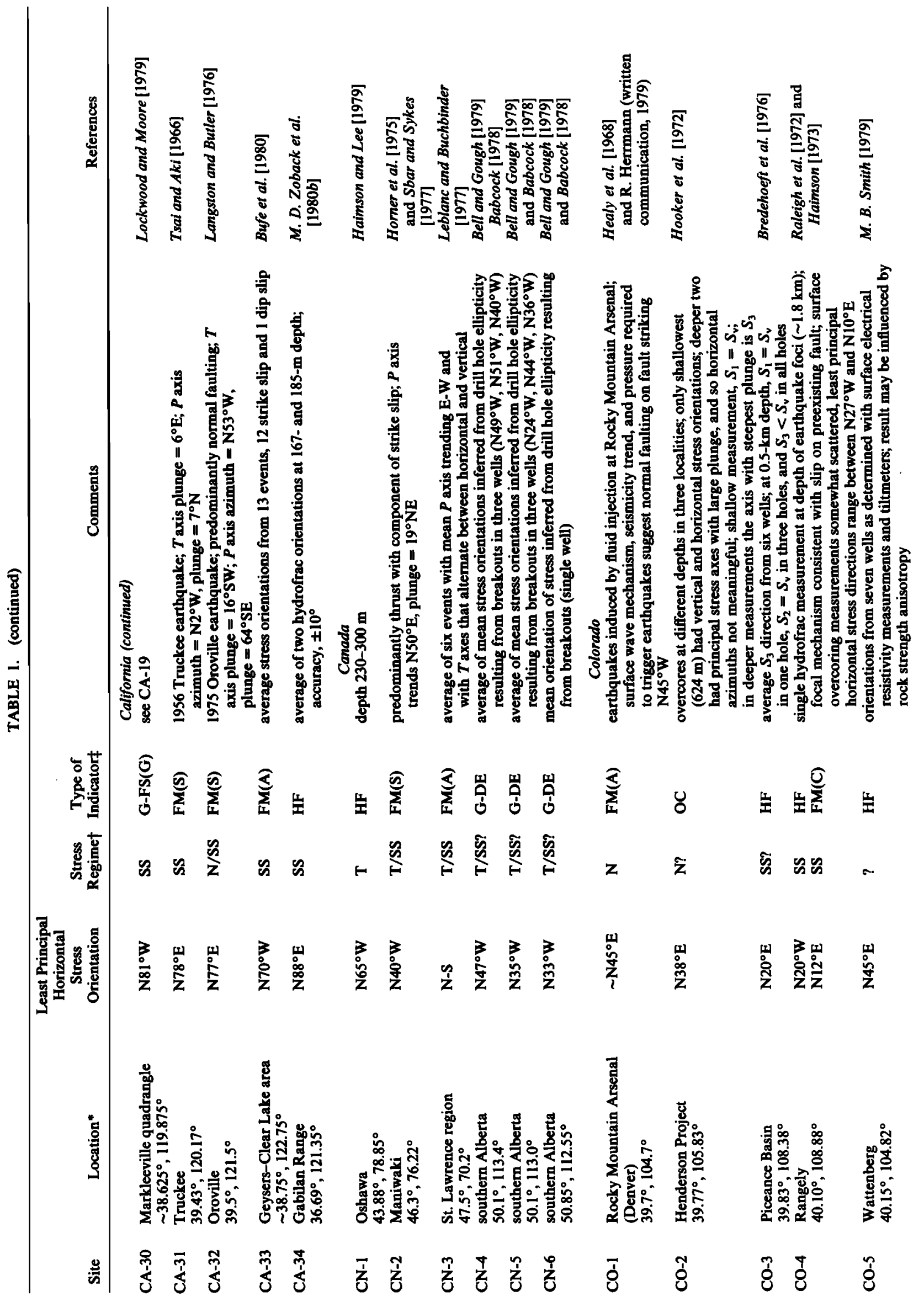



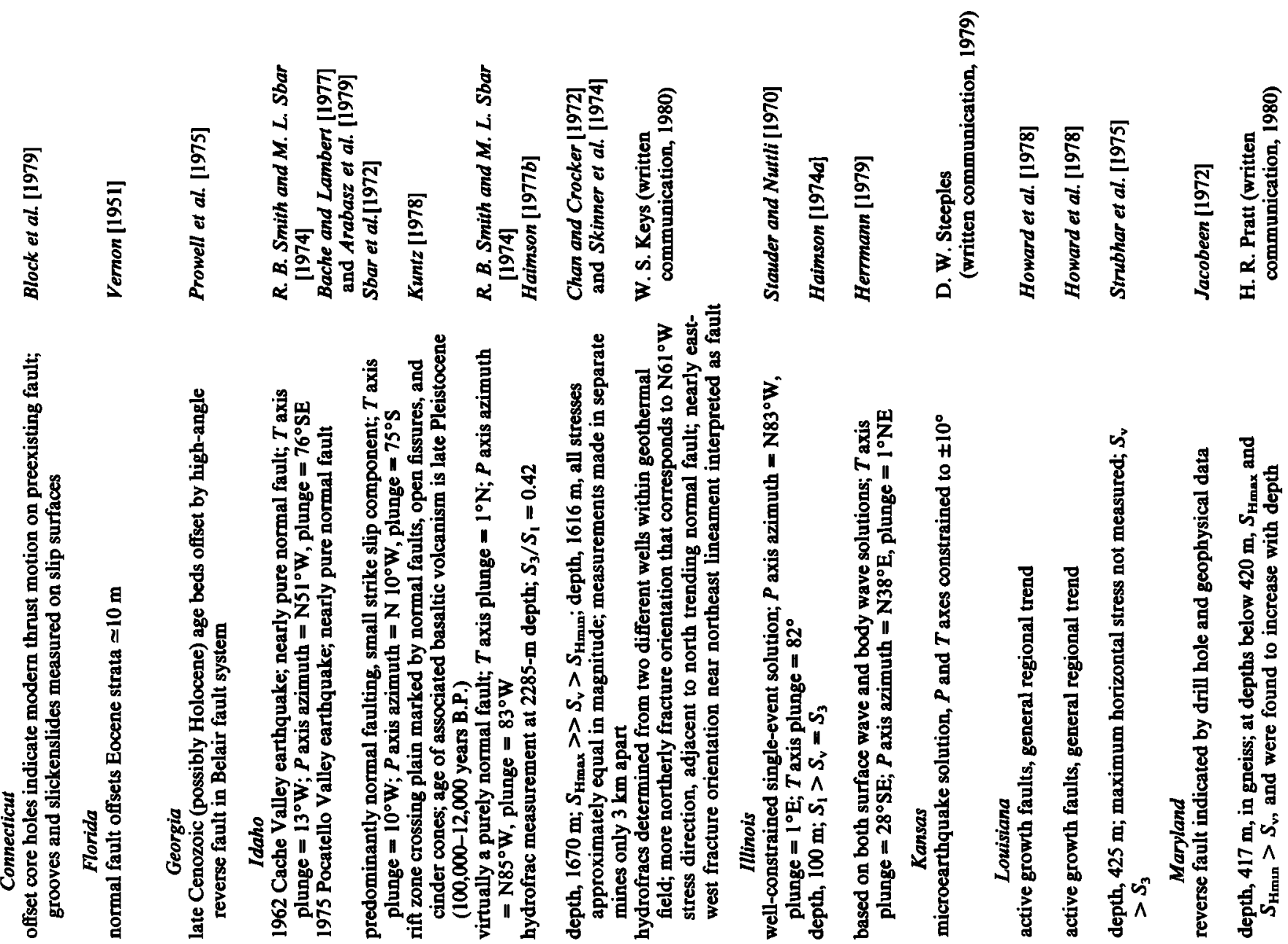

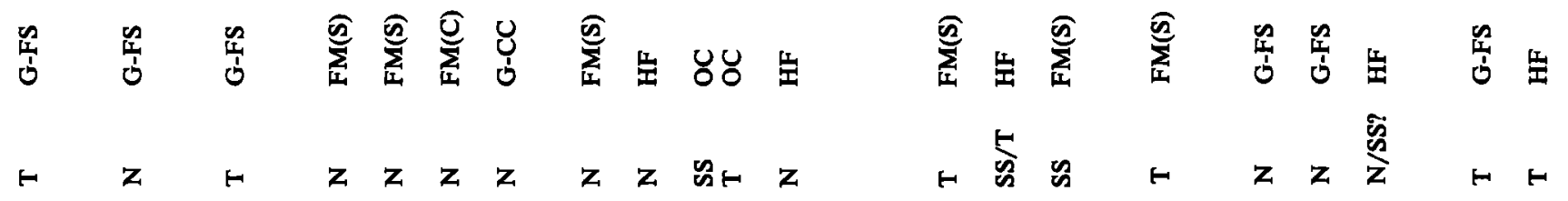

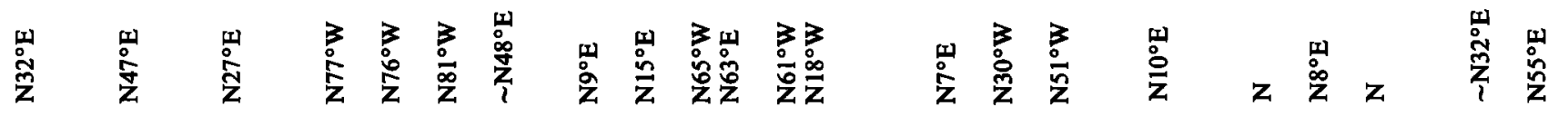

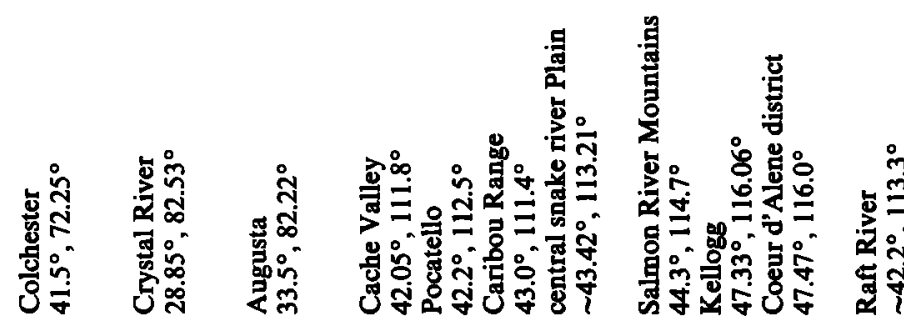

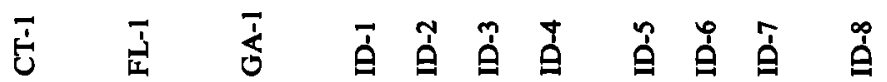




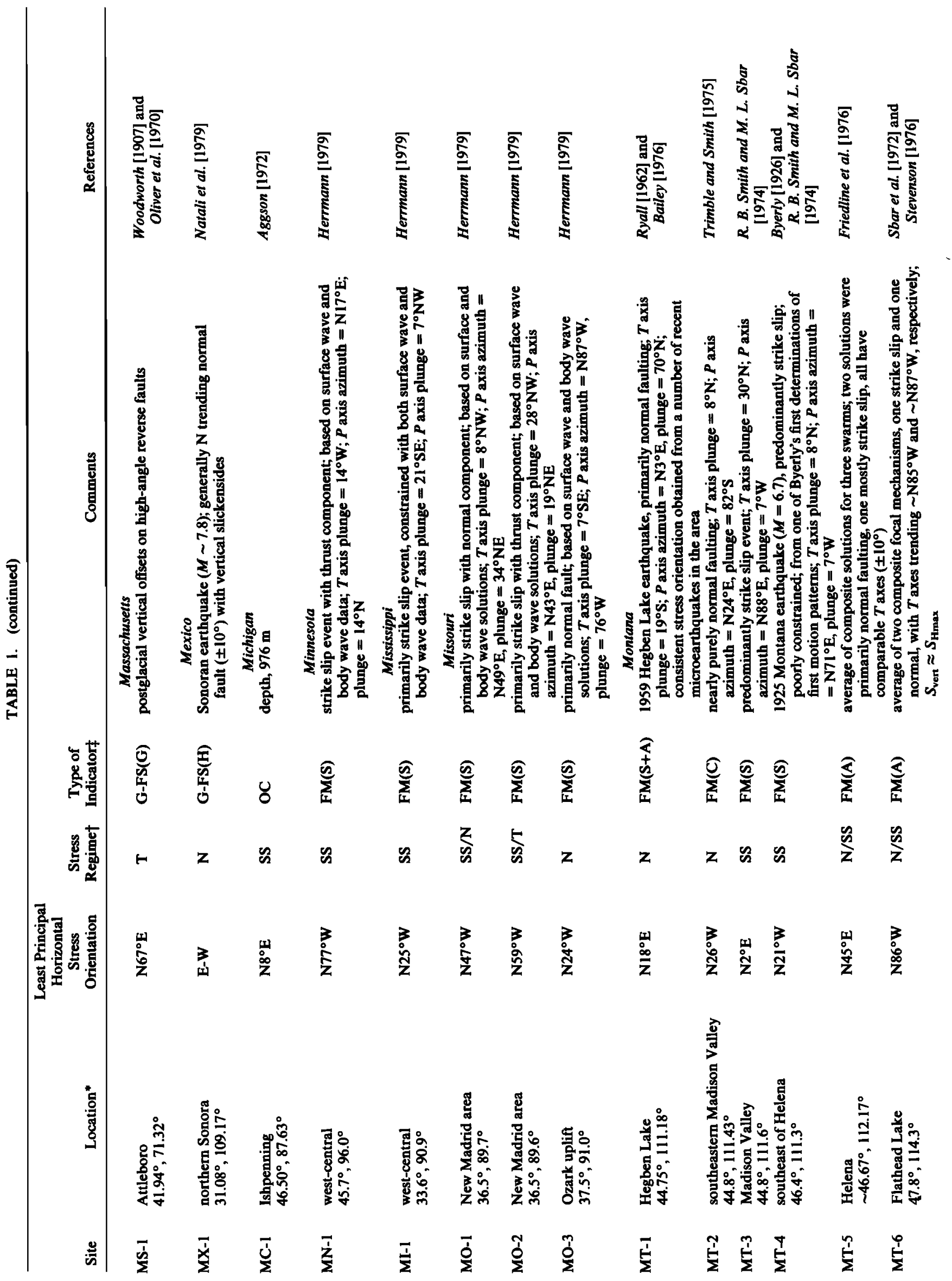



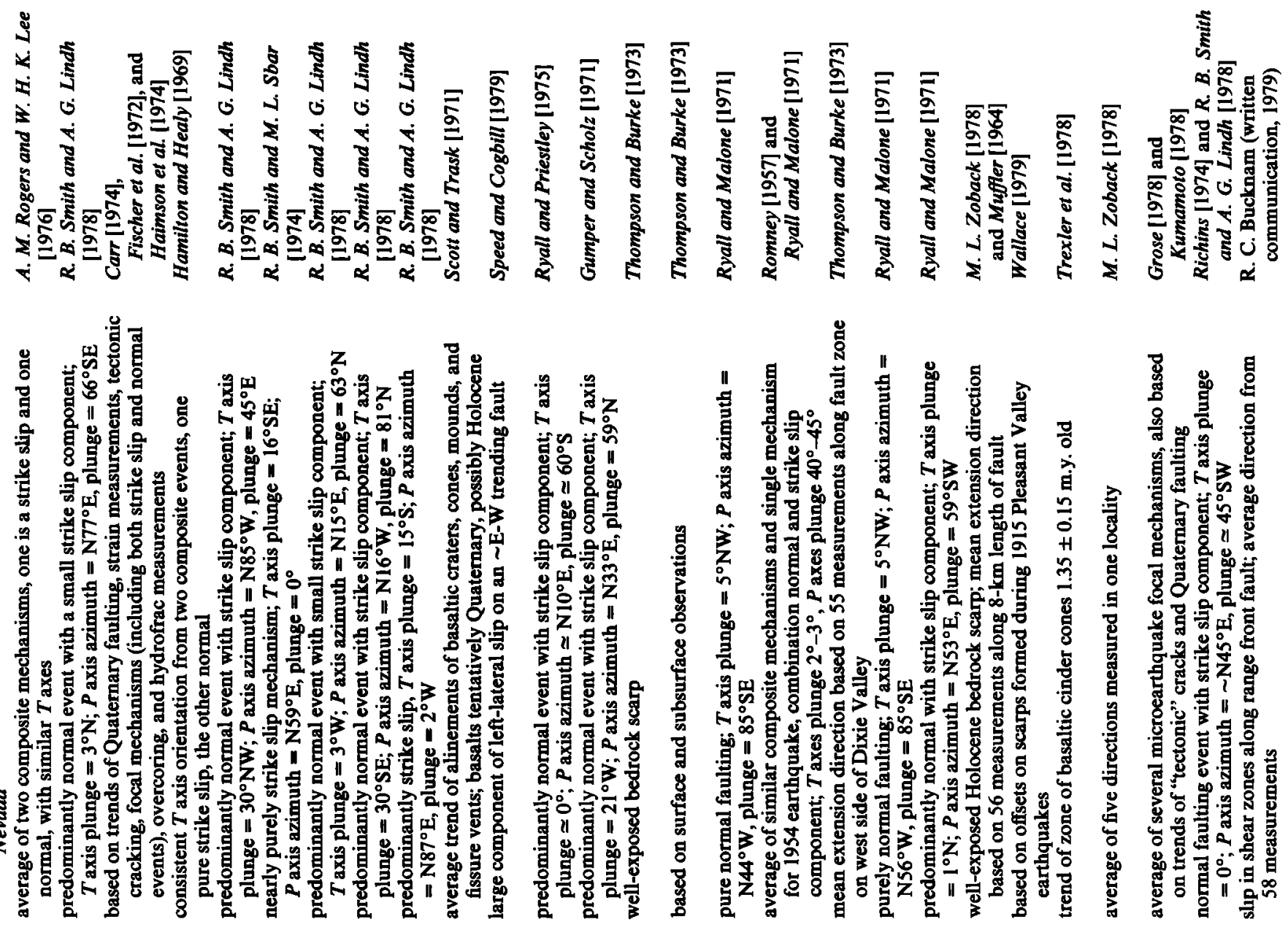

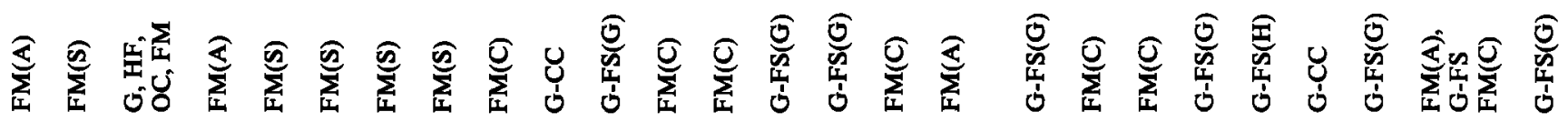

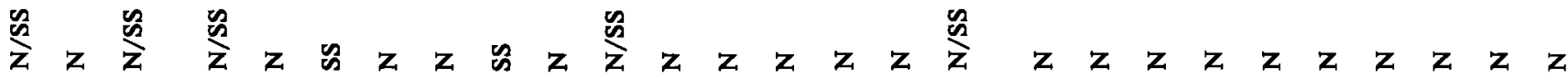

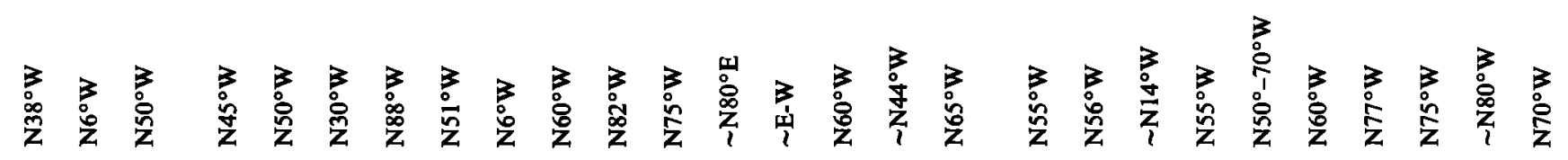

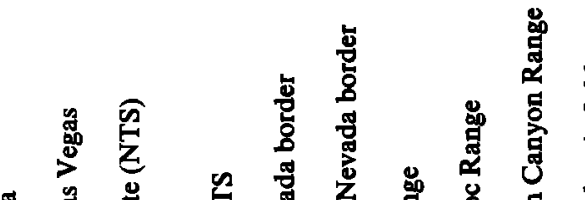

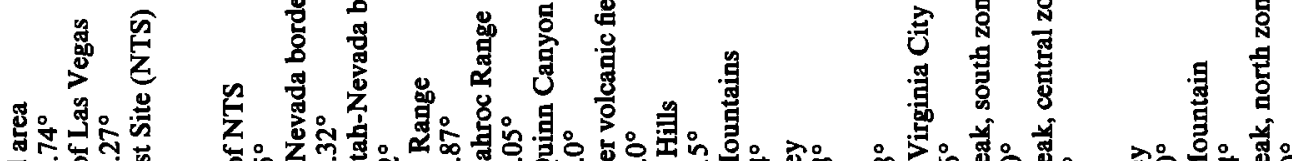

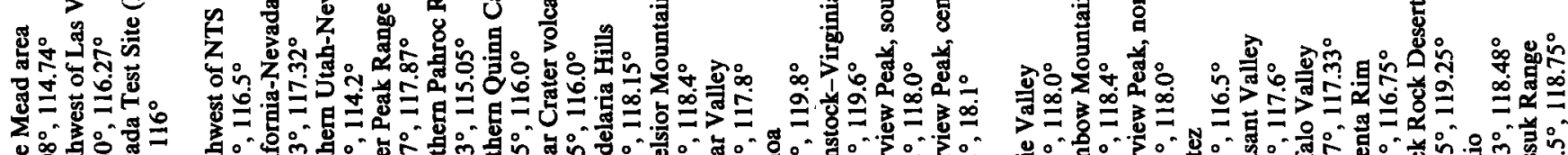

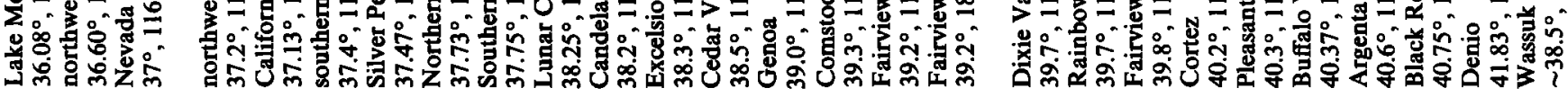

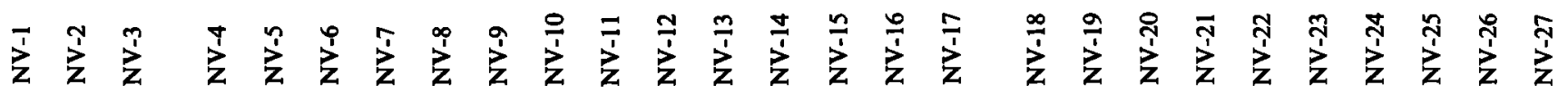




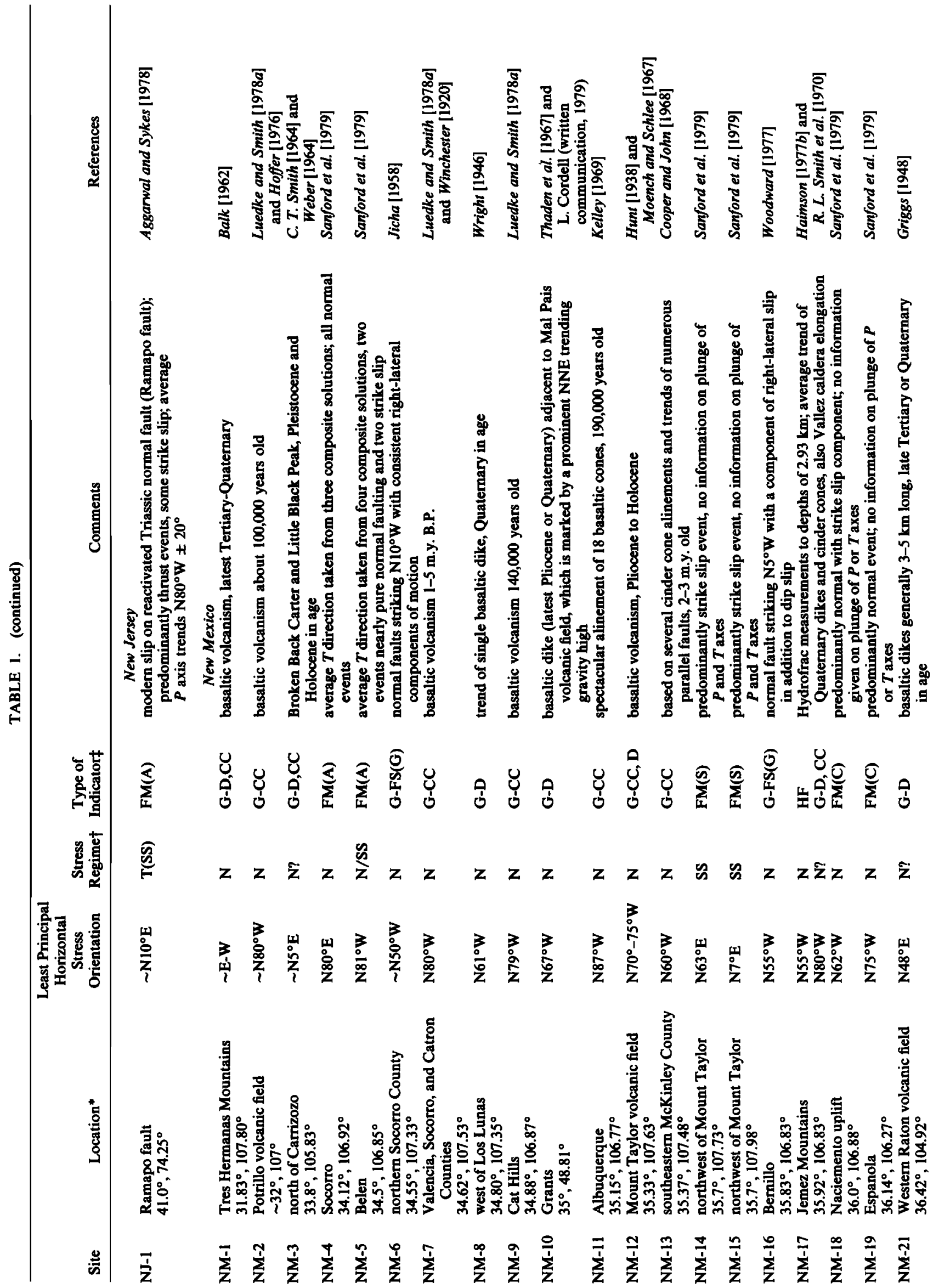




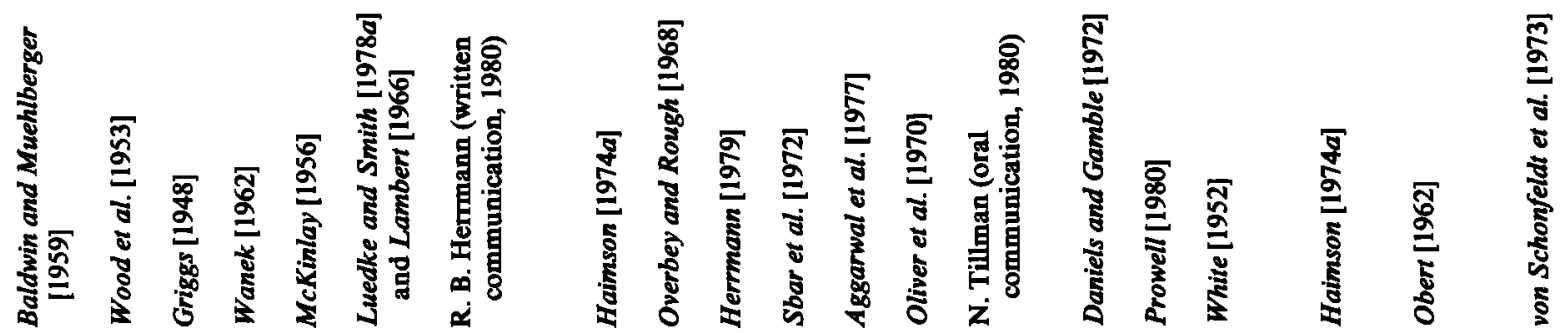
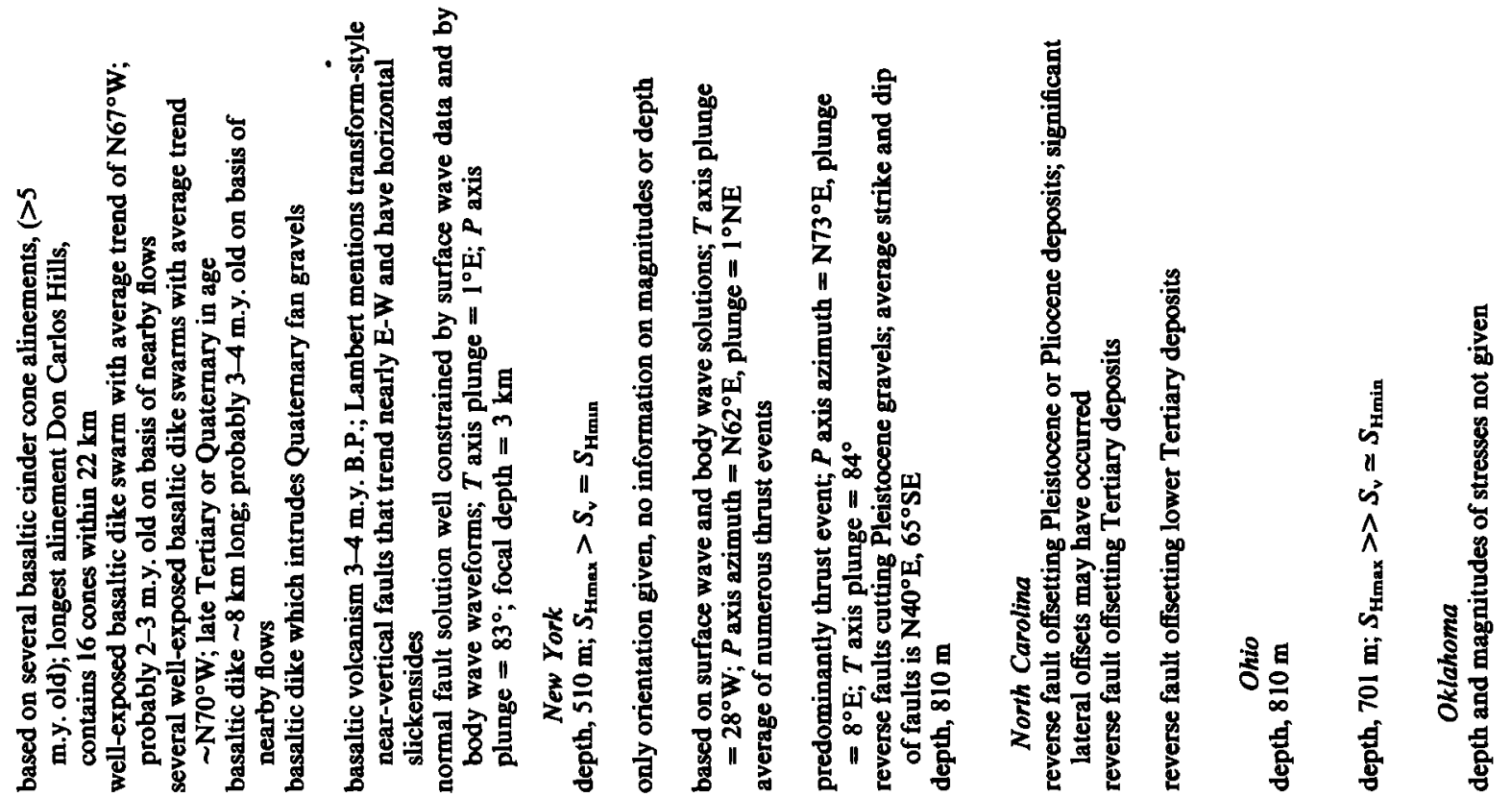

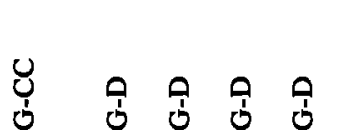

足

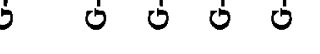

文云云云zz

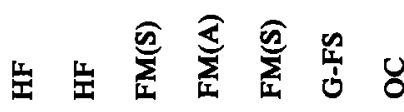

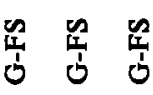

是 8 宝

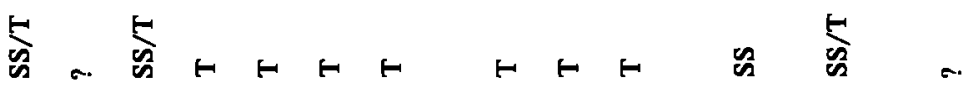

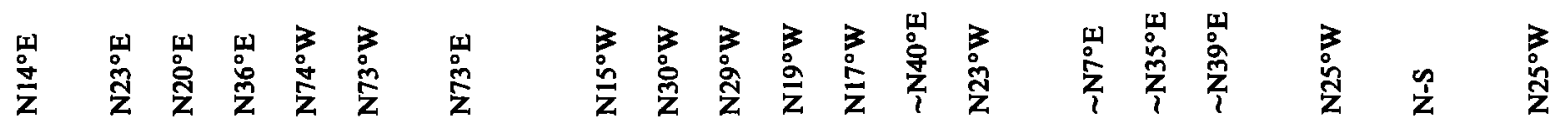

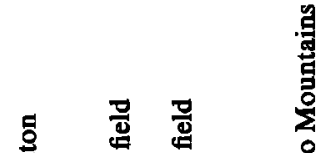

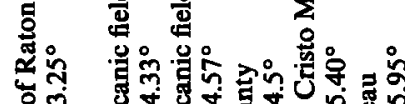

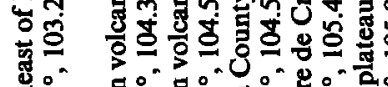

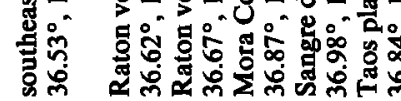

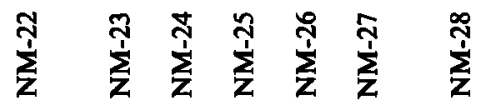

\section{产}

育害

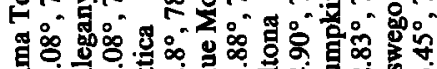

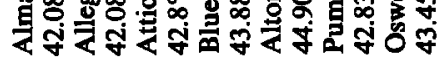

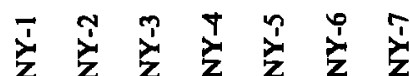

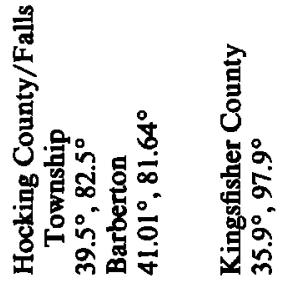

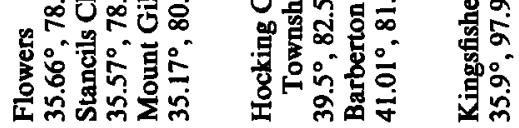




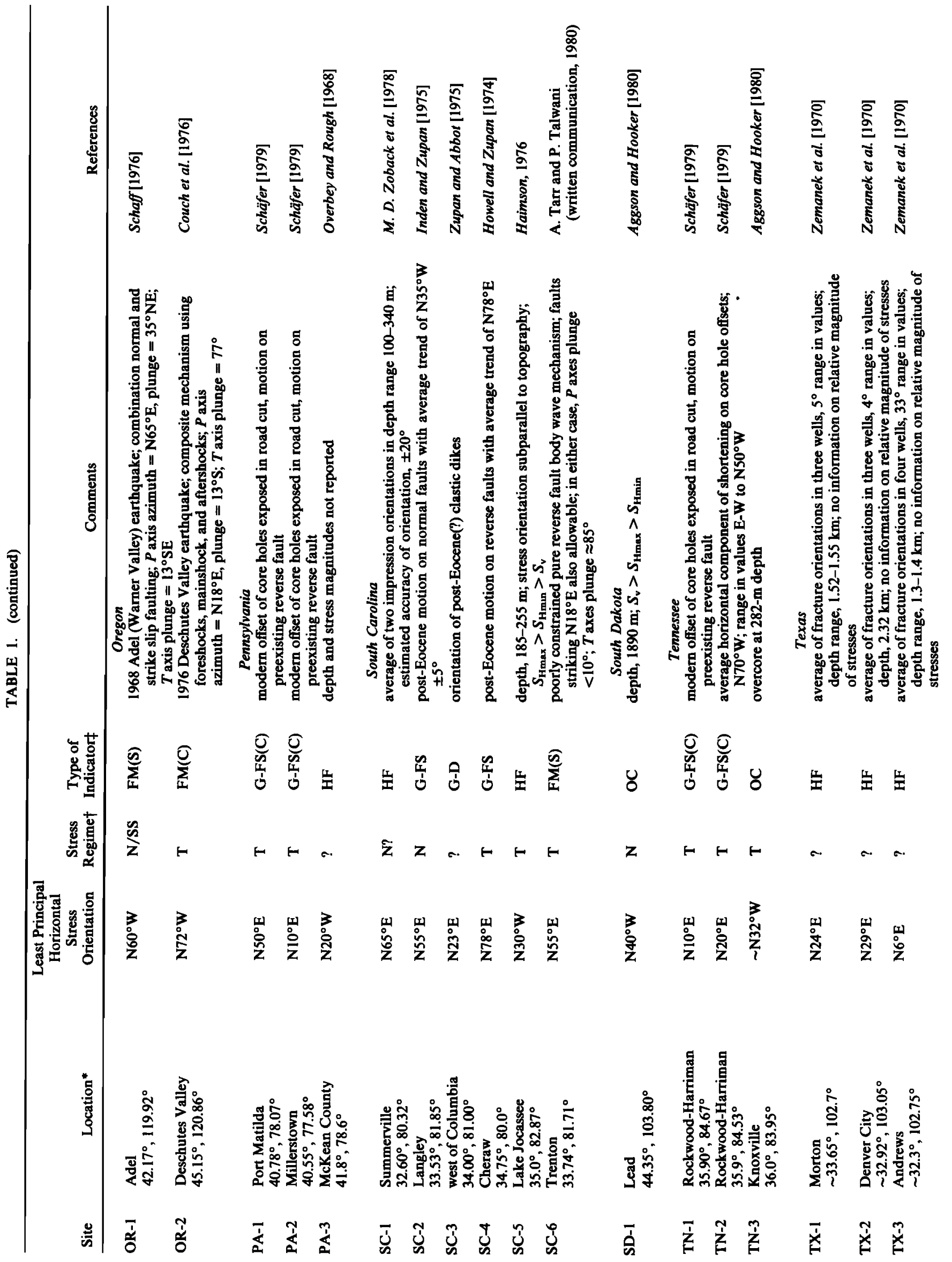



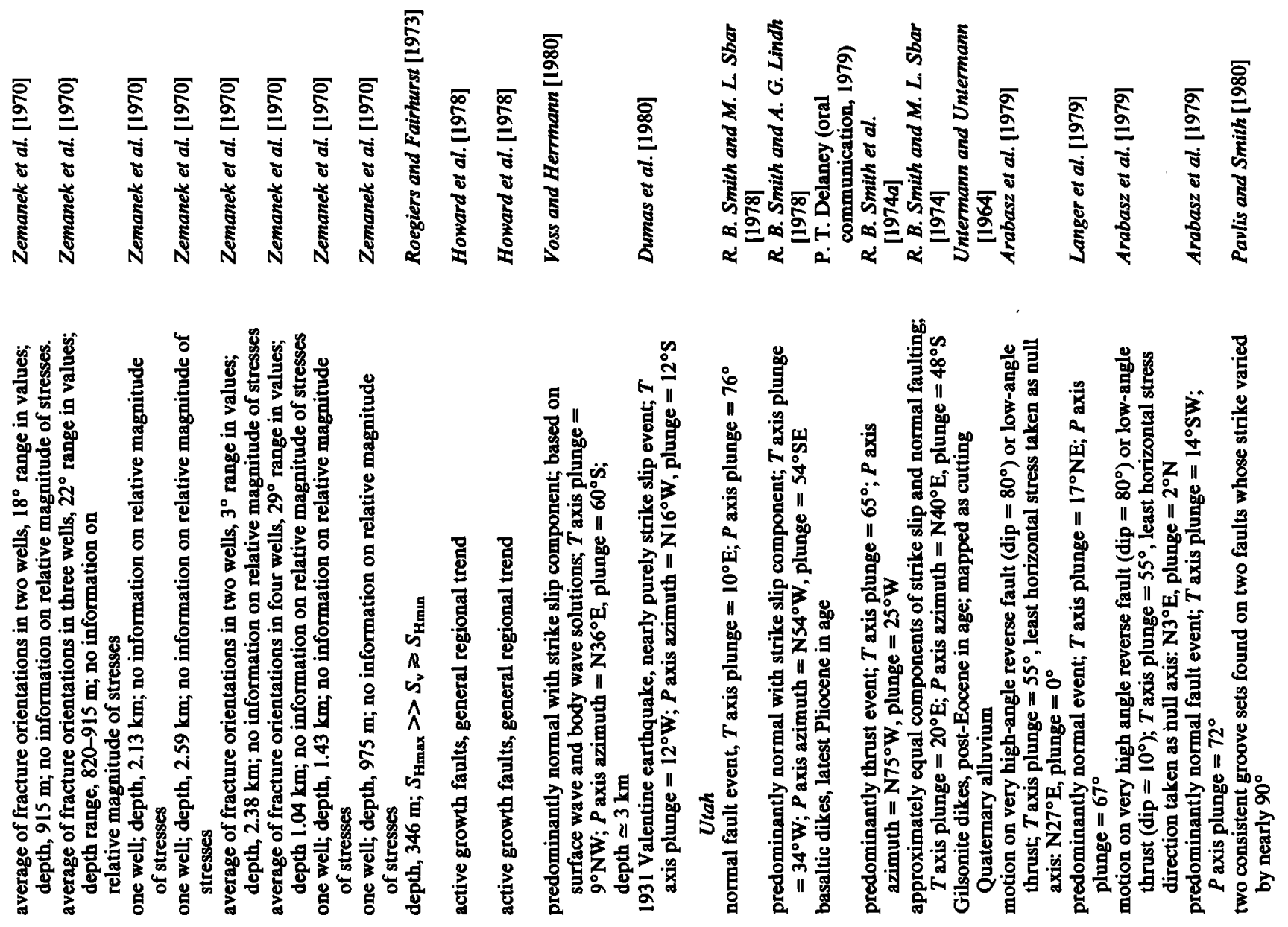

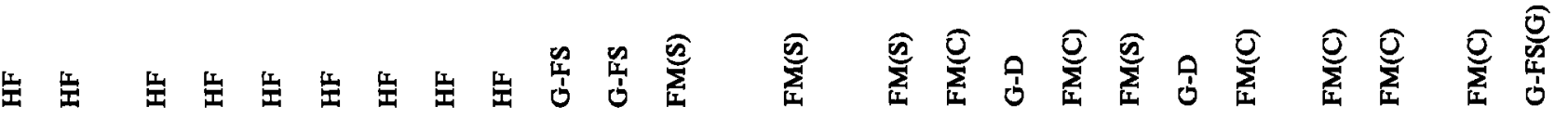

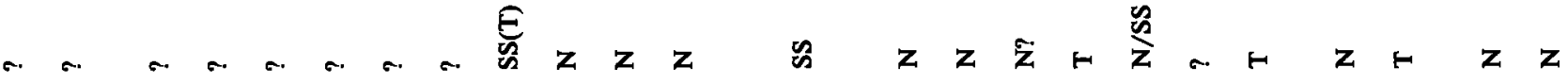

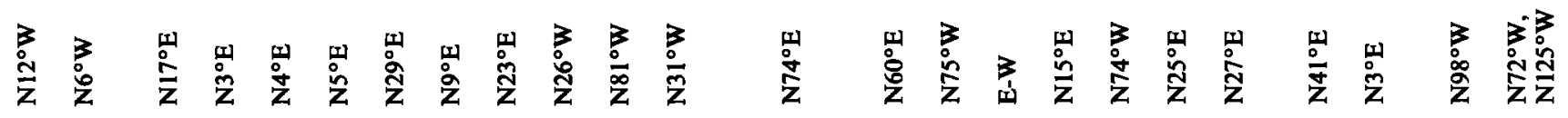

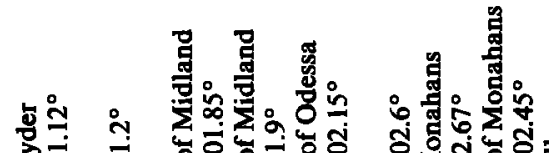

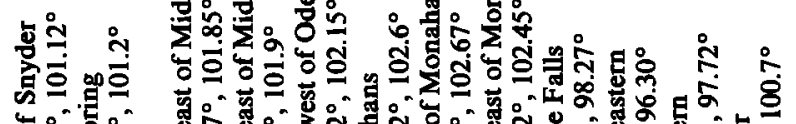

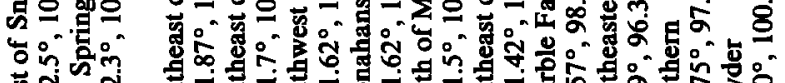

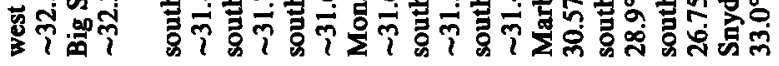

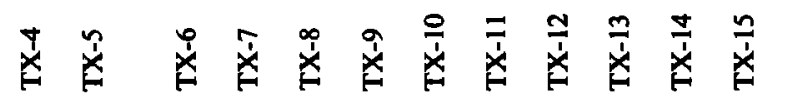

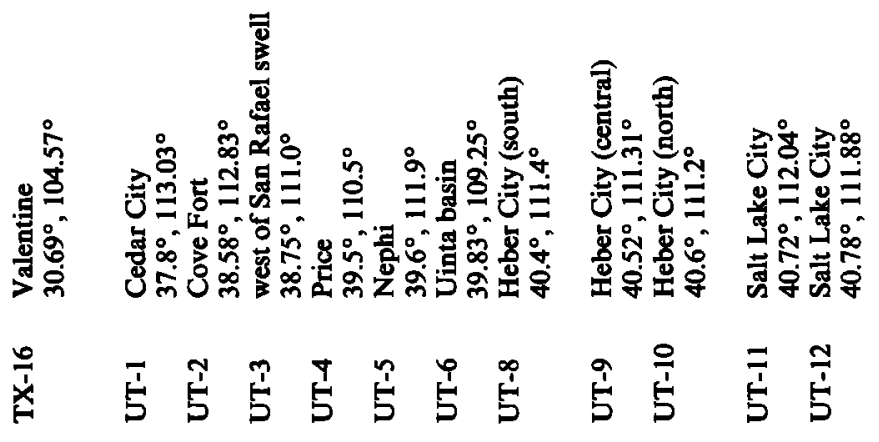




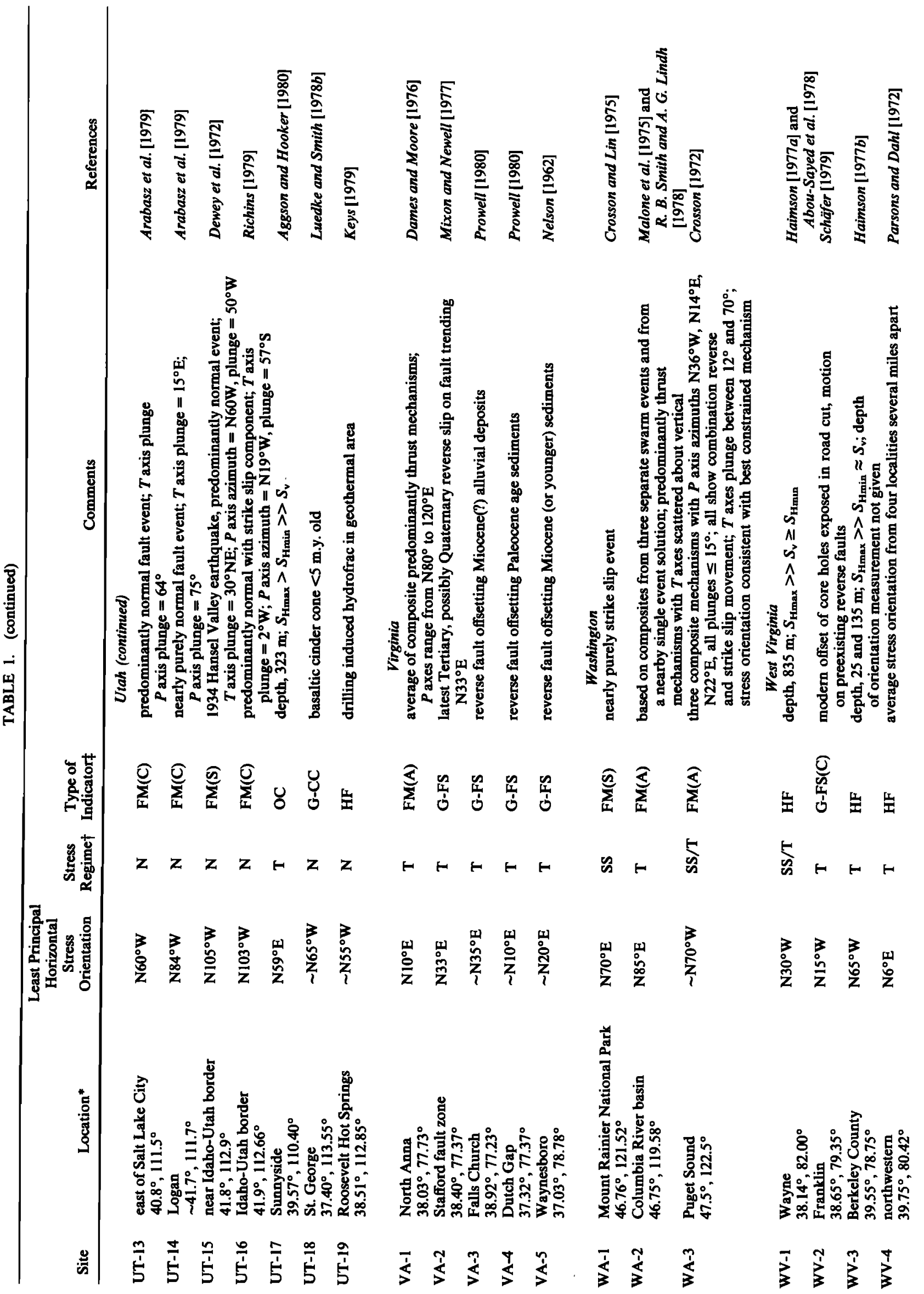



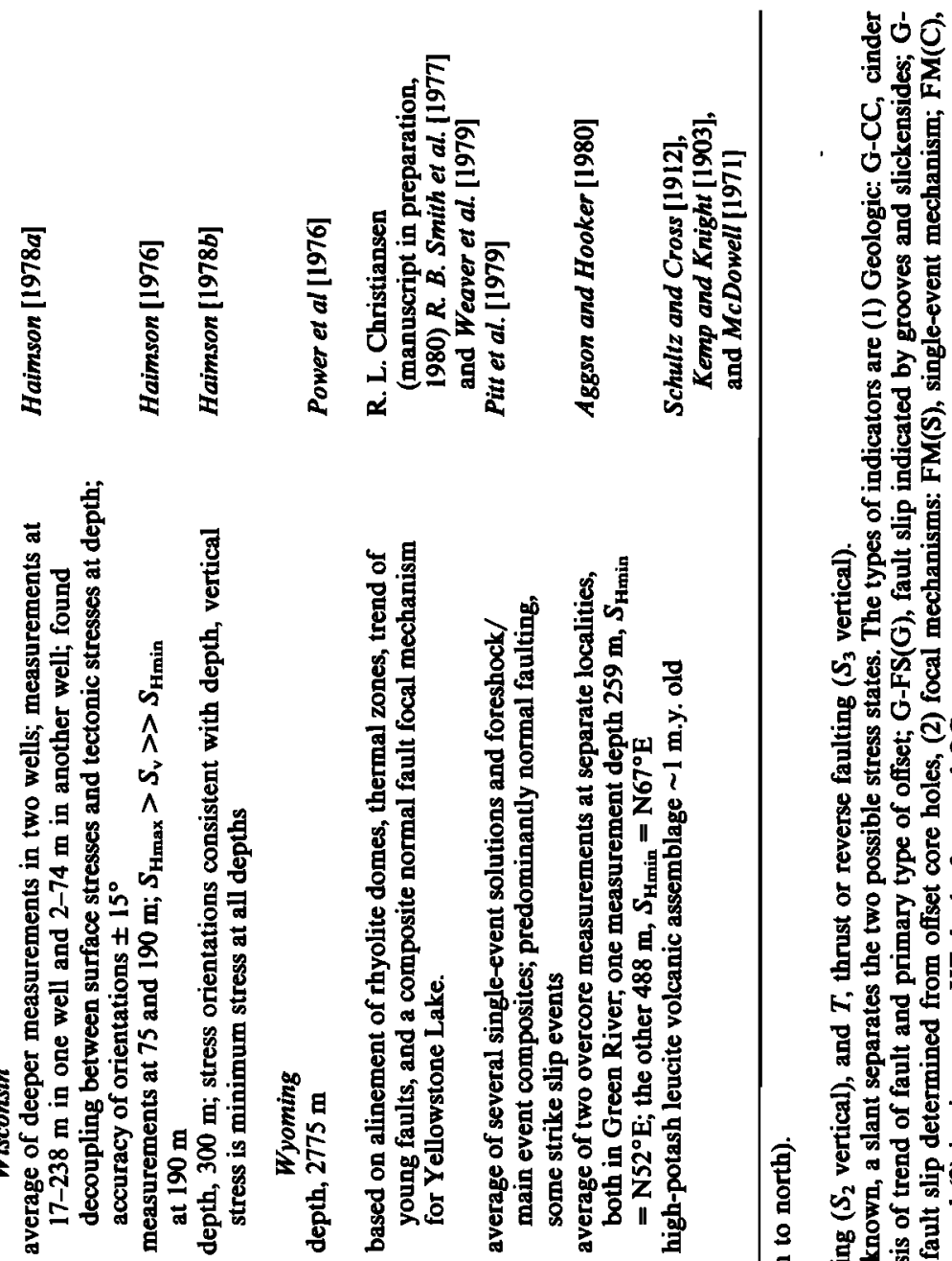

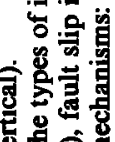

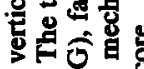

5n

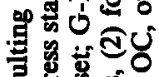

尊

政

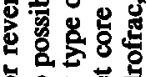

要要

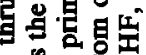

is

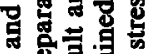

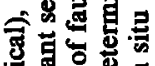

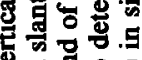

实

vis

2.0

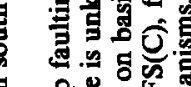

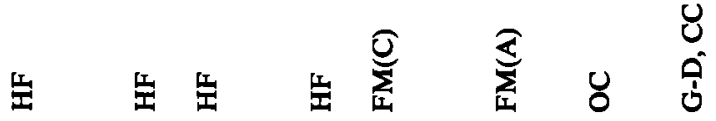

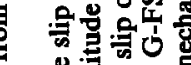

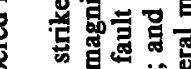

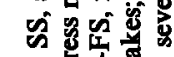

$+y+\delta z \frac{\hbar}{z} \tilde{z}$

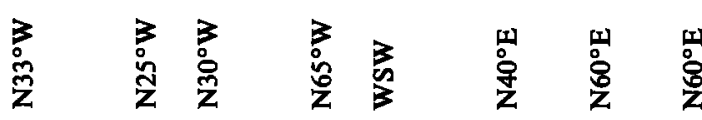

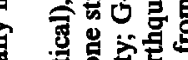

s:

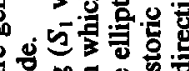

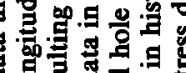

o

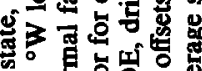

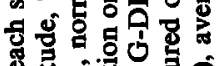

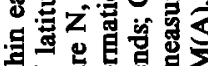

z

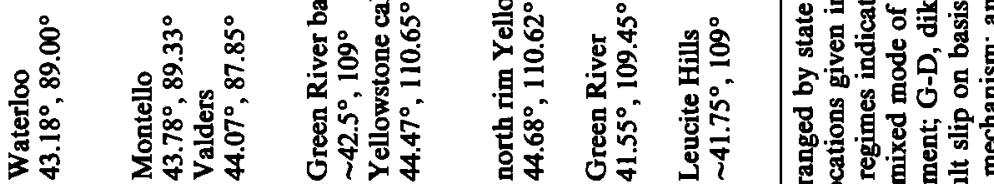

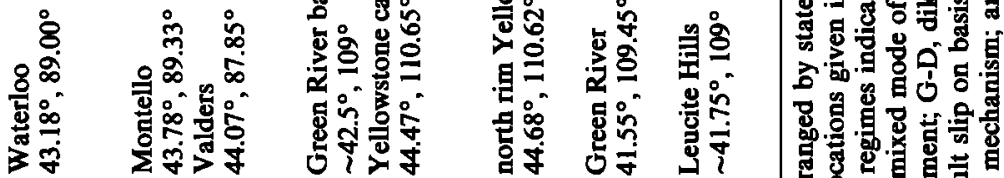

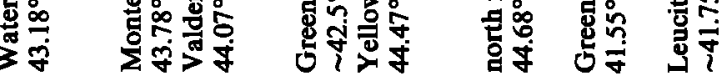

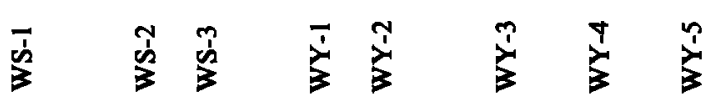


$T$ axes were considered for the present compilation. Elsewhere in the United States, coverage is largely from single event solutions and, less frequently, from microearthquake composite solutions. In the central and eastern United States, most of the focal mechanisms used [from Herrmann, 1979] are constrained by both body wave and surface wave solutions.

As discussed earlier, we have assumed that two of the principal stress directions are horizontal and that the third is vertical. Thus only horizontal stress axes, as inferred from the fault plane solutions, that have plunges of less than $20^{\circ}$ were considered. A few rare exceptions of $T$ axes with plunges up to $30^{\circ}$ were included where the consistency of the stress orientation with surrounding data justified their inclusion. Information on the plunges of $P$ and $T$ axes is listed in Table 1 .

Compilations of fault plane solutions for the western United States by $R$. B. Smith and A. G. Lindh [1978], in the Rio Grande rift by Sanford et al. [1979] and for the eastern United States by Sbar and Sykes [1977] and Herrmann [1979] were the primary data sources in the present study. However, we attempted, whenever possible, to return to the original references and reject poorly constrained mechanisms. Further details of particular focal mechanisms are discussed in the sections on individual stress provinces.

\section{In Situ Stress Measurements}

The third stress indicator used in this study was the direct determinations of both the orientation and magnitude of tectonic stress at depth. We primarily considered measurements made by the hydraulic fracturing ('hydrofrac') technique, currently the only method of measuring stress at large distances from free surfaces. The technique consists of hydraulically isolating a section of a well or borehole (by means of inflatable rubber packers) and pressurizing the isolated section until a tensile fracture is induced at the well bore. If the borehole parallels one principal stress (usually the lithostat), a vertical fracture will form at the azimuth of the greatest horizontal principal stress, which generally can be determined to better than $\pm 10^{\circ}$. However, repeated measurements at different depth intervals within a given borehole generally have a range of $\pm 15^{\circ}$, probably a more accurate estimate of the reliability of the method.

From the pressure-time history of hydraulic fracture formation and extension, the magnitudes of both horizontal principal stresses can be computed. Assessing the accuracy of the stress magnitudes determined from any given measurement can be quite difficult and requires detailed knowledge of the pressure-time data and well conditions. Typically, the least horizontal principal stress can be determined with greater accuracy than the greatest because determination of the greatest principal horizontal stress requires an assumption of linear elasticity around the well bore. The hydrofrac technique was described in detail by Haimson and Fairhurst [1970] and interpretation of hydrofrac data was discussed at length by $M$. $D$. Zoback et al. [1977, 1980b] and McGarr and Gay [1978]. Compilations of hydrofrac stress measurements by Haimson [1977b] and McGarr and Gay [1978] were used extensively in this study.

Several other widely used stress measurement methods can be broadly characterized as stress relief techniques. These methods are all basically passive and involve measurement of the strain or displacement that occurs when the ambient stress field is relieved by techniques such as overcoring. The most significant drawbacks of stress relief techniques are that they typically cannot be used more than several tens of meters from free surfaces and that they seem to be extremely sensitive to local inhomogeneities in the rock. McGarr and Gay [1978] gave an excellent review of these techniques and discussed many of the inherent experimental difficulties.

Stress measurements made within several tens of meters of the surface have not been included in this study. Such measurements are particularly susceptible to the effects of weathering, erosion, and deglaciation. Also, nearby surface fractures and joints can apparently act to decouple surface rocks from the tectonic stress field [Haimson, 1978a; M. D. Zoback and J. C. Roller, 1979].

\section{Stress MaP of The ConTerminous UnITEd States}

Utilizing the three types of principal stress indicators discussed above, we have assembled two maps of horizontal stress orientations for the conterminous United States. The data are numbered by states (Table 1) and presented on a map of physiographic provinces of the United States in Plates 1 and 2. Figure 1 names the physiographic provinces of the United States [after Fenneman, 1946] for reference. In Plate 1 we show the least principal horizontal stress direction and the type of stress indicator used in the determination; sites where more than one type of stress indicator was used are designated by multiple symbols. A description of each site is listed in Table 1. We chose to present only the least principal horizontal stress in Plate 1 because of the consistency of this principal axis throughout a broad region of the western United States that includes the Basin and Range province, the Sierra Nevada, and the area along the San Andreas fault. In regions of active thrust or reverse faulting, the least principal horizontal stress shown is actually the intermediate principal stress $S_{2}$. Plate 2 presents the stress data in a manner to depict the relative magnitude of the horizontal and vertical stresses with the stress provinces we have defined to indicate regions in which the relative magnitude and orientation of the stress field is fairly uniform.

As shown in Plate 2, the United States can be divided into stress provinces which correspond, in a general way, with the physiographic provinces. In the following sections the individual stress provinces are discussed in detail. First, a few important general observations that can be made from Plates 1 and $2:$

1. In regions where more than one type of stress indicator was available a good correspondence exists between the results of the different methods, generally well within the estimated accuracy of individual determinations.

2. The intraplate stress field for that part of the North American plate represented by the conterminous United States is not uniform. Variations in the relative magnitude and orientation of the principal stresses have wavelengths which range from 100 to $3000 \mathrm{~km}$. The western United States, a site of active tectonism characterized by a high level of seismicity and generally high heat flow, is marked by a complex pattern of stress. Even in the eastern United States, despite its relative tectonic quiescence, major variations in principal stress orientations appear to exist.

3. Broad regions of the crust (with linear dimensions as large as $3000 \mathrm{~km}$ in the midcontinent area) can be characterized by a relatively uniform stress field (within $\pm 10^{\circ}-20^{\circ}$ ).

4. Large changes in orientation of the principal stress field (up to $90^{\circ}$ ) can occur laterally over short distances ( $\leq$ about 75 $\mathrm{km}$ ). These changes may be due to an actual rotation of the 


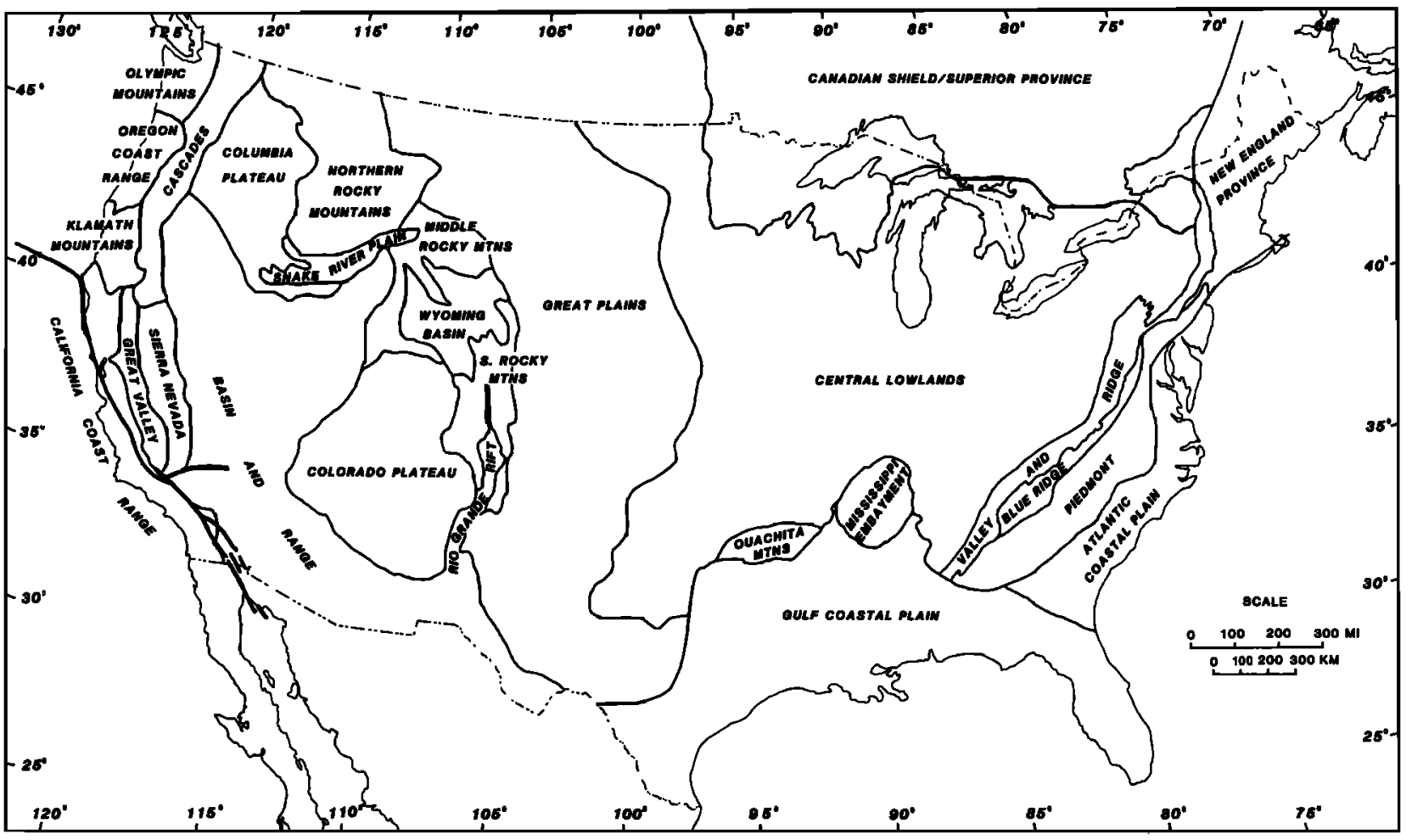

Fig. 1. Index map with names of physiographic provinces shown on Plates 1 and 2.

principal stress field or a rapid change in the relative magnitude of principal stresses.

\section{Stress Provinces: WeStern UNITED STATES}

The western United States represents a broad area of active tectonism, as evidenced by the high level of seismicity (Figure 2) and the generally high heat flow (Figure 6). Plate 2 indicates our interpretations of the various stress provinces in that region. Where the data coverage is somewhat sparse, we have also relied on the seismicity map (Figure 2) as well as on Howard et al.'s [1978] map of young faults in the United States (along with their accompanying discussion) to delineate the stress provinces. As might be expected, in areas of good data coverage a good general correspondence is apparent between the provinces defined by Howard et al., on the basis of patterns and styles of Cenozoic faulting, and the provinces defined by stress magnitudes and orientations.

\section{Pacific Northwest}

The Pacific Northwest stress province includes the only active andesitic volcanic chain within the conterminous United States (the Cascades); it also includes the Pacific coastal ranges in Washington and Oregon and the 'back arc' region, the Columbia Plateau. The following discussion draws heavily from summaries of the regional stresses and tectonic setting of the Pacific Northwest by Crosson [1972], Davis [1977], and $R$. B. Smith [1977, 1978].

The least principal horizontal stress direction throughout this province averages about east-west; the consistent stress axis, however, appears to be alined with the greatest principal stress $S_{1}$, a horizontal N-S compression. Focal mechanisms indicate both strike slip and thrust faulting; a predominance of thrust mechanisms suggests that the vertical stress $S_{\mathrm{v}}$ may, in general, be the least principal stress $S_{3}$. The relative magni- tudes of the principal stress can be represented in the following manner:

$$
S_{1}>S_{2}>S_{3}
$$

or

$$
S_{\mathrm{N}-\mathrm{s}}>S_{\mathrm{E}-\mathrm{W}}>S_{\mathrm{v}}
$$

Crosson [1972] has suggested that the occurrence of both strike slip and thrust earthquakes may result from a more rapid increase with depth of the vertical stress relative to the horizontal stresses. Thus thrust faulting ( $S_{\mathrm{v}}$, least principal stress) would be favored at shallow depths, whereas strike slip faulting ( $S_{\mathrm{v}}$, intermediate principal stress) would be expected at greater depths.

Two distinct areas of relatively active tectonism within the Pacific Northwest province demonstrate contrasting styles of deformation resulting from the N-S compression. The Puget Sound-Olympic Peninsula area is the site of several large historical earthquakes (including both upper crustal and mantle-60- to $70-\mathrm{km}$ depth-events) and also of numerous Quaternary scarps showing strike slip and reverse faulting. Farther east in the central Columbia Plateau, a largely aseismic region, folding along east-west trending axes that began in late Tertiary time have continued throughout the Quaternary [cf. Davis, 1977, for references]. Inclusion of the Cascades andesitic volcanic chain in the Pacific Northwest compressional stress province is consistent with observations of a state of compression within island arcs behind which there is no active extension [Nakamura et al., 1978]. This compression is generally parallel to the direction of convergence which, as discussed below, is not the case in the Pacific Northwest.

The predominance of relative N-S compression within the Pacific Northwest distinguishes this stress province from the 


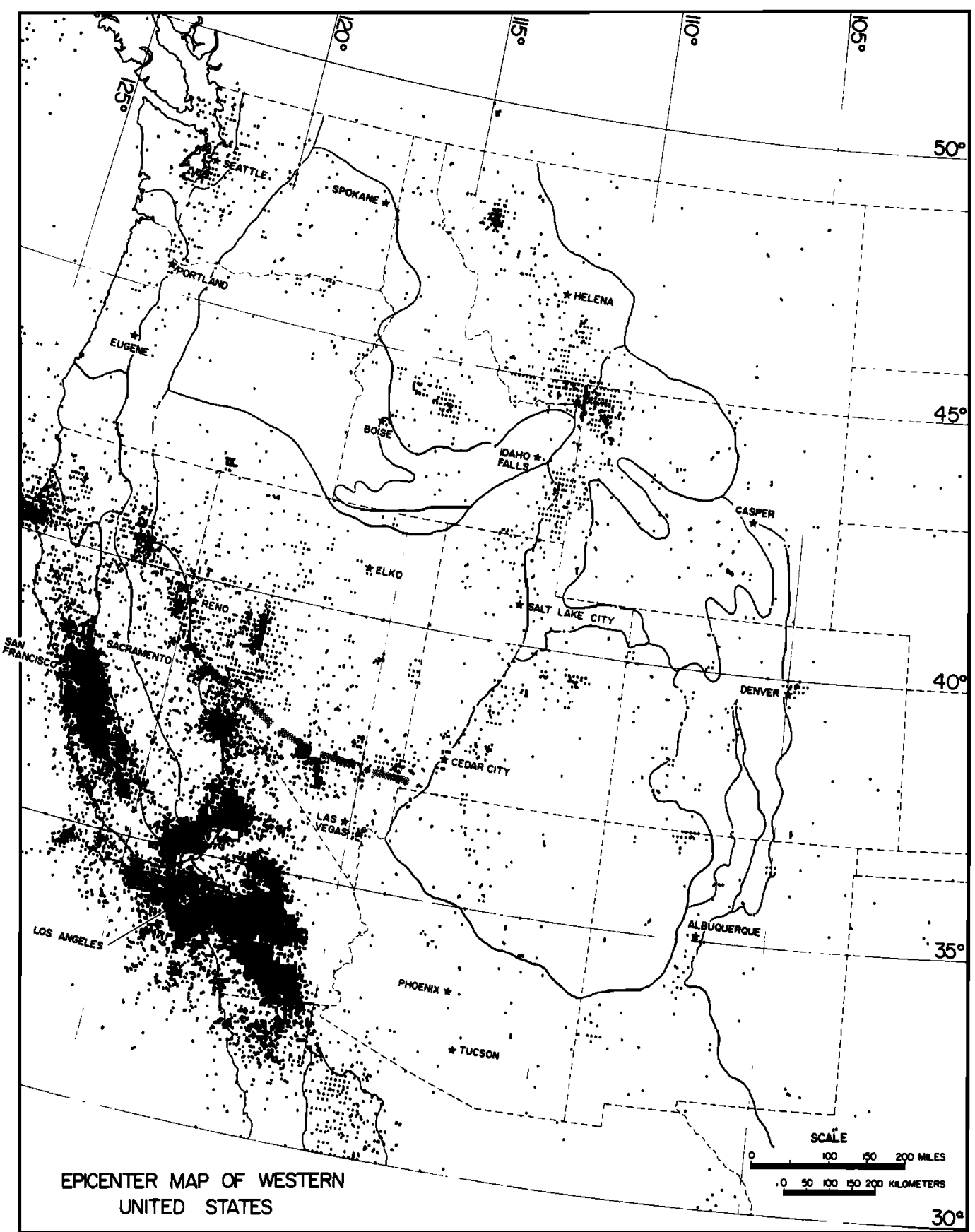

Fig. 2. Seismicity map of western United States [from $R$. B. Smith, 1978]. Data set primarily includes instrumentally located earthquakes from 1950 to 1972, but some earlier earthquakes are also incorporated. Events are not differentiated by magnitude. In California, minimum magnitude earthquakes plotted are $M \sim 1$, and for rest of the western United States, $M \sim 3$. Outlines of physiographic provinces have been added. Dashed line in the southern part of northern Basin and Range marks approximate eastward extent of pure strike slip fault plane solutions in that region.

Basin and Range province to the south, which is characterized by WNW-ESE extensional tectonics. An approximately eastwest zone at about $44.5^{\circ} \mathrm{N}$ latitude (roughly the northernmost extent of basin-range-type normal faulting) separates these two provinces. $R$. B. Smith [1978] identified this east-west zone as a relatively aseismic intraplate boundary that may extend eastward either to the edge of the aseismic Snake River plain or to a zone of earthquakes trending northwest through the Idaho batholith (Figure 2). Blackwell [1978] has shown that an east-west trending thermal energy boundary coincides with this stress boundary.

\section{San Andreas}

The most seismically active region within the United States is the California coast area, which includes the San Andreas fault system. The San Andreas and subsidiary subparallel faults mark a major right-lateral transform plate boundary between the Pacific and North American plates.

Least principal horizontal stresses, which are relatively uniform throughout the province, trend E-W to WNW-ESE, but the regional pattern of stress can be complicated locally by an often complex geometry of interacting faults [e.g., Pavoni, 
1979; Ellsworth and Marks, 1980]. The generally strike slip style of deformation indicates that this horizontal stress direction does in fact correspond to $S_{3}$. The relative magnitudes of the stresses are thus

$$
S_{1}>S_{2}>S_{3}
$$

or

$$
S_{-\mathrm{N}-\mathrm{S}}>S_{\mathrm{v}}>S_{\sim \mathrm{E}-\mathrm{W}}
$$

Exceptions to this general style of strike slip deformation occur throughout the province on faults striking at large angles to the NW-SE San Andreas trend. Motion on these faults appears consistent with the regional stress field, i.e., thrust or reverse faulting on approximately east-west trending faults and normal displacements on approximately north-south faults. The consistency of the $P$ and $T$ axes for slip on these faults with widely varying trends reinforces the use of average $P$ and $T$ directions as reliable indicators of the principal stress directions.

The most obvious example of a change in deformational style along the San Andreas occurs where the trend of the fault markedly changes in the Big Bend area of southern California. The post-Miocene to present development of the Transverse Ranges is dramatic evidence of crustal shortening in that area [Jahns, 1973]. There, the fault system trends nearly east-west, and the primary mode of deformation is folding and thrust or reverse faulting. This large-scale thrust and reverse faulting requires a vertical least principal stress as opposed to the regional horizontal orientation of $S_{3}$. This apparent exchange (or rotation) of the principal stresses can easily be explained if in that area the least principal horizontal stress and the vertical stress are approximately equal in magnitude.

Compressional features outside the Big Bend area include Neogene anticlines subparallel to the San Andreas fault [e.g., Harding, 1976; Wilcox et al., 1973; Blake et al., 1978] and thrust type focal plane mechanisms in the Coast Ranges (see CA-9 and CA-10, Table 1). These features provide evidence that the San Andreas province is not in pure shear, as a component of compression is acting normal to the fault.

Crustal shortening in the Big Bend area can be thought of as resulting from the large left-stepping shift in the San Andreas fault. Similarly, near en echelon offsets between active strands of the fault, a change in deformational style can be expected. The geometry of these offsets requires local crustal shortening in the case of left-stepping offsets and local crustal extension in the case of right-stepping offsets. Hill [1977] has presented a model to explain the style of deformation and extension within right-stepping offsets. This model was tested with data from two localities along the San Andreas fault [Weaver and Hill, 1979]. Active extension in one of these localities (Salton Trough) is strongly suggested by normal fault scarps [Sharp, 1976], high heat flow, and a few normal fault focal mechanisms within the zone of offset. Weaver and Hill also reported that the $T$ axes for fault plane solutions from earthquakes along the offset fault strands and within the offset volume are nearly invariant. This result suggests that the direction of $S_{3}$ is not significantly perturbed from its regional orientation in the vicinity of the offsets. The occurrence of normal faulting, however, suggests that locally, $S_{1}$ is vertical rather than horizontal.

Also included in the San Andreas subprovince is the leftlateral, Garlock fault and the Mojave block. During middle to late Miocene time the Mojave block was deformed primarily by normal faulting along NW trending faults [Dibblee, 1967]. Current tectonism in this block, as evidenced by recent seismicity, faulting, geodetic data, and generally subdued topography, indicates primarily right-lateral strike slip motion on these NW trending faults and justifies its inclusion as part of the San Andreas province.

The Mojave block is separated from the Sierra Nevada and southwestern Great Basin to the north by the ENE trending Garlock fault. The Garlock fault has been described as a major left-lateral fault conjugate to the San Andreas system [M. L. Hill and T. W. Dibblee, 1953] and also as a major continental transform accommodating extension in the Basin and Range to the north in relation to the Mojave block; increasing fault offsets on the Garlock to the west support the transform fault interpretation [Davis and Burchfiel, 1973]. Furthermore, westward shifting of the block to the north of the Garlock fault due to this extension has probably contributed to the westward bending or deflection of the San Andreas fault where the two faults meet [Davis and Burchfiel, 1973]. Limited information on extension directions on normal faults north of the Mojave block, however, indicate that the horizontal displacement may not parallel the Garlock fault as would be required for true transform-style faulting.

\section{Sierra Nevada}

The Sierra Nevada marks a transition from the primarily strike slip deformation along the San Andreas fault to the extensional tectonics of the Basin and Range province. Accordingly, several lines of evidence on active tectonics of the Sierra indicate both strike slip and normal faulting. Examples of pure strike slip deformation include the Kern Canyon fault, a major ( $\sim 80 \mathrm{~km}$ long) $\mathrm{N}-\mathrm{S}$ trending right-lateral fault active throughout late Tertiary time [Moore and duBray, 1978] and the microfaulting discussed below. However, the extensional tectonics of the Basin and Range province, including normal faulting and high heat flow, extends $50-100 \mathrm{~km}$ into the eastern Sierra; Lake Tahoe, for example, is a down-dropped basin like those to the east in Nevada. Also, major earthquakes with both strike slip (1966 Truckee earthquake, CA-31) and normal (1975 Oroville earthquake, CA-32) faulting mechanisms have been recorded in the northern Sierra.

Least principal horizontal stress directions trend WNWESE to E-W in the northern Sierra but appear gradually to rotate until they are trending approximately NW-SE in the southern Sierra. Stress orientations from different types of indicators agree fairly well within the Sierra Nevada block; furthermore, least horizontal stress orientations agree well with those in the surrounding San Andreas and Basin and Range provinces.

The existence of contemporaneous strike slip and normal faulting in the Sierra Nevada suggests that the magnitudes of the vertical and greatest principal horizontal stresses are nearly equal and can readily exchange. The principal stress field probably has the form

$$
S_{1} \simeq S_{2} \gg S_{3}
$$

or

$$
S_{\mathrm{NNE}} \simeq S_{\mathrm{v}} \gg S_{\mathrm{WNW}}
$$

Thus local variations in the relative magnitudes of $S_{\mathrm{NNE}}$ and $S_{v}$ and/or local faulting trends may determine whether strike slip or normal faulting occurs. 
Many of the least principal stress directions in the Sierra Nevada block (CA 19-22, 24-25, and 28-30, Table 1) come from a unique study by Lockwood and Moore [1979] of offsets on near-vertical strike slip microfaults. These microfaults are oriented in two conjugate sets, a north to northeast striking set that shows right-lateral offset, and an east to northeast striking set that shows left-lateral offset. The age of this microfaulting is poorly established; the faults formed after solidification of the youngest plutons in the Sierra Nevada $(79$ m.y. B.P.) and are known to cut a late Miocene volcanic dike in one area. A maximum horizontal extensional-strain direction (assumed to be alined regionally with the least principal stress) was taken as the bisector of the obtuse angle of the average microfault trends. A pure shear constant volume analysis based on a detailed study of microfault offsets in one locality indicates that the true maximum extensional-strain direction differs by only $6^{\circ}$ from the bisector.

For the bisector analysis used by Lockwood and Moore [1979] to be valid, the fault sets must be true conjugates, and the strain must be small $(<10 \%)$ and distributed on both sets. Absence of offset on some microfaults and filling by vein minerals such as quartz and epidote suggest a tensile origin for the microfaults, many of which were reactivated in shear after a change in regional stress orientation. In addition, both the aerial photo lineation analysis and the microfault orientations reported by Lockwood and Moore [1979] indicate that the east to northeast striking (left-lateral) set predominates and suggest that the strain may be very unevenly divided between the two sets. Thus the trends of the microfaults, while indicative of the regional stress field, may not be very precisely oriented with respect to that stress field (perhaps only within $\pm 25^{\circ}$ ). However, parallelism between the least principal stress orientations inferred from these microfaults and those in the surrounding San Andreas and Basin and Range provinces suggests that these faults are young features recording deformation in a stress field similar to the modern one.

\section{Basin and Range-Rio Grande Rift}

The Basin and Range province is a region of active crustal spreading characterized by high regional elevation, thin crust (average thickness $\sim 30 \mathrm{~km}$ ), and high heat flow [Thompson and Burke, 1974]. The Basin and Range-Rio Grande rift stress province discussed here extends from the Sierra Nevada eastward to well within the Colorado Plateau physiographic province and around the south margin of the Colorado Plateau and northward into the Rio Grande rift proper in New Mexico. The southern Basin and Range has been included with the currently more tectonically active northern Basin and Range on the basis of generally consistent least principal stress orientations and regionally high heat flow, the mean value of which is similar to the northern Basin and Range mean of 2.1 heat flow units (HFU) $\left(\mu \mathrm{cal} / \mathrm{cm}^{2} / \mathrm{s}=41.9\right.$ $\mathrm{mW} / \mathrm{m}^{2}$ ) [Lachenbruch and Sass, 1977, U.S. Geological Survey, unpublished data, 1979]. Thus, although a large difference in strain rate between the two regions has persisted throughout Quaternary time and possibly longer (on the basis of young fault scarps mapped by Howard et al. [1978]), the regional stress field appears to be uniform. The Rio Grande rift is often referred to as a distinct continental rift [e.g., Bridwell, 1976]; however, similarities in geophysical characteristics and tectonic style [cf. Cordell, 1978; Thompson and Zoback, 1979] warrant its inclusion in the same stress province as the Basin and Range.
Seismicity extends throughout the province (see Figure 2); however, it is most concentrated along the margins of the northern Basin and Range, in the N-S trending Nevada seismic zone on the west and the Intermountain Seismic Belt on the east [Sbar et al., 1972]. A roughly north trending belt of historical earthquakes of magnitude $>7$ occurs within the $\mathrm{Ne}$ vada Seismic Belt [Ryall et al., 1966]. However, as Slemmons [1967] pointed out, this pattern of modern seismicity is not a good indicator of tectonic activity in the recent past because Quaternary scarps are widespread throughout the interior northern Basin and Range.

Least principal stress orientations are generally WNW-ESE throughout the Basin and Range-Rio Grande rift province. Exceptions to this general pattern occur in southern Nevada, where the data seem to indicate a more NW-SE least principal stress direction, and along the Wasatch fault in Utah, where modern crustal extension appears to be more in an E-W direction. Possible explanations of these regional variations are discussed later in the source of stress section.

The primary mode of deformation within the Basin and Range-Rio Grande rift is normal faulting with a consistent approximately WNW direction of opening, indicating a stress field of the form

$$
S_{1}>S_{2} \gg S_{3}
$$

or

$$
S_{\mathrm{v}}>S_{\mathrm{NNE}} \gg S_{\mathrm{WNW}}
$$

A detailed discussion of the relative magnitudes of these principal stresses, constrained by an analysis of slip directions and pattern of faulting in northern Nevada, has recently been presented by M. L. Zoback and M. D. Zoback [1980].

A consistent direction of extension throughout much of the Basin and Range-Rio Grande rift province may be inferred from the relatively uniform pattern of horizontal displacements, despite the complex geometry of the fault blocks. A necessary result of this uniform extension is oblique slip normal faulting (i.e., both strike slip and dip slip components of motion) on faults that are not perpendicular to the least principal stress direction. Examples of this oblique slip style of faulting are abundant throughout the province. As has been noted by many workers [e.g., Slemmons, 1967; Wright, 1976], the geometry of the pattern of displacements requires purely dip slip motion on approximately NNE trending faults, a component of right-lateral slip on faults trending $\mathrm{N}$ to $\mathrm{NW}$, and a componet of left-lateral slip on faults trending NE to ENE. Thus modern components of right-lateral strike slip should be expected on the generally NW trending faults in the southern Basin and Range (in contrast to nearly purely dip slip motion expected on the NNE striking faults that characterize much of the northern Basin and Range). Scanty data on fault slip in the southern Basin and Range and Rio Grande rift (AZ-7; MX-1; NM-6, 16, 27; Table 1) confirm this expectation.

It is important to point out that these oblique slip faults are basically normal, not strike slip, faults. The oblique slip arises as the major crustal blocks attempt to extend in roughly the least principal stress direction regardless of the trend of the fault.

Although most of the Basin and Range province is characterized by normal faulting, the stress transition (from strike slip deformation along the San Andreas fault) evident in the Sierra Nevada extends into the westernmost northern Basin 
and Range, the Walker Lane-Las Vegas shear zone region, where examples of normal, pure strike slip, and oblique slip faults can be found [cf. Slemmons et al. [1979] for a detailed discussion of the rate and style of deformation in this region]. Earthquake focal mechanisms in this region indicate consistent $\boldsymbol{T}$ axes regardless of the style of faulting [e.g., Hamilton and Healy, 1969]. This zone of stress transition, as inferred from the distribution of purely strike slip fault plane solutions, extends roughly $200-250 \mathrm{~km}$ eastward into the Basin and Range (see Figure 2). The relative magnitudes of the principal stresses within this region, as inferred from the coexistence of normal and strike slip faulting, are

$$
\begin{gathered}
S_{1} \simeq S_{2} \gg S_{3} \\
S_{\mathrm{v}} \simeq S_{\mathrm{NNE}} \gg S_{\mathrm{WNW}}
\end{gathered}
$$

Thus, although the relative magnitudes of $S_{v}$ and $S_{\mathrm{NNE}}$ can interchange locally, the $S_{3}$ direction (WNW) remains invariant.

The available data indicate a rather abrupt transition in stress orientation between the Rio Grande rift province and the southern Great Plains, occurring over $<75 \mathrm{~km}$ in one area (compare NM-26 and NM-27). The Basin and Range-Rio Grande rift stress field continues well into the physiographic Colorado Plateau consistent with high heat flow, faulting, and recent volcanism along the plateau margins [Thompson and Zoback, 1979]. The nature of the stress transition between these two provinces is discussed in detail below.

\section{Colorado Plateau Interior}

The Colorado Plateau stress province is distinctly smaller than the Colorado Plateau physiographic province (see Plate 2). The state of stress within the plateau interior, discussed in detail by Thompson and Zoback [1979], is briefly summarized below.

The Colorado Plateau interior is characterized by roughly NNE-SSW least principal horizontal stress direction, perpendicular to the general WNW-ESE least principal stress direction in the surrounding Basin and Range-Rio Grande rift province. The data also appear to support a radial distribution of least principal horizontal stress orientations perpendicular to the plateau margins. The preferred interpretation of a uniform NNE least principal horizontal stress within the Colorado Plateau interior comes from data along the northern edge of the plateau across which there are no known major geologic, topographic, or geophysical contrasts.

The absence of major faulting or seismicity within the plateau interior could be interpreted to indicate generally low differential stresses. Apparently consistent with this interpretation, in situ stress measurements (at $\sim 0.5 \mathrm{~km}$ depth) in the Piceance Basin (CO-3) in northwestern Colorado indicate that all three principal stresses are approximately equal to the lithostat [Bredehoeft et al., 1976]; alternatively, these low deviatoric stresses may simply be due to the shallow depth and rather weak rock within the basin. The occurrence of both strike slip and thrust focal mechanisms clearly demonstrates the existence of high horizontal stresses locally exceeding the lithostat and indicates a compressional stress regime of the form

$$
S_{1}>S_{2} \simeq S_{3}
$$

or

$$
S_{\mathrm{WNW}}>S_{\mathrm{NNE}} \simeq S_{\mathrm{v}}
$$

The Basin and Range-Rio Grande rift extensional stress field appears to continue $100-200 \mathrm{~km}$ into the plateau proper (cf. Plate 2), consistent, as mentioned above, with high heat flow, normal faulting, and recent volcanism along the plateau margins [Thompson and Zoback, 1979]. The $90^{\circ}$ change in stress orientation between the Basin and Range Colorado Plateau interior provinces occurs locally over a lateral distance of $<50 \mathrm{~km}$ (cf. UT-8, 9, 10, 11, 12, 13 and NM-12, 13, 14, 15). Data in central Arizona along with a reverse fault focal mechanism at $35.16^{\circ} \mathrm{N}, 112.15^{\circ} \mathrm{W}$ ([Brumbaugh, 1980] not included on the maps because of the late data at which we became aware of it) suggest a broader stress transition, up to $150 \mathrm{~km}$ wide, in which all three stresses are approximately equal in magnitude. This is suggested by the occurrence of both WNW and NNE trending dikes and cinder cone alinements (AZ-7, 8, 10), as well as focal mechanisms for two events $70 \mathrm{~km}$ apart which imply both normal (AZ-14) and reverse [Brumbaugh, 1980] faulting on NW trending planes. The observed contrasting styles of deformation in this $150 \mathrm{~km}$ wide zone can be explained by minor local variations in magnitude of one of the principal stresses and, also, possibly by the influence of local, preexisting structural grain.

\section{Snake River Plain-Yellowstone}

The Snake River plain is a downwarped volcanic plain formed during the past $17 \mathrm{~m}$.y. by a steady northeastward migration of silicic volcanism and subsequent semicontinuous outpourings of basalt along its older (western) reaches [Armstrong et al., 1975]. The site of modern silicic volcanism on the plain is the Yellowstone caldera. The Snake River plain-Yellowstone trend has been considered by some workers to be a propagating lithospheric crack (possibly alined with a preexisting zone of weakness) [e.g., $R$. B. Smith et al., 1974b; Eaton et al., 1975] and by others to mark an active hot spot trace [e.g., Morgan, 1972; Suppe et al., 1975]. An inversion of relative plate motions to a mantle reference frame indicates that the absolute motion of the North American plate for the last $10 \mathrm{~m} . \mathrm{y}$. is well represented by the Snake River plain-Yellowstone trend [Minster and Jordan, 1978].

The Snake River plain is largely aseismic with the exception of some shallow ( $<6 \mathrm{~km}$ ) earthquakes at Yellowstone. The only data available on principal stress orientations on the plain (with the exception of a composite focal mechanism within the caldera) are geologic and come from numerous young (<1 m.y. B.P.) feeder vents which cut across the plain. As Weaver et al. [1979] noted, these indicators suggest a roughly NE-SW least principal stress direction, parallel to the axis of the Snake River plain, not perpendicular, as suggested by Hamilton and Myers [1966]. This extension along the axis of the plain requires transform style of faulting along the margins of the plain, particularly to the north.

The enormous volume of volcanism on the Snake River plain and related normal faulting indicate extensional tectonics. Thus the stress field on the Snake River plain can be characterized by

$$
S_{1}>S_{2}>S_{3}
$$

or

$$
S_{v}>S_{\sim \mathrm{NW}}>S_{\sim \mathrm{NE}}
$$

The direction of the least principal stress on the Snake River plain appears oblique to that in the Basin and Range province 
directly to the south, where the least principal stress direction trends WNW-ESE to E-W. This distinction in trend and its unique Late Cenozoic volcanic history are the justification for making the Snake River plain a separate stress province.

The area immediately surrounding the Yellowstone caldera is marked by a high level of seismicity (see Figure 2). Detailed focal mechanism studies in the area north of the caldera by Trimble and Smith [1975], R. B. Smith et al. [1977], and Pitt et al. [1979] further document an approximately $90^{\circ}$ rotation of the least principal horizontal stress direction between the Snake River plain and the area to the north first noted by Freidline et al. [1976]. This rotation occurs over a lateral distance of only $100 \mathrm{~km}$.

\section{Hebgen Lake-Centennial Valley}

As evidenced by focal mechanisms and recent faulting, the Hebgen Lake-Centennial Valley stress province is characterized by N-S extension. The south boundary of this province near Yellowstone, as discussed above, is marked by an abrupt $90^{\circ}$ rotation of the least principal stress direction that occurs over a lateral distance of $<100 \mathrm{~km}$. The northward extent of this province is undefined, and available focal mechanism data, discussed in detail by Freidline et al. [1976], suggest a broad zone of transition in which $T$ axes again rotate $90^{\circ}$ (from N-S to E-W) from southern to northern Montana. We have drawn a tentative northern boundary for the province on the basis of changes in the trends of faulting (from approximately E-W to NW-SE) to the north. The province is also tentatively extended to the west to include a composite focal mechanism in the Idaho batholith (ID-5) that indicates E-W trending normal faulting.

\section{Northern Rocky Mountains}

The Northern Rocky Mountains stress province is characterized by normal and strike slip faulting along generally NWSE trends that probably began in early Miocene time and continues to the present, as evidenced by Quaternary scarps [Freidline et al., 1976; Howard et al., 1978; Reynolds, 1979]. Above average heat flow [Lachenbruch and Sass, 1977], the occurrence of hot springs [e.g., Muffer, 1979, Map 1], high regional elevation [e.g., Reynolds, 1979], and moderately high seismicity [e.g., R. B. Smith and M. L. Sbar, 1974] are all suggestive of active extensional tectonism in this province and distinguishes it from the Pacific Northwest province to the west, which appears to be dominated by N-S compressional tectonics.

The exact boundaries of the Northern Rocky Mountains and, in fact, even the existence of such a province are difficult to define from the available stress data. As discussed above, the small, poorly defined Hebgen Lake-Centennial Valley stress province bounds the Northern Rocky Mountains province to the south. The positions of the eastern and western boundaries are based on the extent of young NW trending normal faulting shown on Howard et al.'s [1978] map and are consistent with boundaries of extensional tectonism delineated by Reynolds [1979]. Three in situ stress measurements in northern Idaho along the western boundary are completely contradictory both in orientations and relative magnitudes of principal stress; two are independent strain relief measurements in mines $3 \mathrm{~km}$ apart (ID-7) which are inconsistent with one another, and both disagree with a nearby hydrofrac measurement (ID-6). Focal mechanisms near the eastern bound- ary of the province (MT-4, 5) are also somewhat contradictory. The northern boundary remains undefined by the present data.

In general, the stress field for the Northern Rocky Mountain stress province appears to be characterized by NE-SW to E-W least principal stress orientations, consistent with the prominent $\mathbf{N}$ to NW trending normal faulting. The occurrence of both strike slip and normal focal mechanisms with locally consistent $T$ axes led Freidline et al. [1976] to suggest that the greatest and intermediate principal stresses $\left(S_{\mathrm{v}}\right.$ and $S_{\mathrm{N} \text {-StoNW-SE }}$ may be approximately equal in magnitude. The generally E-W to NE-SW extension in the Northern Rocky Mountains appears to represent a northward continuation of basin-range structure interrupted by the Snake River plain and with possibly a slight clockwise rotation of the extension direction.

\section{Southern Great Plains}

The southern Great Plains area is characterized by a very uniform state of stress in which the least principal horizontal stress direction to NNE-SSW. The data come from two primary sources: (1) alinement of post-5 m.y. volcanic feeders in the Raton-Clayton volcanic field of northern New Mexico and (2) fracture orientations obtained from hydraulically fractured wells in the Permian basin of western Texas [Zemanek et al., 1970]. An earthquake focal mechanism and in situ stress measurements in eastern Colorado show consistent orientations. Despite the similar least principal horizontal stress orientations in the southern Great Plains and in the plateau interior, the probable extensional regime (as inferred from earthquake focal mechanisms and basaltic volcanism) distinguishes the southern Great Plains from the Colorado Plateau interior and Midcontinent provinces which are dominated by compressional stress regimes. The least principal horizontal stress directions to the southern Great Plains province are generally oblique to those in the Midcontinent stress province; however, in west-central Texas the data suggest a counterclockwise rotation of the stress field from west to east to directions more consonant with midcontinent stress orientations (Plates 1 and 2). The easternmost site of this group of data (TX-15) is a normal fault focal mechanism, suggesting that the boundary with the compression-dominated Midcontinent stress province must lie further to the east.

Two important characteristics of the stress field in the southern Great Plains province are (1) its uniformity $\left(\sim \pm 15^{\circ}\right.$, which is within the range of estimated accuracy of the different stress indicators) over a region with a north-south extent of at least $1100 \mathrm{~km}$ and (2) an abrupt transition in stress orientation in relation to the Rio Grande rift that occurs locally over a lateral distance of $<50 \mathrm{~km}$. This $\sim 90^{\circ}$ change in least principal horizontal stress orientation along the Rio Grande rift-Great Plains boundary corresponds to a decrease in heat flow and a crustal and lithospheric thickening under the Great Plains in relation to the Rio Grande rift [Thompson and Zoback, 1979]. In addition, seismic reflection profiling across the Rio Grande rift's eastern boundary [Brown et al., 1979] has revealed a high-angle, narrow, linear zone defined by a lack of coherent reflections which extends from near the surface to the base of the crust. Physically, this sharp boundary may mark a zone of lateral 'decoupling' within the crust facilitating the abrupt change in stress orientation. 


\section{STRESS PROVINCES: \\ Central and Eastern United States}

Despite suggestions that the in situ stress field is uniform throughout the eastern United States [e.g., Haimson, 1977b], recent data demonstrate the existence of distinct stress provinces (Plate 2). As in the West, earthquake focal mechanism, geologic, and in situ stress data available for the eastern United States generally yield consistent results. Along the Atlantic coast, the primary data set available is composed of the trends and senses of offset of Tertiary or younger faults. As discussed previously, these data yield only approximate stress directions. A more significant problem concerning these indicators, however, is that chance exposures may reveal secondary features, whereas the primary structure can remain unrecognized. In addition, the general paucity of stress field indicators in the East makes definition of the boundaries between the stress provinces difficult and may tend to give unwarranted significance to isolated data points.

Although the central and eastern United States is generally thought of as a tectonically stable region, numerous historical earthquakes have occurred there (Figure 3). The Charleston,
South Carolina, earthquake of 1886 and the 1811-1812 New Madrid, Missouri, earthquakes dominate the seismic history of the eastern United States, but there are numerous other areas of concentrated seismic activity. Several of the largerscale patterns and trends in eastern seismicity have been summarized in detail by Sykes [1978]. These include the northwest trending seismic zone in South Carolina and Georgia [Bollinger, 1973] and a similarly oriented zone in central Virginia [Bollinger, 1975], the NW-SE trending Boston-Ottawa seismic zone [Diment et al., 1972], the Ramapo fault system in northeastern New Jersey [Aggarwal and Sykes, 1978], the Grand Banks area, the Lower St. Lawrence valley [Leblanc et al., 1973], and a diffuse earthquake trend along the Appalachian fold belt [Woollard, 1969]. Sykes [1978] points out that the Boston-Ottawa seismic zone may not be continuous because of the paucity of activity in southern Vermont and New Hampshire. The boundary separating the Midcontinent and Atlantic Coast stress provinces is shown in Figure 3 by the shaded line. In the southern Appalachians more activity occurs west of the boundary, while in the northern Appalachians the NW-SE trending zone of earthquakes associated with the Ottawa-Bonnechere graben [Sykes, 1978] end

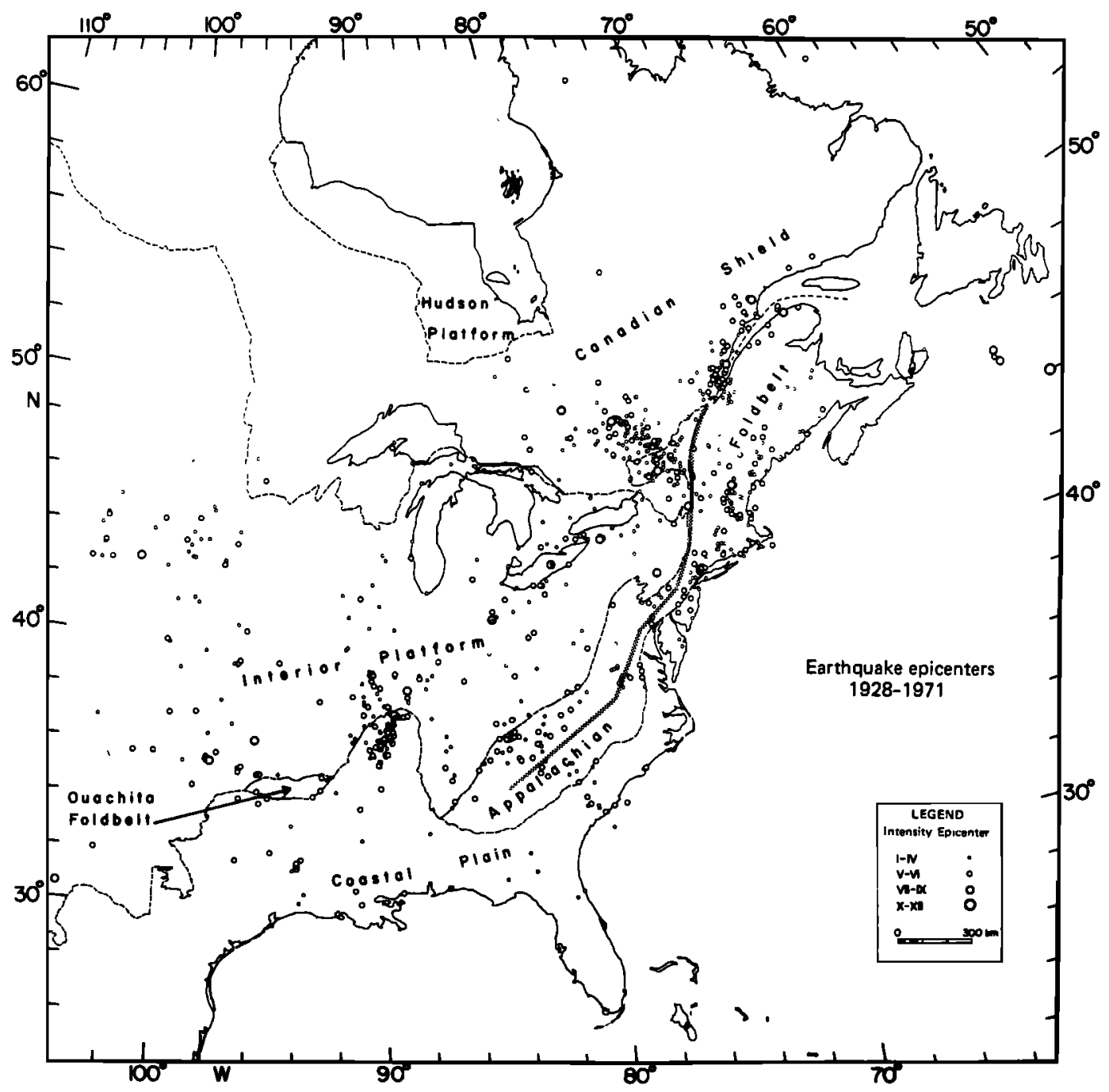

Fig. 3. Seismicity map of eastern North America from historical and instrumental data for the period 1928-1971 from York and Oliver [1976]. Shaded line is stress province boundary between the Midcontinent and Atlantic Coast provinces from Plate 2. 
abruptly at the stress province boundary. Earthquakes extending from New Jersey to New England seem to define a northwestly trend of activity located east of the stress province boundary.

Various sources and mechanisms have been proposed to explain the distribution of intraplate earthquakes in the central and eastern United States. Some of these are preexisting zones of crustal weakness that correlate with zones of alkalic magmatism and major offshore fracture zones [Sykes, 1978], reactivation of a late Precambrian-early Paleozoic continental rift in the New Madrid area [M. D. Zoback et al., 1980a], reactivation of Triassic basin bounding normal faults (with highangle reverse-type motion) along the eastern seaboard [Jacobeen, 1972; Mixon and Newell, 1977; Aggarwal and Sykes, 1978; Behrendt et al., 1980; Wentworth and Mergner-Keefer, 1980; Prowell, 1980], and stress concentrations in the vicinity of igneous intrusions [McKeown, 1978; Kane, 1976].

\section{Midcontinent}

The Midcontinent stress province, a large and tectonically stable region, extends eastward to the Appalachians (and includes the Adirondack uplift), southward to the Gulf Coastal Plain, and westward to the southern Great Plains province. The available data suggest that this stress province can be extended northward into Canada. Throughout this broad province, a uniform NE-SW compressive stress field exists, largely defined by hydraulic-fracturing work of B. C. Haimson [cf. Haimson, 1977b] and earthquake focal mechanisms of R. B. Herrmann [cf. Herrmann, 1979].

The eastern boundary of the Midcontinent stress province is poorly defined but appears to coincide in the south approximately with the eastern edge of the Blue Ridge province, a major topographic break. To the north, where the Appalachian fold belt narrows, the stress province boundary takes a more northerly course crossing the Valley and Ridge province and approximately coincides with the western edge of the Appalachian fold belt. As stress orientations in the Valley and Ridge and Blue Ridge provinces are scattered and locally contradictory (Plates 1 and 2) the eastern $\sim 200 \mathrm{~km}$ of the Midcontinent stress provinces may represent a transition zone between the Midcontinent and Atlantic Coast provinces. The scatter in stress orientations in this region may reflect the inherent uncertainties of the different methods used to determine stress or may represent a broad zone of transition in which the horizontal stresses are approximately equal in magnitude and the apparent stress orientation is more controlled by local inhomogeneties.

Tectonics in the Midcontinent stress province are compressional, and earthquakes throughout the province typically show components of both strike slip and reverse movement. Thus

$$
\begin{gathered}
S_{1} \gg S_{2}>S_{3} \\
S_{\mathrm{NE}} \gg S_{\mathrm{NW}}>S_{\mathrm{v}}
\end{gathered}
$$

The only exception to this pattern was a normal fault earthquake at the edge of the Ozark uplift in southern Missouri (MO-3), but in this case the orientation of the least principal horizontal stress field is consistent with the northwestward direction observed in the remainder of the province (Plates 1 and 2).

Recent seismic reflection profiling in the southern Appalachians [Cook et al., 1979; Harris and Bayer, 1979] have been interpreted as indicating that a major decollement underlies thin-skinned deformation in the miogeosynclinal sequence along the western edge of the belt (Appalachian Plateau and Valley Ridge). This decollement is interpreted to continue eastward beneath Paleozoic and Precambrian rocks previously believed to be rooted forming the mobile core of the Appalachian orogen. Stress orientations within the Appalachian Plateau along the New York-Pennsylvania border (NY$1,2, \mathrm{PA}-3$ ) are parallel to orientations farther to the north and west in the Midcontinent province; these localities lie within detached rock. The orientations at these three sites are also parallel to the stress orientation inferred from the Attica earthquake (NY-3), which is probably deeper than the thrusts now known to have detached the rocks there. Thus the stress data seems to imply that the Appalachian thrust sheet(s) is mechanically coupled to the underlying basement where, presumably, the major earthquakes occur.

The high level of intraplate seismicity in the Northern Missisippi Embayment might appear to warrant delineation of a distinct stress province. Earthquakes within the embayment that occur along a $100 \mathrm{~km}$ long northeast-southwest trending seismic zone in northeast Arkansas (AR-1, 2) indicate predominately strike slip faulting and approximately east-west compression. These earthquakes are occurring on a major basement fault associated with a late Precambrian rift system that is favorably oriented to the regional stress field $[M . D$. Zoback et al., 1980a]. Earthquake focal mechanisms from the roughly north-south trending, relatively diffuse zone of seismicity near New Madrid, Missouri (MO-1, 2), however, indicate thrusting on northwest trending faults and NE-SW compression. This rapid and localized apparent change in stress orientation is observed in both regional surface and body wave studies [Herrmann, 1979] and local studies of microearthquakes [ $O$ 'Connell et al., 1980]. However, the validity of the apparent complex pattern of stress orientations is questionable, as it may be due merely to the uncertainty inherent in inferring stress orientations from focal mechanisms for earthquakes occurring on preexisting faults. Thus as the mean orientation of the stress field in the embayment area is consistent with the surrounding region and the earthquakes are apparently associated with specific itructures, the Northern Mississippi Embayment is included as part, albeit an active part, of the Midcontinent stress province.

\section{Atlantic Coast}

Northwest-southeast to west-northwest-east-southeast compression characterizes the Atlantic Coast stress province, which includes the Atlantic Coastal Plain, the Piedmont province of the southern Appalachians, and the entire Appalachian fold belt in the northeast. In marked contrast to earlier studies suggesting northeast compression for this area [see Sbar and Sykes, 1973], the generally northwest compression is documented by offset core holes (CT-1), hydrofrac measurements (SC-1, MD-2), earthquake focal mechanisms (NJ-1, SC-6, VA-1), and numerous late Cenozoic fault offsets. Because of generally poor, limited exposures and small magnitude vertical offsets the faults are difficult to recognize, and possible lateral offsets of the subhorizontal coastal plain sediments can rarely be established or eliminated. Components of strike slip offset have been postulated for two major reactivated (now reverse) northeast trending fault zones. A component of right-lateral offset has been inferred along the Stafford fault zone (VA-2) from an analysis of subsidiary reverse 
and normal faults within the fault zone [Mixon and Newell, 19771, whereas significant left-lateral offset has been documented in Paleozoic rocks along the Cenozoic Belair fault zone [Prowell and O'Connor, 1978], although this offset can not be recognized in the overlying strata. Lacking data on lateral offsets and given the large uncertainties in stress orientations inferred from only the trend and sense of vertical offset of a fault, the precise horizontal principal stress orientation remains poorly defined. However, the excellent correspondence between stress orientations inferred from the trend of reverse faulting along the Stafford (VA-2) and Brandywine (MD-1) and a nearby in situ stress measurement (MD-2) imply that the predominant sense of modern motion on these fault zones is reverse. Further substantiation of the Atlantic Coast stress province and its continuation into New England is provided by a recent compilation of 18 focal mechanisms in the area east of $73^{\circ} \mathrm{W}$ longitude and north of $43^{\circ} \mathrm{N}$ latitude that indicate largely reverse faulting on $\mathrm{N}$ to NE striking planes implying E-W to NW-SE compression ([Graham and Chiburis, 1980] these data have not been included in this study because of the late date at which they became available).

Earthquakes in the Atlantic Coast province often have components of both thrust and strike slip motion [cf. Aggarwal and Sykes, 1978; Graham and Chiburis, 1980]. Such oblique motion is expected because the earthquakes seem to occur on favorably oriented preexisting structures. For modern earthquakes associated with northeast striking normal faults which bound Triassic basins the current sense of motion (reverse) on the fault is exactly opposite to the motion that created the faults. For the Atlantic Coast stress province therefore

$$
\begin{gathered}
S_{1}>S_{2}>S_{3} \\
S_{\mathrm{NW}}>S_{\mathrm{NE}}>S_{\mathrm{v}}
\end{gathered}
$$

An early earthquake focal mechanism study near Charleston, South Carolina, suggested dip slip motion on a near-vertical, northwest striking fault plane [Tarr, 1977]. For that event the $P$ and $T$ axes both strike in the northeast-southeast direction and plunge $\sim 45^{\circ}$. Because the horizontal components of both the $P$ and $T$ axes have the same azimuth (and the relative magnitude of the stress component in the null direction is unknown), the direction of least horizontal compression could not be determined. More recent focal mechanism data indicate reverse motion on both NE and NW trending faults and thus suggest that the horizontal stresses may be approximately equal (A. Tarr, written communication, 1980). Northeast trending high-angle reverse faults with Tertiary offset, recently discovered by seismic reflection profiling near Charleston by Behrendt et al. [1980] are indicative of NW-SE compression.

\section{Gulf Coast}

Active listric growth faulting characterizes the Gulf Coast stress province. The stress directions used to define this province were taken from the average local orientation of recently active faults at each site, from the fault map by Howard $e t$ al. [1978], and from recognized late Tertiary normal faulting. The axis of most currently active faulting runs near and seaward of the present shoreline. The northern boundary of this province is constrained only by a strike slip earthquake in Mississippi (MS-3). The state of stress throughout this province is apparently quite uniform: the greatest principal stress is vertical, the orientation of the least principal stress is perpendicular to the continental margin, and the magnitude of the least principal stress is $60 \%$ of the vertical stress [cf. Hubbert and Willis, 1957; M. D. Zoback et al., 1978]. It should be emphasized that the state of stress in this province is probably only the result of sediment loading and not tectonic forces. The state of stress within the bedrock underlying Gulf Coast sediments remains unknown.

\section{SOURCES OF STRESS}

In this section we investigate some of the major sources of lithospheric stress in terms of the patterns and relative magnitudes of the stresses that characterize the provinces defined above. The state of stress in the earth's lithosphere is the result of superposition of forces derived from many different processes. It is often possible, however, to identify the predominant force or forces responsible for the pattern of stress field within a given region. The broad patterns of stress are best explained by plate tectonic forces (see Richardson et al. [1979] for a comprehensive review both tectonic and nontectonic sources of stress).

\section{Sources of Stress in the Western United States}

The most important source of stress affecting the western United States is current and past plate motions along the western plate boundary. The pattern of stress in many of the stress provinces in this region can be attributed directly either to present transform motion between the Pacific and North America plates or residual thermal and dynamic effects of past subduction. The northwesterly motion of the Pacific plate with respect to North America results in right-lateral transform motion along the northwest trending San Andreas and Fairweather fault systems, N-S crustal shorterning in the Transverse Ranges of Southern California, and distributed right-lateral deformation superimposed on the extension occurring in the Basin and Range province. The Sierra Nevada, characterized by both normal and strike slip faulting, appears to represent a transition zone between the San Andreas and Basin and Range stress provinces.

North-south compression characterizes the Pacific Northwest stress province, a region including an active andesitic volcanic chain and the back arc area. This direction of compression is roughly parallel to the trend of the offshore trench, and it is about $45^{\circ}$ oblique to the northeast-southwest direction of convergence between the Juan de Fuca and North American plates. Whereas in other back arc areas under compression the maximum compressive stress orientation is in the direction of plate convergence [Nakamura et al., 1978], this is not the case in the Pacific Northwest province. Crosson [1972] has suggested that decoupling between the subducting Juan de Fuca plate and the overriding North American plate may be consistent with estimates of a relatively slow rate of convergence and the absence of an inclined seismic Benioff zone beneath western Washington and Oregon. If this decoupling has occurred, then the stress field may be controlled more by the larger-scale transform motion between the Pacific and North American plates. An observation in possible support of this concept is the rather limited extent of the Juan de Fuca plate (extending from approximately $40^{\circ} \mathrm{N}$ to $51^{\circ} \mathrm{N}$ ) in relationship to the extensive San Andreas and Fairweather rightlateral transform fault systems which form most of the remainder of western plate boundary of North America. Another hypothesis to explain the N-S crustal shortening in the 
Pacific Northwest province was proposed by $R$. B. Smith [1977]. Within the context of a subplate model of the entire western Cordillera he suggested that the N-S shortening in the Pacific Northwest may be due to compression between a N-S extending Northern Rocky Mountain subplate (with a NW trending western boundary) and the Juan de Fuca plate. The available stress data, however, though admittedly sparse, suggest generally east-west extension in the Northern Rocky Mountain province with only a small area of north-south extension in the Hebgen Lake-Centennial Valley stress province (discussed below).

The origin of present-day extensional tectonism in the Basin and Range and Rio Grande rift provinces has been the subject of numberous investigations (see Stewart [1978] for a summary of the various proposed theories). Models for the origin of the modern state of stress must take into account the late Cenozoic evolution of the western plate boundary. Subduction under the western United States in middle Tertiary time destroyed the subducting Farallon plate more rapidly than it was being created, resulting in a ridge-trench encounter and development of the San Andreas transform accommodating the relative motion between the Pacific and North American plates [Atwater, 1970; Atwater and Molnar, 1973]. Initial ridge-trench encounters occurred between 20-30 m.y. B.P., possibly $\simeq 29$ m.y. B.P., and probably closely coincided with the initiation of right-lateral transform faulting. Since its inception, the right-lateral transform boundary has continued to lengthen at the expense of the subduction zone.

Extensional tectonism in the Basin and Range and Rio Grande rift was initiated in both an intra-arc and back arc setting [e.g., Eaton, 1979; Elston and Bornhorst, 1979]; true basinrange structure, the fault-controlled sedimentary basins and topographic forms resembling those seen today, can be considered a unique late-stage episode of extensional tectonism [M. L. Zoback et al., 1980]. The general NNE trend of ranges in the northern Basin and Range, roughly perpendicular to the modern least principal stress direction, suggests development of this region in a stress field similar to the modern one. This NNE trend of faulting contrasts markedly with the general NW trend of the structural grain in the southern Basin and Range. The Rio Grande rift and the individual ranges within it trend roughly N-S and are thought by some to follow a zone of weakness resulting from superimposed earlier deformations [e.g., Chapin and Seager, 1975].

A low level of modern seismicity as well as geomorphic evidence (including the paucity of Quaternary scarps) argue that much of the deformation responsible for present-day ranges and basins in the southern Basin and Range occurred earlier than that in the northern Basin and Range. The general NW trend of the structural grain in the southern Basin and Range suggests that the region developed largely under a stress field oriented differently from the modern one [Eaton, 1979]. Dike trends and extension directions inferred from fault trends and related stratal tilt directions suggest a SW-NE to WSW-ENE direction throughout the western United States in Miocene time ( 20-10 m.y. B.P.) [M. L. Zoback and G. A. Thompson, 1978; M. L. Zoback et al., 1980]. This least principal stress direction is roughly perpendicular to the trend of the ranges in the southern Basin and Range and is oriented $\sim 45^{\circ}$ different from the modern WSW-ENE least principal stress direction. Regional studies in the southern Basin and Range indicate that major basin-range faulting, responsible for the modern ranges, occurred 13-10 m.y. B.P. and probably continued up until about 6 m.y. B.P. [Eberly and Stanley, 1978; Scarborough and Shaffiqullah, 1979]; whereas in the northern Basin and Range, basin-range faulting was initiated post 10 m.y. B.P. and in places post-7 m.y. B.P. under a stress field oriented similarily to the modern one (M. L. Zoback et al., 1980]. The $\sim 45^{\circ}$ clockwise change in stress orientation occurred between 14-7 m.y. B.P. (possibly around $10 \mathrm{~m} . y$. B.P.) as constrained both locally and by regional differences in faulting trends [ $M$. L. Zoback et al., 1980].

M. L. Zoback and G. A. Thompson [1978] attributed the clockwise change in stress orientation to superposition of dextral shear related to the development of the San Andreas transform on the Miocene back arc extensional stress field. Since transform faulting may have begun as early as $29 \mathrm{~m}$.y. B.P., the change in stress orientations may mark the timing of significant or increased coupling of right-lateral shear between the Pacific and North American plates. This increased coupling may have resulted from one or a combination of the following effects: (1) lengthening of the San Andreas transform to a 'critical' length [see Christiansen and McKee, 1978], (2) an acceleration of relative motion between the Pacific and North American plates at approximately 10 m.y. B.P. [Atwater and Molnar, 1973], and (3) greater normal stress and hence increased friction, along the San Andreas possibly due to small change in the pole of rotation.

Distributed right-lateral shear related to the San Andreas transform, superimposed on fundamental extension within the Basin and Range has been proposed to explain the modern state of stress in the Basin and Range [e.g., R. B. Smith, 1977, 1978; Eaton et al., 1978, Stewart, 1978; M. L. Zoback and G. A. Thompson, 1978; Eaton, 1979, 1980]. Continued extensional tectonism in a 'back transform' setting may be related to development of a gradually enlarging 'slab-free' region beneath the part of the continental block adjacent to the San Andreas transform, while subduction continues to the north and south of the transform [Dickinson and Snyder, 1979]. Dickinson and Snyder attribute basin-range extensional tectonism and bimodal volcanism to upwelling of hot asthenosphere replacing the volume of mantle formerly occupied by the subducted slab of lithosphere [cf. Stewart, 1978; Best and Hamblin, 1978].

Second-order effects can be invoked to explain regional variations of the stress field within the Basin and Range stress province. The regional variation from WNW to NW extension on normal, oblique slip, and strike slip faults in the western Great Basin (northern Basin and Range) to $\sim \mathrm{E}-\mathrm{W}$ directed, pure extension in the Great Basin has been attributed to an eastwart diminishing effect of distributed shear related to the transform plate boundary on basin-range extension [ $R$. B. Smith, 1977, 1978; Best and Hamblin, 1978; Eaton et al., 1978; Eaton, 1979; Davis, 1979]. The apparent WNW extension documented by the present study in the Rio Grande rift, which lies still farther east, remains unexplained by this hypothesis.

A second major regional variation in least principal stress orientation within the Basin and Range (and possibly the Sierra Nevada) occurs in a broad east-west trending band transecting southern Nevada and Utah. In this region the least principal stress directions trend more northwestward and represent a clockwise rotation relative to the well-established WNW-ESE to E-W extension in the region to the north. This east-west trending band that crosses the southern Great Basin coincides with an east-west trending zone of seismicity and a major decrease in elevation from the Great Basin (mean ele- 
vation, $\sim 1700 \mathrm{~m}$ ) to the Arizona-New Mexico (southern) Basin and Range (mean elevation, $\sim 750 \mathrm{~m}$ ) that is accompanied by a $\sim 100 \mathrm{mGal}$ increase in gravity of crustal origin [Eaton et al., 1978]. Presumably, this east-west trending zone acts as the boundary between the actively extending region to the north and the currently tectonically quiescent southern Basin and Range. Thus this zone can be interpreted as a broadband of left-lateral transform-style shearing consistent with focal mechanisms and geologic evidence [Stewart, 1978] in that region. Locally, this left-lateral shearing (or drag resistance to this shearing) could cause a clockwise rotation of the stress field, compatible with the more northwestward least principal stress orientations observed in that region.

The E-W to NE-SW extension in the Northern Rocky Mountain province may represent a northward continuation of basin-range extension across the Snake River plain. Modern least principal horizontal stress orientations for the Snake River plain are NW-SE, parallel to the axis of the plain, not perpendicular to it. Profound migrating volcanism along the Snake River plain has been attributed to a mantle hot spot [Morgan, 1972; Suppe et al., 1975] and to a propagating lithospheric crack possibly alined with a preexisting zone of weakness [e.g., $R$. B. Smith et al., 1974b; Eaton et al., 1975]. In favor of the hot spot model an inversion of relative plate motions to a mantle reference frame indicate that the absolute motion of the North American plate for the last $\mathbf{1 0}$ m.y. is well represented by the Snake River plain-Yellowstone trend [Minster and Jordan, 1978].

The N-S extension in the Hebgen-Lake-Centennial Valley province appears to represent a local anomaly in the regional pattern of E-W or NE-SW extension in the Snake River plain to the south and the Northern Rocky Mountains to the north. R. B. Smith and M. L. Sbar [1974] first recognized this local deviation in the stress field and suggested that it resulted from a generally N-S relative separation of the Northern Rocky Mountains and the Great Basin in their subplate scheme for the western United States. The abrupt southern boundary of this province in the Yellowstone area, however, suggests that the N-S extension may be a local, possibly second-order effect related to the actual mechanism or cause for the profound propagating volcanic trend along the eastern Snake River plain.

The Colorado Plateau interior appears characterized by WNW-ESE compression, i.e., compression in the direction of extension in the surrounding Basin and Range and Rio Grande rift provinces. The source of this WNW directed compression within the plateau interior remains equivocal. Asthenospheric 'drag' (discussed below) can be ruled out, as the direction of absolute velocity of the plateau is SW, nearly perpendicular to the WNW direction of maximum horizontal compression. Thompson and Zoback [1979] have suggested that the overall state of compression in the Colorado Plateau interior may be related to its thick 'keel' of mantle lithosphere, the edges of which are subjected to a static 'ridge push' force (also discussed below) resulting from density contrasts by surrounding, less dense asthenosphere under the Basin and Range-Rio Grande rift. However, shallow (crustal level) density contrasts between the plateau and surrounding regions predict extensional stress differences in the upper crust along the margins of the plateau.

The parallelism between the direction of greatest principal stress on the plateau and the direction of regional extension in the surrounding Basin and Range-Rio Grande rift province suggests that the source of the compression within the plateau interior may be related to dynamic (drag?) forces resulting from the regional extension. The stress differences arising from lateral density contrasts along the plateau margins may represent a second-order effect superimposed on a more regional stress field. $R$. B. Smith [1977] proposed that the roughly E-W compression within the Colorado Plateau is due to the buttress effect between the western deforming Cordillera and the eastern stable interior. Such an interpretation is valid only if a fixed boundary exists for the western deforming zone; if, however, this boundary is considered free, then extension in both the Rio Grande rift and Basin and the Range need not necessarily affect the plateau stress field.

A probably extensional stress regime in the southern Great Plains distinguishes that province from the Colorado Plateau interior (which appears to be dominated by compressional tectonism) despite similar least principal stress directions in the two regions. The source of the apparent NNE-SSW extension in the Southern Great Plains is obscure and is in marked contrast to the roughly E-W compression responsible for development of the Rocky Mountains in Laramide time ( $~ 80$ 40 m.y. B.P.). Furthermore, analysis of the 22-25 m.y. Spanish Peak radial dike system in south-central Colorado $\left(37.63^{\circ} \mathrm{N}\right.$, $104.88^{\circ} \mathrm{W}$ ) suggests a strike slip regime with a $\mathrm{N} 8^{\circ} \mathrm{W}$ least principal horizontal stress orientation [Muller and Pollard, 1977]; this orientation is $20^{\circ}-40^{\circ}$ oblique to inferred least principal horizontal stress directions for past $5 \mathrm{~m}$.y. cindercone alinements in the Raton-Clayton volcanic field directly to the south in New Mexico.

\section{Sources of Stress in the Central and Eastern United States}

To account for the stress field in this broad midplate region, we consider two large scale sources of stress; 'asthenospheric drag' and ridge push. Asthenospheric drag is viscous resistance to motion of the thick continental lithosphere. Most simply, if the asthenosphere beneath the continents is stationary, a basal shear stress is induced by the motion of the continental lithosphere in the direction opposite to the direction of absolute plate motion [Richardson et al., 1976]. A somewhat related source of stress is asthenospheric counterflow; numerous theoretical models have been developed in which the asthenosphere beneath the continents flows in directions determined by the total mass flux: that which is produced at ridges and consumed at subduction zones [Harper, 1978; Chase, 1979; Hager and O'Connell, 1979]. In this case the asthenosphere has a direction of motion not necessarily related to the absolute plate motion direction, and the resulting stress in the lithosphere should be in the direction of asthenospheric flow. The absolute and counterflow velocity directions are nearly parallel for the Pacific plate, which, because of its size and speed, is the prime determinant of the large-scale flow pattern; however, for other plates the directions can differ up to $90^{\circ}$.

Broad-scale lateral density inhomogenities give rise to lithospheric stresses such as the ridge push force [e.g. Frank, 1972; Artyushkov, 1973]. These forces arise because lateral changes in the thickness of the crust and lithosphere (and changes in crustal density) result in buoyance forces oriented normal to the interface defining the lateral density change. As only the vertical component of this bouyance force is compensated isostatically, a net horizontal force is left. For example, ridge push results from both the elevation of the midocean ridge and the cooling and thickening of the lithosphere away from 
the ridge; the magnitude of the stress derived from is ridge push force is estimated at several hundred bars [Hales, 1969; Frank, 1972; McKenzie, 1972; Artyushkov, 1973]. Other examples of lateral density inhomogeneities include lateral variations in crustal densities and thickness (e.g. ocean-continental crust interface [Bott and Dean, 1972]) as well as lateral contrasts in lithosphere thickness.

To examine sources of stress in the central and eastern United States, Figure 4 compares the direction of maximum horizontal compression with computed directions of (1) absolute motion of the North American plate and (2) ridge push (from the relative motion of North America and Europe), using poles of rotation from Minster and Jordan [1978]. (The orientation of the fundamentally E-W compression derived from ridge push would have been modified only slightly if the pole of relative motion between North America and Africa had been used.) As can be seen, the relative and absolute velocity azimuths differ by only $\sim 10^{\circ}$ throughout the central and east- ern United States. The asthenosphere counterflow models mentioued previously result in basal shear stress directions (lithospheric compressive stress directions) indicated by the large arrows in Figure 4 [after Chase, 1979].

As can be seen in Figure 4, the roughly NE-SW compression in the Midcontinent stress province is generally consistent with either ridge push or asthenospheric viscous drag resistance to absolute plate motion. Examination of the histogram inset in Figure 4, however, indicates that drag resistance directions correlate better with the stress data than do the ridge push directions, suggesting that drag may be the primary source of stress in the Midcontinent province.

A potential problem with the asthenospheric drag hypothesis is that the magnitude of the basal stress (based on plate velocity and asthenospheric viscosity) is typically interpreted to be quite low [e.g., Chapple and Tullis, 1977; Richardson et al., 1976; Chase, 1979]. However, the cold thick lithosphere beneath the Midcontinent region and the lack, or poor develop-

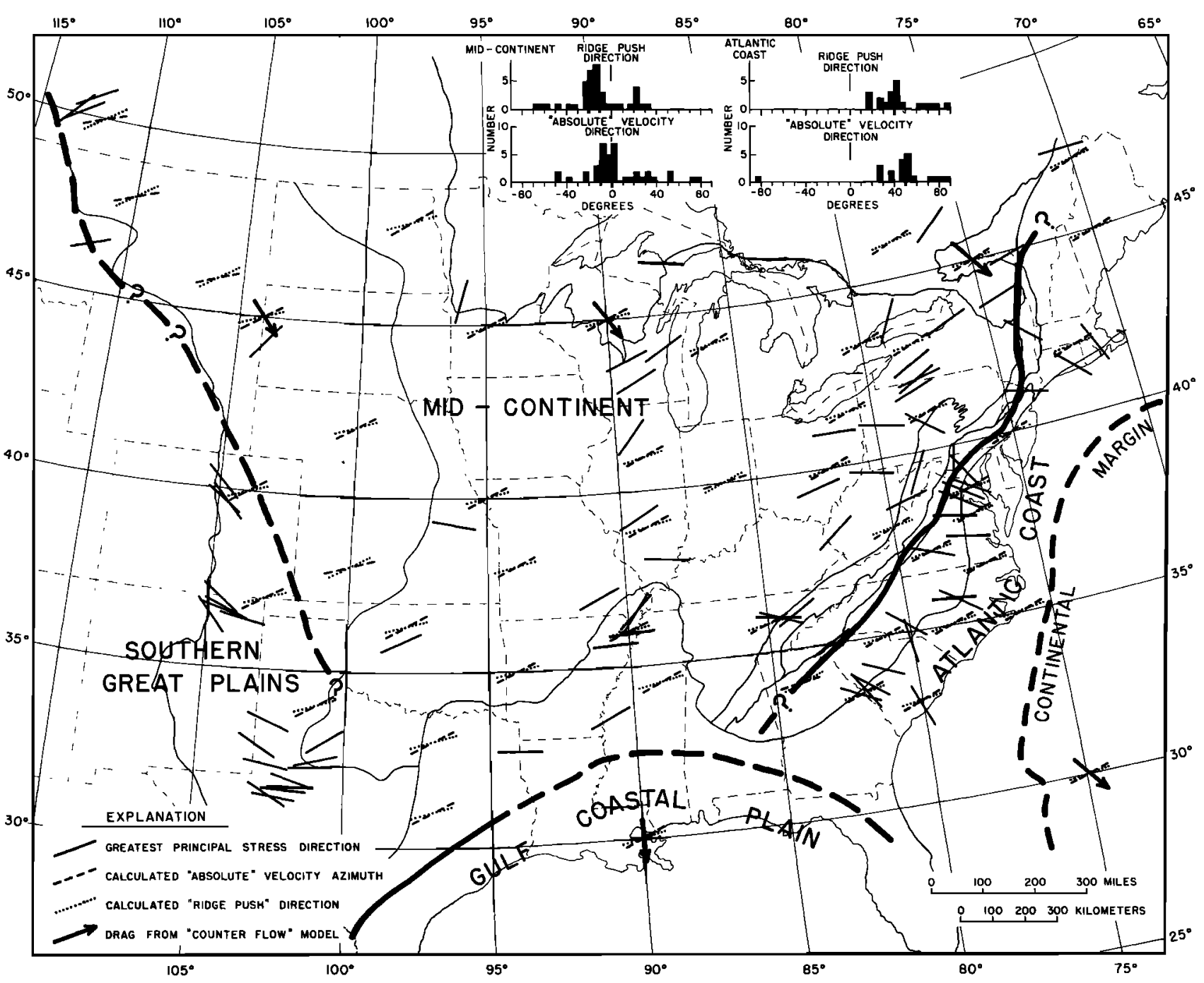

Fig. 4. Comparison of greatest horizontal principal stress directions (from Plate 2) with predicted maximum compressive stress directions derived from ridge push (dotted lines) and drag resistance to 'absolute' plate velocity (dashed lines) calculated from poles of rotation of Minster and Jordan [1978] (see text). Large arrows show direction of net asthenospheric counterflow from models of Chase [1979]; drag-induced compressive stress in the lithosphere would have the same orientation as the flow. Heavy solid lines mark stress province boundaries, as in Plate 2. Short dashed lines mark edge of the continental margin. Inset histograms show angular deviation of stress data from predicted ridge push and absolute velocity directions. Positive deviation (to the right) indicates a clockwise orientation of the actual data in relation to the calculated direction, negative deviation indicates a counterclockwise orientation of the data in relation to the calculated direction. 
ment, of a low-velocity zone [Herrin, 1972; Chapman and Pollock, 1977] imply that the base of the lithosphere may extend into more viscous mantle material. This implies that the resistance to lithospheric motion may be fairly large. If estimates of flow stresses based on grain size analysis of xenoliths are correct, the magnitude of shear stresses in the lower lithosphere could exceed 100 bars [Mercier, 1980].

Compressive stress directions predicted from asthenospheric counterflow models discussed previously (large arrows Figure 4) are nearly $90^{\circ}$ different than observed maximum compressive stress directions in the Midcontinent region. This large discrepancy implies that as modeled, asthenospheric counterflow is not an important process controlling the intraplate stress field. Perhaps asthenospheric flow gets channeled around regions of thick continental lithosphere, and current models assuming a uniform lithosphere thickness worldwide are too simplistic. It is also possible that the flow occurs at such great depths as to not affect the lithospheric stress field.

In the Atlantic Coast province, maximum compression appears to be oriented NW-SE, perpendicular to the trend of the Appalachian fold belt and the continental margin. As can be seen Figure 4 and the inset histogram, both ridge push and drag resistance to absolute velocity are in poor agreement with the observed maximum horizontal compression in the Atlantic Coast province, whereas compressive stresses predicted from the asthenospheric counterflow model match the observed orientations quite well. However, as this counterflow is directed from the northwest, it appears unlikely that it could exert a significant effect on the lithospheric stress field in the Atlantic Coast province without having any apparent influence on the stress field in the Midcontinent region.

The fact that the orientation of the maximum compressive stress in the Atlantic Coast province is roughly perpendicular to the trend of the Appalachian fold belt and the continental margin would seem to suggest some sort of causal relationship. However, lateral density contrasts associated with crustal structure at a passive continental margin predicts extension perpenticular to the continental margin rather than the observed compression [e.g., Bott and Dean, 1972]. Lithospheric flexture resulting from sediment load also predicts extension on the continental margin [Walcott, 1972; Watts and Ryan, 1976; Turcotte et al., 1977]. Compressive stresses derived from major lithospheric thickening along the edge of the continent also appear unlikely; available data suggest little or no contrast in thickness between continental and oceanic lithosphere in this region. While no seismic investigations are available for the Atlantic Coastal Plain or the Appalachian region, surface wave studies of the Gulf Coastal Plain indicate a possible lithosphere thickness between 80 and $145 \mathrm{~km}$ [Biswas and Knopoff, 1974]. Age of the oldest oceanic lithosphere in the central Atlantic is generally believed to be 180-190 m.y. [Watts and Ryan, 1976]. Surface wave studies in the western Pacific suggest a thickness of $140 \pm 35 \mathrm{~km}$ for oceanic lithosphere with a mean age of 150 m.y. [Leeds et al., 1975].

As mentioned previously, seismic reflection profiling in the southern Appalachians have been interpreted as indicating a major decollement (detachment) beneath the Appalachians extending eastward from the leading (western) edge of the fold and thrust belt to beneath the Piedmont [Cook et al., 1979; Harris and Bayer, 1979]. Southeastward directed gravitational backsliding along this detachment (and its postulated eastward extension beneath the Coastal Plain) has been suggested as a mechanism to explain the observed orientation of compressional stress along the Atlantic Coast province [Seeber and Armbruster, 1980]. Such a mechanism predicts extensional stresses in the main elevated core of the Appalachians. However, the only available stress data in that region [Schäfer, 1979] indicates Recent thrusting, implying a compressional state of stress.

Slowly accumulating flextural stresses in response to erosion-induced isostatic rebound of the Appalachians is a somewhat speculative mechanism that would generate compressive stress perpendicular to the topographic trend of the Appalachians. An analogy to this process is unloading due to melting of an ice sheet [see Stein et al., 1979]. Unloading results in extensional flextural stresses in the area where the load is removed (Appalachians) and compressional stresses in the adjacent area (coastal plain). Thus in a general sense, erosion in the Appalachians may induce the type of compressional stress field observed in the central and southern Atlantic Coast province. A reasonable average erosion rate for the Appalachians is about $3 \times 10^{-2} \mathrm{~mm} / \mathrm{yr}$ [Hack, 1979], and throughout the Cenozoic, isostatic rebound has apparently kept the mean elevation of the mountains nearly constant [Hack, 1979]. Flexure produced by isostatic rebound will result in an accumulation of about 100-150 bars of compressional stress in the upper $10 \mathrm{~km}$ of the lithosphere every $10 \mathrm{~m} . \mathrm{y}$. [see Stein et al., 1979]. This does not seem to be an unreasonable rate of stress accumulation in light of the low recurrence rate inferred for great earthquakes in the Atlantic Coast province on the basis of the small magnitude of post $100 \mathrm{~m}$.y. cumulative fault offsets (D. C. Prowell, written communication, 1980). Difficulties with the erosion-induced flexture hypothesis are (1) predicted extensional deformation within the rebounding Appalachians is not observed and (2) the correlation between topography and the predicted areas of compressive stress in New England is not good. However, the effects of glacial loading in the New England area may complicate the stress field in that region.

A second speculative mechanism that might result in the maximum compressive stress direction being perpendicular to the Appalachian fold belt is a reorientation of the stress field by highly anisotropic basement structure (N. H. Sleep, oral communication, 1980). In other words, a compressive stress field resulting from ridge push or asthenospheric drag might be oblique to the fold belt (Figure 4), but the direction of maximum compression is rotated by the anisotropic structure perpendicular to the compliant direction.

It may seem fruitless to try to identify a single, or dominant, source of stress field in the Atlantic Coast province. The stress field may reflect superpositon of erosion and sedimentation induced flexture, deglaciation, ridge push, asthenospheric drag, and other sources. However, available data on faulting in the Atlantic Coastal Plain (D. C. Prowell, written communication, 1980) indicate that directions, senses, and rates of motion on faults in this region have not changed markedly in the last $110 \mathrm{~m} . y$. , thus suggesting that a similar stress field has acted throughout that entire time period.

In the Gulf Coastal Plain the seaward extension caused by active normal faulting appears consistent with the state of crustal stress at a passive continental margin predicted by lateral density variations such as those described by Bott and Dean [1972]. However, as the active faults are listric growth faults within the sedimentary section, it is possible that the faulting merely reflects the effect of sediment loading and not the state of lithospheric stress. Since the source of stress in the 
Atlantic Coast province remains poorly understood, the state of stress within the Gulf Coast basement might be dominated by a stress field similar to that in the Atlantic Coast province, the Midcontinent province, or it may be dominated by lithospheric flexural effects resulting from the sedimentary load.

\section{Discussion}

\section{Stress Field Indicators}

The regional consistency of the in situ stress data presented above implies that they generally reflect the pattern of stress in the crust. At a given locality the good correspondence of the various methods used to determine stress orientations suggests that the assumptions required to determine principal stress orientations by the different methods are basically valid. At the Nevada Test Site (NV-3), for example, all three methods were utilized: hydraulic fracturing and overcoring at depth, geologic indicators, and strike slip and normal faulting (as well as oblique slip) earthquake focal mechanisms yield consistent results. Furthermore, the generally good correspondence of stress orientations inferred from focal mechanisms which commonly sample the depth range $5-15 \mathrm{~km}$ and from geologic and in situ stress indicators which generally sample the upper $\sim 2 \mathrm{~km}$ implies a relatively uniform stress field throughout the upper crust $(<15 \mathrm{~km})$. This observation lends confidence to extrapolation of the near-surface stress field $(\leq 2$ $\mathrm{km}$ ) to depths comparable to those of major earthquakes and also suggests that in situ stress measurements can be used to fill important gaps in the current data set.

The least reliable regional tectonic stress indicator seems to be the overcoring measurements made in mines. For example, in the Coeur d'Alene district in Idaho (ID-7), markedly different stress orientations and magnitudes were obtained from two measurements in mines $<3 \mathrm{~km}$ apart at nearly the same depth. It is unclear whether these methods are, at times, unreliable because of perturbations in the stress field due to mining operations or because the mines are typically in areas of complex geologic structure and history.

Hydraulic fracturing seems to be a reliable stress measurement technique when done at depths sufficient to avoid the effects of topography [Haimson, 1979] and near-surface fracturing [M. D. Zoback et al., 1980b]. Care must also be taken with this technique to insure that a preexisting fracture or joint was not opened rather than a hydraulic fracture at the well bore. The consistent 11 sets of hydrofrac measurements in western Texas [Zemanek et al., 1970] demonstrate the usefulness of the hydrofrac technique to define regional stresses.

Despite the fairly large uncertainties inherent in using focal plane mechanisms for determining stress orientations, a generally good agreement exists between orientations determined from focal mechanisms and other techniques. Focal mechanism data are probably most reliable where earthquakes occur on fault planes of varying trend in a given area, so that the average of $P$ or $T$ directions can be used [cf. M. L. Zoback and $M$. D. Zoback, 1980]. Where small earthquakes occur in areas of sparse network coverage, large errors are possible. Whenever possible, the use of surface waves to constrain focal mechanisms seems to be advantageous; an earthquake in the Attica, New York area (NY-3) is a good example. The stress direction resulting from the surface wave mechanism of Herrmann [1979] is more consistent with nearby stress measurements than that constrained by body waves alone [Fletcher and Sykes, 1977].
The geologic stress indicators considered here also involve difficulties. Dike trends and cinder cone alinements are not always linear and can be influenced by favorably oriented preexisting fracture and joint sets. To use fault slip data correctly, major block movement should be considered because anomalous small-scale movements may occur between major blocks and thus yield erroneous results. The use of offset-core hole data, such as those of Schäfer [1979], can be questioned because the magnitudes and rates of movement are so large (centimeters of motion in several years) as to be possibly nontectonic in origin.

\section{Stress Provinces}

On the basis of the orientations and relative magnitudes of principal stresses (determined from the current style of tectonism) we have divided the United States into stress provinces. Figure 5 shows a generalized version of the stress map on which the stress provinces are indicated; a summary of the principal stress orientations and current styles of tectonism for the different stress provinces is given in Table 2 . It is quite likely that these stress provinces, particularly in the East, will be refined as new data accumulate. The present boundaries appear to represent the most general interpretation of the stress data consistent with available information. Although more complex patterns could be drawn, present data coverage does not appear to warrant them.

In general, in the tectonically active western United States the stress pattern is complex, and numerous distinct stress provinces can be well delineated. These stress provinces generally correlate well with the physiographic provinces. In the central and eastern United States, it is apparent even from the relatively sparse data coverage that the state of intraplate stress is not uniform despite the relative tectonic quiescence of that region. The available data appear to define several major areas of consistent principal stress orientation.

Within the stress provinces defined in this study the orientation of the least principal horizontal stress field is generally uniform (to $\pm \sim 15^{\circ}$, within the estimated accuracy of the different methods used to determine stress orientations). In the Midcontinent stress province, the orientation and possibly also the relative magnitude of the principal stresses appear uniform over a broad region with linear dimensions up to $2000 \mathrm{~km}$. The smallest areas characterized by a distinct stress field are in the western United States. Both the Rio Grande Rift and the Hebgen Lake-Centennial Valley stress provinces are $\simeq 150-200 \mathrm{~km}$ wide and exhibit differently oriented stress fields and different styles of tectonism relative to surrounding areas.

In addition, broad areas up to $1000 \mathrm{~km}$ wide that cross stress province boundaries are characterized by a relatively uniform least principal stress direction. In those areas the different stress provinces are distinguished on the basis of the relative magnitudes of the principal stresses and the styles of deformation. The most obvious example of this distinction is in the western United States, where the least principal stress direction in the San Andreas, Sierra Nevada, and Basin and Range-Rio Grande rift provinces is fairly uniformly westnorthwest. If this distinction is broadened to include areas with similarly oriented principal stress axes (NNE, WNW, and vertical) but with different relative magnitudes of horizontal stresses, then both the Colorado Plateau interior and the southern Great Plains can also be included. Principal 


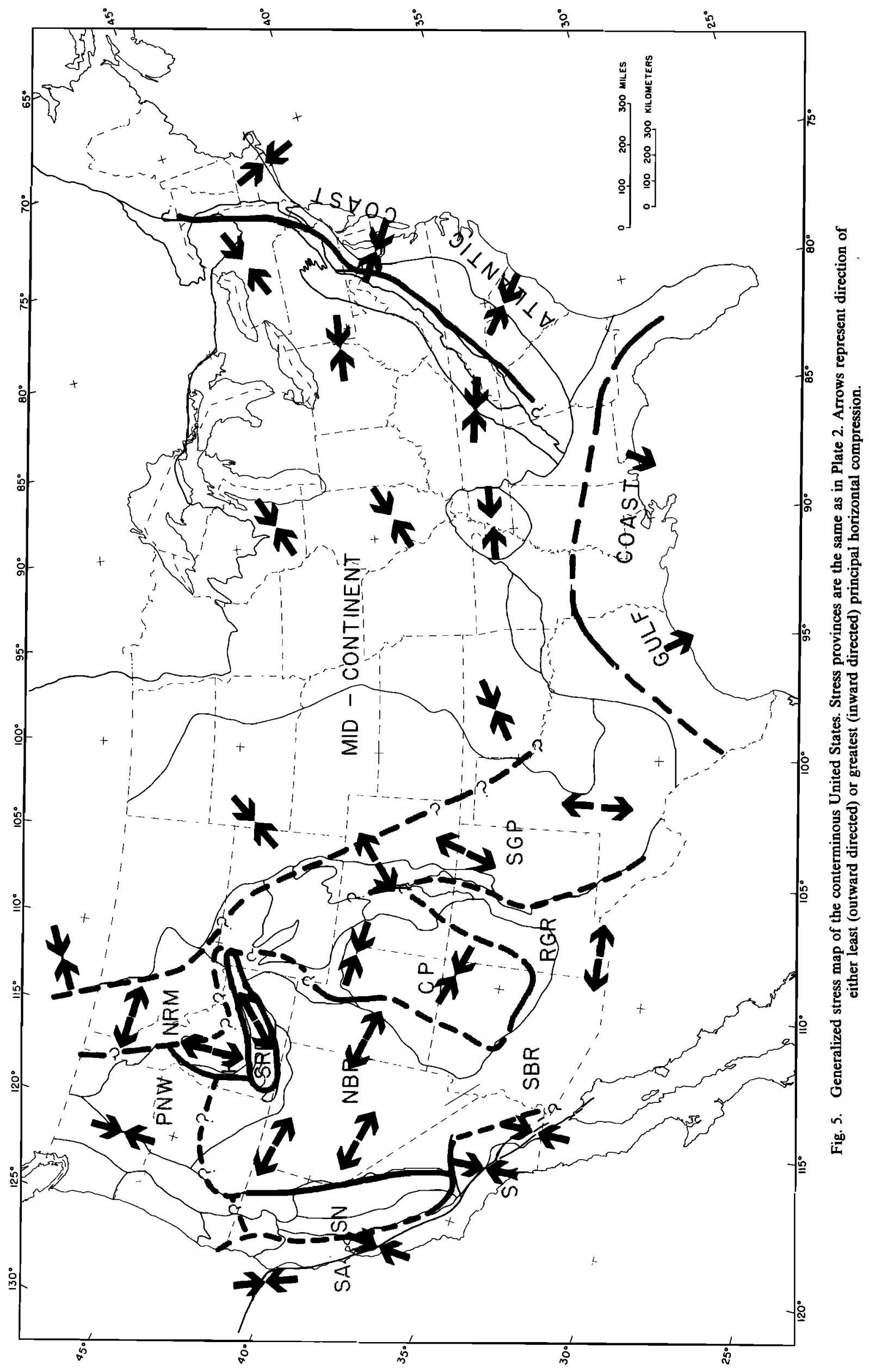


TABLE 2. Summary of Stress Provinces

\begin{tabular}{|c|c|c|c|}
\hline Stress Province & $\begin{array}{l}\text { Primary } \\
\text { Mode(s) of } \\
\text { Faulting } \\
\text { (Secondary } \\
\text { Mode)* }\end{array}$ & $\begin{array}{l}\text { Least } \\
\text { Principal } \\
\text { Horizontal } \\
\text { Stress } \\
\text { Direction }\end{array}$ & Comments \\
\hline Pacific Northwest & $\mathbf{T}+\mathbf{S S}$ & E-W & $\begin{array}{l}\text { both thrust and strike slip focal mech- } \\
\text { anisms; late Tertiary to Quaternary } \\
\text { folding along E-axes in eastern part } \\
\text { of province }\end{array}$ \\
\hline San Andreas & SS (T) & $\mathrm{E}-\mathrm{W}$ to $\mathrm{WNW}$ & $\begin{array}{l}\text { predominantly strike slip deformation } \\
\text { except in Big Bend region, where a } \\
\text { large component of thrust and reverse } \\
\text { faulting exist; local normal faulting } \\
\text { between right-stepping en echelon off- } \\
\text { sets of fault }\end{array}$ \\
\hline Sierra Nevada & $\mathbf{N}+\mathbf{S S}$ & WNW to NW & $\begin{array}{l}\text { region of stress transition from strike } \\
\text { slip deformation in San Andreas to } \\
\text { extension in Basin and Range } \\
\text { province }\end{array}$ \\
\hline $\begin{array}{l}\text { Basin and Range-Rio } \\
\text { Grande rift }\end{array}$ & $\mathbf{N}(\mathbf{S S})$ & $\begin{array}{l}\text { WNW, locally } \\
\text { E-W and } \\
\text { NW }\end{array}$ & $\begin{array}{l}\text { region of active crustal spreading by } \\
\text { distributed normal and oblique slip } \\
\text { normal faulting; westermost part of } \\
\text { province exhibits both purely strike- } \\
\text { slip and purely normal faulting }\end{array}$ \\
\hline Colorado Plateau interior & $\mathbf{S S}+\mathbf{T}$ & NNE & $\begin{array}{l}\text { very low level of tectonic activity, } \\
\text { near-hydrostatic stress (?) }\end{array}$ \\
\hline $\begin{array}{l}\text { Snake River plain- } \\
\text { Yellowstone }\end{array}$ & $\mathbf{N}$ & NE to ENE & $\begin{array}{l}\text { smallest distinct stress province, } \\
\text { characterized by a least principal stress } \\
\text { direction parallel, not perpendicular, } \\
\text { to axis of plain }\end{array}$ \\
\hline $\begin{array}{l}\text { Hegben Lake-Centennial } \\
\text { Valley }\end{array}$ & $\mathbf{N}$ & $\mathbf{N}$ & $\begin{array}{l}\text { small anomalous region of N-S extension; } \\
\text { abrupt stress transition (over }<100 \mathrm{~km} \text { ) } \\
\text { to Snake River plain at Yellowstone }\end{array}$ \\
\hline $\begin{array}{l}\text { Northern Rocky } \\
\text { Mountains }\end{array}$ & $N+\mathbf{S S}$ & NE to E-W & $\begin{array}{l}\text { abundant late Tertiary normal faulting; } \\
\text { moderate level of modern seismic } \\
\text { activity }\end{array}$ \\
\hline Southern Great Plains & $\mathbf{N}$ & NNE & $\begin{array}{l}\text { very uniform stress orientation over } \\
\text { broad region }(800-1200 \text { ? } \mathrm{km}) \text {; abrupt } 90 \\
\text { change in least principal stress to Rio } \\
\text { Grande rift }(<50 \mathrm{~km})\end{array}$ \\
\hline Midcontinent & $\mathbf{T}+\mathbf{S S}$ & NW & $\begin{array}{l}\text { stable interior of the United States; } \\
\text { broad region of uniform NE-SW com- } \\
\text { pressive stress field; few earthquakes in } \\
\text { region show components of thrust and } \\
\text { strike slip motion }\end{array}$ \\
\hline Atlantic Coast & $\mathbf{T}$ & NE & $\begin{array}{l}\text { compression generally perpendicular to } \\
\text { continental margin and axis of Appala- } \\
\text { chian fold belt; faulting in Charleston, } \\
\text { S. C., area may be more complex }\end{array}$ \\
\hline Gulf Coast & $\mathbf{N}$ & WNW to $\mathbf{N}$ & $\begin{array}{l}\text { active listric normal faulting resulting } \\
\text { from sediment loading defines this pro- } \\
\text { vince; faults strike subparallel to } \\
\text { continental margin }\end{array}$ \\
\hline
\end{tabular}

"N, normal faulting; SS, strike slip faulting; and T, thrust faulting.

stress axes in the Pacific Northwest, however, appear somewhat oblique to those in areas to the south.

Available data on the transitions in orientation between different stress provinces indicate that these transitions can be abrupt and occur over $<75 \mathrm{~km}$, as in the Rio Grande rift and the southern Great Plains areas. Data from around the Colorado Plateau margins suggest the existence of a zone up to 150 $\mathrm{km}$ wide in which the two horizontal principal stresses are approximately equal in magnitude, and the direction of the least principal horizontal stress alternates between the two. Locally, in central Arizona the occurrence of normal and reverse focal mechanisms for similarily oriented fault planes suggests that all three principal stresses are approximately equal in magnitude.
There appear to be at least two ways in which the stress transition can occur: (1) by actual rotation of the stress field, as reported in the Hebgen Lake-Centennial Valley to Snake River plain-Yellowstone transition [Freidline et al., 1976; $\boldsymbol{R}$. B. Smith et al., 1977; Pitt et al., 1979] or (2) by a change in the relative magnitudes of the principal stresses, as seems to occur in the Basin and Range-Rio Grande rift to Colorado Plateau interior and the Rio Grande rift to southern Great Plains transitions.

In contrast to these abrupt stress transitions in the tectonically active western United States, in the eastern United States a broad zone $(\sim 200 \mathrm{~km})$ of stress transition may separate the region of predominantly NE-SW compression along the Atlantic Coast from the predominantly NE-SW compres- 
sion characterizing the Midcontinent region. While included here as part of the Midcontinent stress province, the Blue Ridge and Valley and Ridge provinces are characterized by scattered and locally contradictory stress orientations (Plates 1 and 2). The scatter may reflect the inherent uncertainties of the different methods used to determine stress or may represent a broad zone of transition in which the horizontal stresses are approximately equal in magnitude and the apparent stress field is more controlled by local inhomogeneities within the crust.

The relative magnitudes of the principal stresses were constrained on the basis of information from the measured magnitudes of in situ stress and from the current style of deformation within each region. In the western United States the high level of seismicity and broad zone of active faulting indicate generally large stress differences. In the eastern United States the seismicity is more locally concentrated, and whether the regions of high seismicity occur within localized zones of weakness or result from some mechanism producing local stress concentrations is unknown.

Two main styles of deformation can be broadly distinguished on the basis of the relative magnitudes of the principal stresses: (1) a predominantly extensional mode in which the least principal stress is near horizontal and remains invariant and (2) a predominantly compressional mode in which the greatest principal stress is horizontal and remains invariant. One end-member of the extensional mode is pure normal faulting, whereas pure thrust faulting is the corresponding end-member of the compressional mode. Pure strike slip faulting, such as occurs along much of the San Andreas fault (with the exception of the Big Bend area), represents the other end-member in both modes.

The available stress data often indicate a mixed style of faulting within a given stress province (Plate 2, Table 2). Regions characterized by extensional tectonics (normal and strike slip faulting) are found in the western United States and include: the Sierra Nevada, the Basin and Range-Rio Grande rift province, the northern Rocky Mountains, the Snake River plain, and local regions along the San Andreas fault near right-stepping en echelon offsets. Normal, growth faulting within the sedimentary section in the Gulf Coastal Plain probably results from a purely extensional stress regime. Regions of compressional tectonics (strike slip and thrust faulting) are located in the eastern and central as well as the western United States and include the Pacific Northwest, the Big Bend area of the San Andreas, the Colorado Plateau interior, the Atlantic Coast province, and the Midcontinent provinces.

The occurrence of a mixed style of faulting within a stress province with consistently oriented stress axes can be interpreted in several ways. Two of the principal stresses may be approximately equal in magnitude and minor regional variations in their relative values might determine the style of faulting; this is suggested by earthquakes along much of the western margin of the northern Basin and Range [e.g., Hamilton and Healy, 1969]. Alternately, while comparison of shallow (geologic data and in situ stress measurements) and deep (focal mechanisms) stress indicators within a stress province generally suggests that the orientations of the principal stress axes may remain unchanged throughout the upper crust, it is possible that the relative magnitudes of the principal stresses may vary markedly with depth. Crosson [1972] attributed the occurrence of shallow thrust events, deeper strike slip events, and very deep ( $\geq 60-\mathrm{km}$ depth) normal faults with similarily oriented stress axes in the Puget Sound area, Washington, to a more rapid increase with depth of the vertical stress relative to the horizontal stresses.

\section{Comparison With Heat Flow Data}

Figure 6 shows the map of least principal horizontal stress directions overlying the heat flow map of the United States by Lachenbruch and Sass [1977]. The map illustrates that the general level of heat flow is much higher in the West than in the East, that in the West the pattern of heat flow is much more complex and marked by large regional variations (the areas of both highest and lowest heat flow in the United States are in the West), and that abrupt transitions sometimes occur between the major heat flow provinces (cf. Lachenbruch and Sass [1977, 1978] and Blackwell [1978] for discussion of the heat flow provinces in the western United States). As mentioned above, similar features (a complex pattern, major regional variations, and abrupt transitions) also characterize the modern stress field in the western United States. In particular, a generally good correlation exists between the stress directions and heat flow data in the actively extending Basin and Range-Rio Grande Rift province and along its margins. This broad area of crustal rifting is characterized by a mean heat flow of $88 \mathrm{~mW} / \mathrm{m}^{2}$ ( $\left.2.1 \mathrm{HFU}\right)$, well above the continental mean of $63 \mathrm{~mW} / \mathrm{m}^{2}$ (1.5 HFU) [Lachenbruch and Sass, 1978].

A fairly good correlation exists between regions of high heat flow and the lateral extent of crustal extension, most notably along the Colorado Plateau margins, where the high heat flow and associated recent faulting and Quaternary volcanism extend well inward of the plateau physiographic boundary [Thompson and Zoback, 1979]. An area of the Colorado Plateau interior of relatively uniform average heat flow (63-67 mW/ $\left.\mathrm{m}^{2}, 1.5-1.6 \mathrm{HFU}\right)$ can be defined that resembles the Colorado Plateau interior defined on the basis of stress data [Reiter et al., 1979; Thompson and Zoback, 1979]. The correlation breaks down along the Rio Grande rift-southern Great Plains boundary in northern New Mexico, where a $90^{\circ}$ change in orientation stress transition is well controlled by data from Pliocene to Quaternary volcanic fields in both the Rio Grande rift and the southern Great Plains. As might be expected from the recent volcanism on the Great Plains, the region of high heat flow extends through that area, and the actual heat flow transition lies to the east. However, the available stress data suggest an extensional stress regime in the southern Great Plains with $\sim$ NNE-SSW direction of extension, as opposed to the much more active WNW-ESE extension in the Rio Grande rift.

New data on heat flow in the Mojave block (San Andreas stress province) are quite uniform and reveal a mean heat flow of $67 \mathrm{~mW} / \mathrm{m}^{2}$ (1.6 HFU) [Lachenbruch et al., 1978]. The heat flow rises sharply to the east along a north-northwest trending boundary that coincides with the eastern limit of active seismicity and a change from predominantly strike slip to normal faulting within the Basin and Range province.

Lachenbruch and Sass [1978] have developed thermomechanical models compatible with observed extension rates to explain the high surface heat flow in the Basin and Range province. These models, which require convection (either solid state or by magmatic intrusion) in the crust and uppermost mantle, are consistent with gravity data which require that an influx of mass must accompany the horizontal extension in this province [Thompson and Burke, 1974]. Such shallow level thermal sources are consistent with abrupt heat 


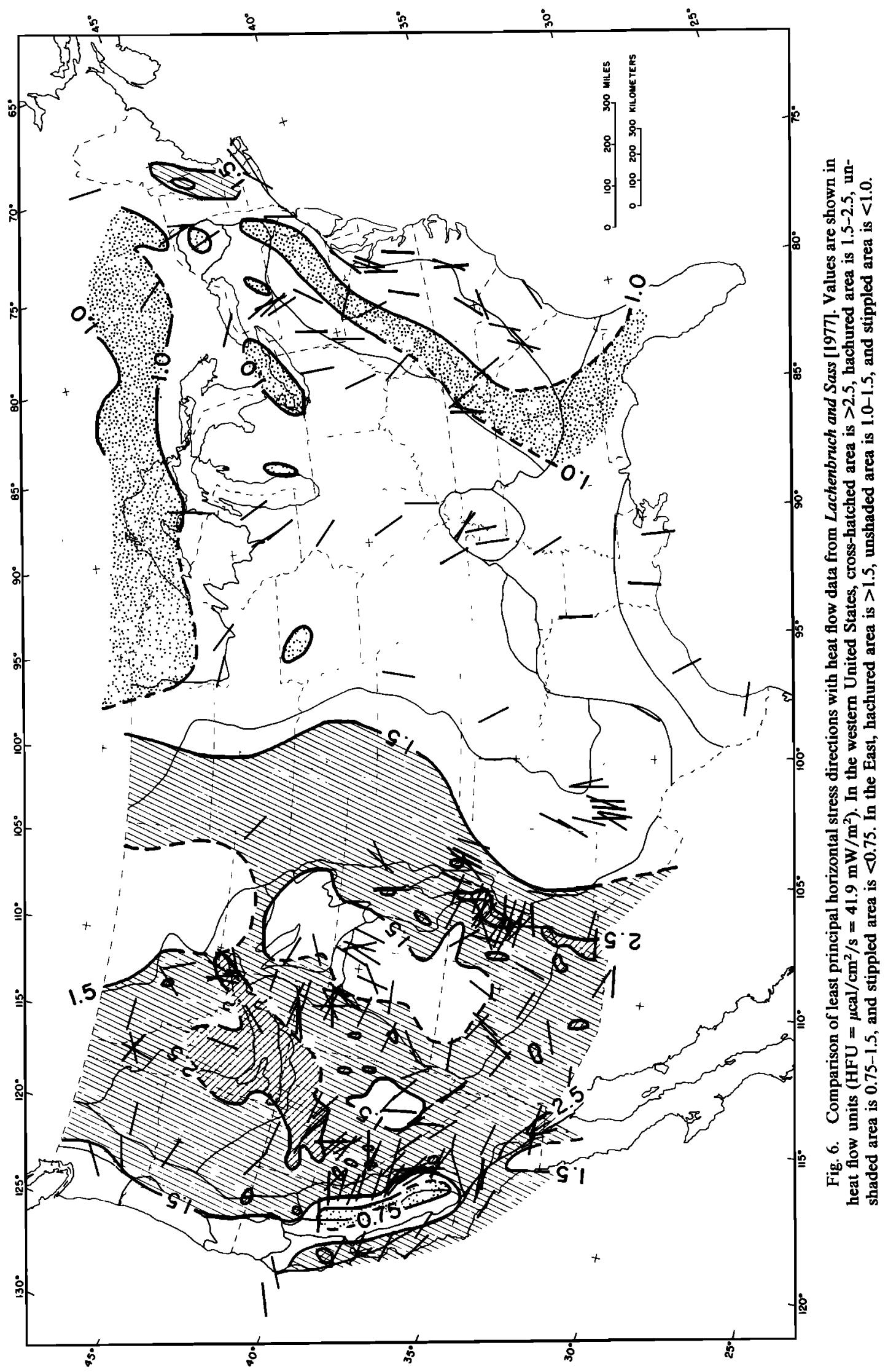




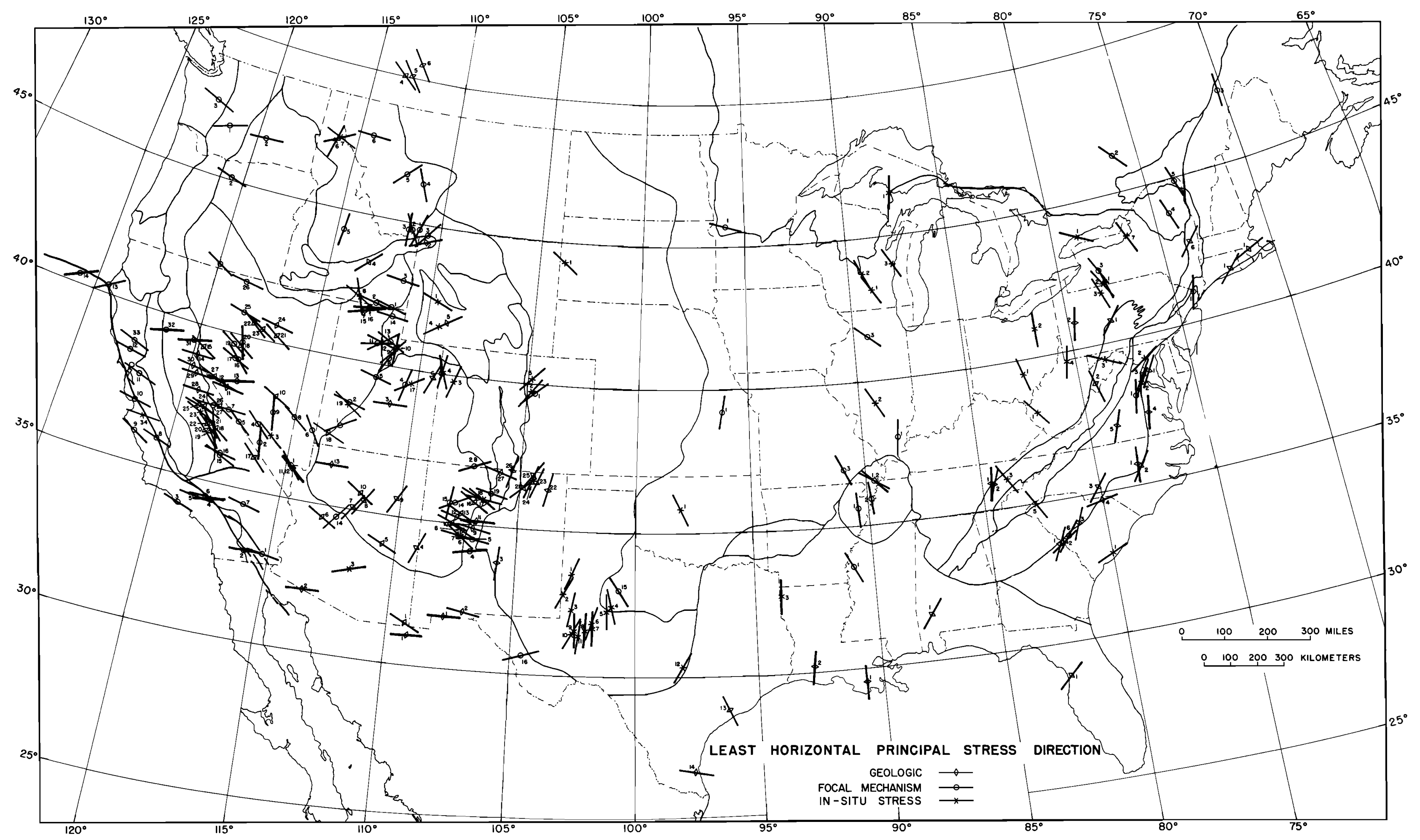

Plate 1. Map of conterminous United States, showing least compressive horizontal principal stress directions. Physiographic provinces are shown for reference. Numbers refer to corresponding state numbers in Table 1. 


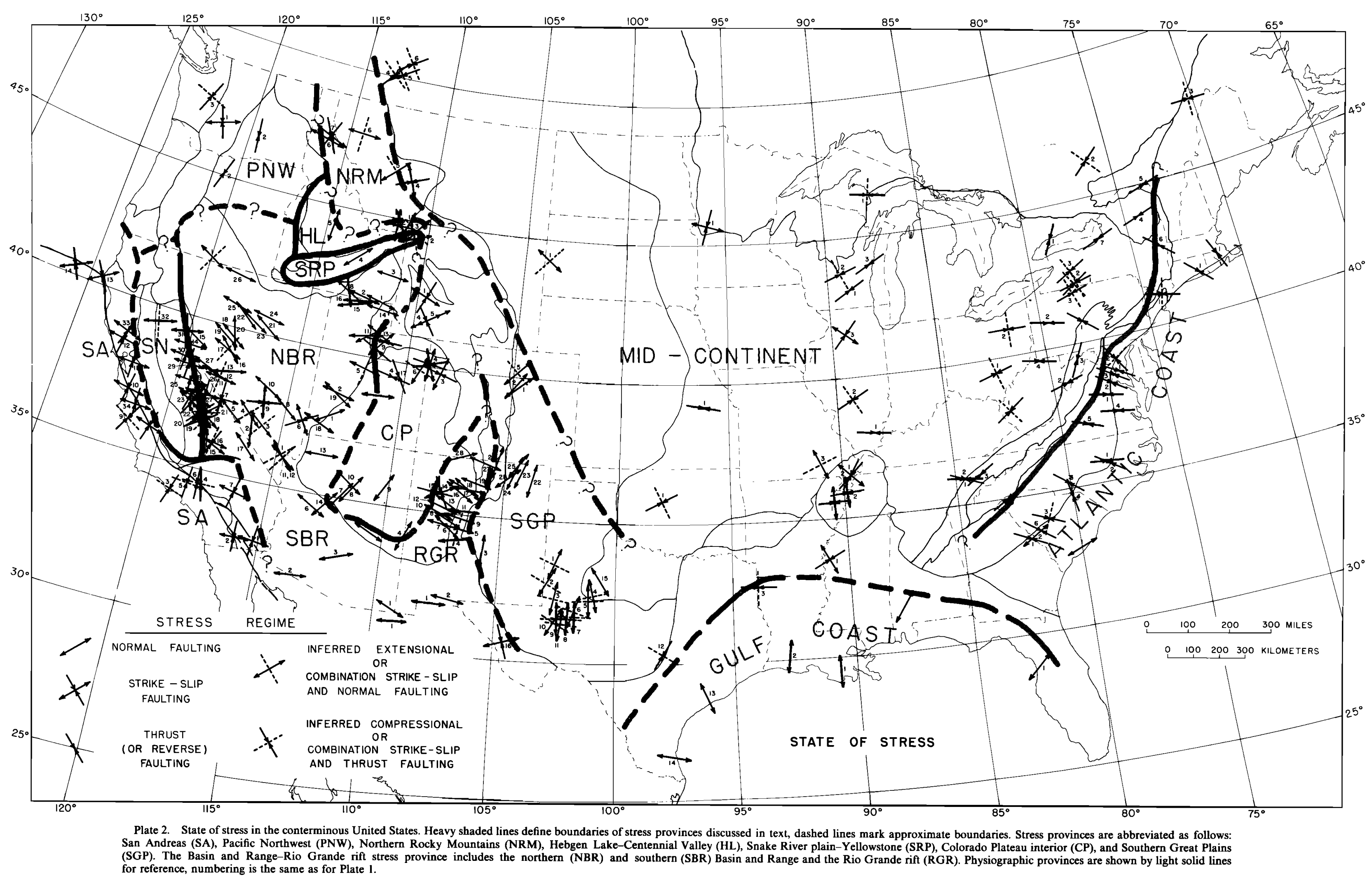


flow transitions along the margins of the Basin and RangeRio Grande rift province. The Sierra Nevada to Basin and Range heat flow transition has been found to occur over $<20$ km in places [Sass et al., 1971; A. H. Lachenbruch, oral communication, 1979]. Although data on the eastern Basin and Range-Colorado Plateau heat flow transition are sparse, the available data limit this transition to $<75 \mathrm{~km}$ [Thompson and Zoback, 1979]. The Colorado Plateau-Rio Grande rift heat flow transition is also abrupt and occurs over $<\sim 50 \mathrm{~km}$ [Reiter et al., 1975; Thompson and Zoback, 1979].

These abrupt heat flow transitions are consistent with the abrupt stress transition found along the margins of actively extending regions and indicate shallow sources (crust or uppermost mantle) for both the extensional stresses and the heat. The excellent correlation in both the pattern of the heat flow and stress data and the abrupt transitions between provinces suggests that the stresses related to rifting are intimately linked to the thermal processes.

Regional variations in heat flow with the eastern United States are generally small. These variations are believed to be nontectonic in origin and to arise from variations in radioactive heat generation [Birch et al., 1968; Diment et al., 1972]. However, one thermal anomaly of possible tectonic origin in the East has been identified by Swanberg et al. [1979] in the New Madrid (Northern Mississippi Embayment) on the basis of slightly elevated heat flow values and bottom hole temperature measurements. The absolute values of the heat flow (55-67 mW/m², 1.3-1.6 HFU) are not, however, sufficiently above the midcontinental mean to qualify as a major heat flow anomaly. Swanberg et al. favored the interpretation of a small convective heat flow component, resulting from deep groundwater circulation along upper crustal fractures associated with the active faulting in that region to explain the local thermal anomaly. Although silica geothermometry data suggest a possible thermal anomaly in the Charleston, South Carolina, area [Swanberg and Morgan, 1978], heat flow measured in a 790-m-deep well near the epicenter of the 1866 Charleston earthquake was 1.3 HFU (Sass and Ziagos, 1977], similar to measurements made in surrounding areas.

\section{CONCLUDING REMARKS}

Using a variety of techniques to determine principal stress orientations, regional patterns of the in situ stress field of the conterminous United States have been defined. Within a given region, stress orientations inferred from geologic observations, earthquake source mechanisms, and direct measurement of in situ stress are generally consistent (within the accuracy ot the techniques) despite the different depth intervals sampled. This implies a relatively uniform upper crustal stress field which can be investigated by making measurements at relatively shallow depths. Stress provinces with consistent principal stress orientations and relative magnitudes can be delineated; these stress provinces have linear dimensions that range from 100 to $2000 \mathrm{~km}$.

With the exception of normal 'growth' faulting within the sedimentary section on the Gulf Coastal Plain the central and eastern United States are dominated by compressional tectonism, generally NW-SE compression along the Atlantic Coast and $\sim$ NE-SW compression within the midcontinent area. Whereas broad regions of the western United States are characterized by extensional and strike slip style tectonism, the Pacific Northwest, the Colorado Plateau interior, and the Big Bend area along the San Andreas fault are dominated by compressional deformation.
Much of the complex pattern of stress in the western United States can be attributed to present transform motion between the Pacific and North American plates and residual effects of past subduction along the western edge of the North American plate. Dynamic effects related to the gradual cessation of subduction and development of transform faulting may have resulted in the anomalously hot upper mantle underlying much of the western United States. This hot upper mantle replaced the volume of mantle previously occupied by a subducted lithospheric slab [e.g., Dickinson and Snyder, 1979]. The modern state of stress in the Basin and Range province is apparently largely the result of superposition of dextral shear on a back arc extensional stress field initiated in Miocene time. Anomalous patterns in the western United States, notably WNW-ESE compression within the Colorado Plateau interior and NNE-SSW extension within the southern Great Plains area, may represent complex second-order effects related to the active kinematics of the surrounding regions.

The observed pattern of stress in the central and eastern United States can be used to constrain proposed mechanisms of intraplate stress. The roughly NE-SW compression in the Midcontinent stress province is generally consistent with either ridge push or asthenospheric viscous drag resistance to plate motion. However, drag resistance directions correlate better with the stress data than do ridge push directions, suggesting that drag may be the primary source of stress in the Midcontinent province. Calculated magnitudes of shear stress at the base of the lithosphere derived from a drag mechanism are typically only a few bars [e.g., Chappel and Tullis, 1977]; however, accumulating evidence from xenolith studies indicates that stresses in the upper mantle may be of the order of a hundred bars [Mercier, 1980]. Also, a poorly developed low-velocity zone [Herrin, 1972] and a thick cold lithosphere under cratonic regions may explain why viscous drag resistance may be an important mechanism for slow moving continents.

Asthenospheric counterflow models, whose effects have been suggested to be 2-3 times that of simple drag resistance to plate motion [cf. Chase, 1979; Hager and O'Connell, 1979], do not apply; predicted stress orientations are nearly $90^{\circ}$ from those observed in the Midcontinent province. Perhaps major variations in lithospheric thickness act to 'channel' this counterflow and present models which assume a worldwide uniformly thick lithosphere are too simplistic.

Sources of stress in the Atlantic Coast region remain unresolved. Calculated ridge push and drag resistance directions are $30^{\circ}-80^{\circ}$ oblique to inferred stress orientations and indicate that if ridge push is an important force providing compression across the Atlantic Coast region, additional effects must be superimposed to explain the observed direction of maximum horizontal compression. The orientation of this compression, approximately perpendicular to both the continental margin and the Appalachian Fold Belt, suggests a causal relationship. Lateral density contrasts associated with crustal structure at a passive continental margin predict extension perpendicular to the continental margin rather than the observed compression. Lithospheric flexure resulting from sediment loading also predicts extension on the continental margin. Stresses derived from major lithospheric thickening along the edge of the continent also appear unlikely; presently available seismic data suggest little contrast in thickness between the coastal plain lithosphere and the adjacent 180-190 m.y. old oceanic lithosphere. Lithospheric structure under the Appalachian Fold Belt, however, remains unexamined. Postu- 
lated southeastward directed gravity backsliding of the Appalachians along a major detachment, while capable of explaining the observed orientation of compressive stress within the Atlantic Coast province, is inconsistent with evidence of compressional tectonism (Recent thrust faulting) in the main elevated core of the Appalachians. Rotation of stress (or strain) by anisotropic basement structure and flexural effects in response to erosion and deglaciation are suggested as possible influences on the stress field.

Transitions between stress provinces also help constrain sources of stress. The abrupt transitions observed in the orientation or magnitude of in situ stresses in the western United States imply a shallow (crustal or uppermost mantle) source for these stresses. These abrupt transitions are found only in areas of active extensional tectonics (Basin and Range, Rio Grande rift, Snake River plain). The accompanying high heat flow in these areas also shows abrupt transitions and thus similarly implies sources in the crust or uppermost mantle. The excellent correlation of heat flow with stress orientations in these regions indicates that the stresses related to rifting are intimately linked to the thermal processes. In the relatively quiescent eastern United States a possibly broad region of stress transition suggests stresses derived from broad-deep sources. Both asthenospheric drag resistance to plate motion and transmitted ridge push reflect such sources. In terms of broad-deep sources of stress the apparent complexity of the stress field in the transition zone is not unexpected; it may be controlled in part by local preexisting structure.

A final note should be added on the time scale of changes of regional stress fields. As we appeal to broad scale plate tectonic forces to explain much of the regional stress patterns, it is likely that stress fields derived from these forces could persist for a period of time similar to the lengths of time between major plate reorganizations. In the Atlantic Coast region the consistent style of observed fault offsets along this passive margin suggests a similar stress field (both orientation and relative magnitude) for the past $\simeq 110$ m.y. [D. C. Prowell, written communication, 1980; Wentworth and Mergner-Keefer, 1980]. In areas of active tectonism adjacent to plate boundaries, such as the western United States, the stress field may change as often as changes in relative motions or plate boundaries occur. In the Basin and Range province, evidence exists of $\sim 45^{\circ}$ clockwise change in the least principal stress orientation since middle Miocene time [M. L. Zoback and G. $A$. Thompson, 1978]; detailed data in several areas suggest that this change occurred between $\sim 14$ and 7 m.y. B.P. The general trend of the largely post-10 m.y. ranges in the northern Basin and Range, roughly perpendicular to the modern least principal stress direction, suggests that this change may have occurred rapidly (>4 m.y.?). On a similar time scale, tectonism in the Columbia Plateau region (within the Pacific Northwest) changed from a major episode of $\sim \mathrm{E}-\mathrm{W}$ extension coinoiding with eruption of the Columbia River flood basalts 14 17 m.y. B.P. to Pliocene to Quaternary tectonism dominated by N-S compression.

Acknowledgments. We are indebted to the numerous workers whose efforts over the years have produced the data used in this compilation. The manuscript was greatly improved by critical reviews and comments by Art McGarr, Randy Richardson, Bill Brace, Hans Swolfs, George Thompson, Bob Smith, Russ Wheller, Marc Sbar, and Art Tarr. We thank John Sass for allowing us to use the heat flow map, Bob Smith for the map of western United States seismicity, and James E. York and Jack Oliver for the earthern United States seismicity map.

\section{REFERENCES}

Abou-Sayed, A. S., C. E. Brechtel, and R. J. Clifton, In situ stress determination by hydrofracturing: A fracture mechanics approach, $J$. Geophys. Res., 83(B6), 2851-2862, 1978.

Aggarwal, Y. P., and L. R. Sykes, Earthquakes, faults, and nuclear power plants in southern New York, Science, 200, 425-429, 1978.

Aggarwal, Y. P., J. P. Yang, and E. Cranswick, Seismological investigation in the Adirondacks and environs (abstract), Geol. Soc. Amer. Abstr. Program, 9, 234, 1977.

Aggson, J., Report on in situ determination of stresses, Mather Mine, Ishpenning, Michigan, Prog. Rep. DMRC 10006, U.S. Bur. of Mines, Denver, Colo., 1972.

Aggson, J. R., and V. E. Hooker, In-situ rock stress determination: Techniques and applications, in Underground Mining Handbook Society of Mining Engineers of AIME, New York, in press, 1980.

Akers, J. P., J. C. Shorty, and P. R. Stevens, Hydrogeology of the Cenozoic igneous rocks, Navajo and Hopi Indian reservations, Arizona, New Mexico, and Utah, U.S. Geol. Surv. Prof. Pap., 521-D, 18 pp., 1971.

Anderson, C. A., E. A. Scholz, and J. D. Strobell, Jr., Geology and ore deposits of the Bagdad area, Yavapai County, Arizona, U.S. Geol. Surv. Prof. Pap., 278, 103 pp., 1955.

Anderson, E. M., The Dynamics of Faulting and Dyke Formation With Applications to Britain, 2nd ed., 206 pp., Oliver and Boyd, Edinburgh, 1951.

Angelier, J., Determination of the mean principal directions of stresses for a given fault population, Tectonophysics, 56, T17-26, 1979.

Arabasz, W. J., R. B. Smith, and W. B. Richins, Earthquake studies along the Wasatch Front, Utah: Network monitoring, seismicity, and seismic hazards, in Earthquake Studies in Utah, 1850 to 1978, edited by W. J. Arabasz, R. B. Smith, and W. D. Richins, pp. 253286, University of Utah, Salt Lake City, 1979.

Armstrong, R. L., W. P. Leeman, and H. E. Malde, K-Ar dating, Quaternary and Neogene volcanic rocks of the Snake River plain, Idaho, Amer. J. Sci., 275, 225-251, 1975.

Artyushkov, E. V., Stresses in the lithosphere caused by crustal thickness inhomogeneities, J. Geophys. Res., 78, 7675-7708, 1973.

Atwater, T., Implications of plate tectonics for the Cenozoic tectonic evolution of western North America, Geol. Soc. Amer. Bull., 81, 3513-3535, 1970.

Atwater, T., and P. Molnar, Relative motion of the Pacific and North American plates deduced from sea-floor spreading in the Atlantic, Indian, and South Pacific oceans, Proceedings of the Conference on Tectonic Problems of the San Andreas Fault System, Stanford Univ. Publ. Geol. Sci., 13, 136-148, 1973.

Babcock, E. A., Measurement of subsurface fractures from dipmeter logs, Amer. Ass. Petrol. Geol. Bull., 62, 1111-1126, 1978.

Babenroth, D. L., and A. N. Strahler, Geomorphology and structure of the East Kaibab monocline, Arizona and Utah, Geol. Soc. Amer. Bull., 56, 107-150, 1945.

Bache, T. C., and D. G. Lambert, Earthquake ground motion from the 1975 Pocatello Valley earthquake, Rep. SSS-R-78-3507, $43 \mathrm{pp}$. Syst., Sci. and Software, La Jolla, Calif., 1977.

Bailey, J. P., Seismicity and contemporary tectonics of the Hegben Lake-Centennial Valley, Montana area, M.S. thesis, Univ. of Utah, Salt Lake City, 1976.

Baldwin, B., and W. R. Muehlberger, Geologic studies of Union County, New Mexico, N. Mex. Bur. Mines Miner. Resour. Bull., 63, 171 pp., 1959.

Balk, R., Geologic map and sections of Tres Hermanas Mountains, Geol. Map 16, N. Mex. Bur. of Mines Miner. Resour., Socorro, 1962.

Bateman, P. C., Willard D. Johnson and the strike-slip component of fault movement in the Owens Valley, California, earthquake of 1872, Bull. Seismol. Soc. Amer., 51, 483-493, 1971.

Bell, J. S., and D. I. Gough, Northeast-southwest compressive stress in Alberta: Evidence from oil wells, Earth Planet. Sci. Lett., 45, 475-482, 1979.

Behrendt, J. C., R. M. Hamilton, H. D. Ackerman, V. J. Henry, and K. C. Bayer, Cenozoic reactivation of faulting in the vicinity of Charleston, S. C., earthquake zone, submitted to Geology, 1980.

Best, M. G., and W. K. Hamblin, Origin of the northern Basin and Range province: Implications from the geology of its eastern boundary, Cenozoic Tectonics and Regional Geophysics of the Western Cordillera, Geol. Soc. Amer. Mem., 152, 313-340, 1978. 
Bickel, D. L., and D. R. Dolinar, In situ determination of stresses, Lakeshore Mine, Casa Grande, Arizona, Prog. Rep., DMRC 10018, U.S. Bur. of Mines, Denver, Colo., 1976.

Birch, F., R. F. Roy, and E. R. Decker, Heat flow and thermal history in New England and New York, in Studies of Appalachian Geology: Northern and Maritime, edited by E. Zen et al., pp. 437-451, John Wiley, New York, 1968.

Biswas, N. N., and L. Knopoff, The structure of the upper mantle under the United States from the dispersion of Rayleigh waves, Geophys. J. Roy. Astron. Soc., 36, 515-539, 1974.

Blackwell, D. D., Heat flow and energy loss in the western United States, Cenozoic Tectonics and Regional Geophysics of the Western Cordillera, Geol. Soc. Amer. Mem., 152, 175-208, 1978.

Blake, M. C., Jr., R. H. Campbell, T. W. Dibblee, Jr., D. G. Howell, T. H. Nilsen, W. R. Normark, J. C. Vedder, and E. A. Silver, Neogene basin formation in relation to plate-tectonic evolution of San Andreas fault system, California, Amer. Ass. Petrol. Geol. Bull., 62, 344-372, 1978.

Block, J. W., R. C. Clement, L. R. Lew, and J. de Boer, Recent thrust faulting in southeastern Connecticul, Geology, 7, 79-82, 1979.

Bollinger, G. A., A microearthquake survey of the central Virginia seismic zone, Earthquake Notes, 46, 3-13, 1975.

Bollinger, G. A., Seismicity of the southeastern United States, Bull. Seismol. Soc. Amer., 63, 1785-1808, 1973.

Bolt, B., C. Lomnitz, and T. V. McEvilly, Seismological evidence on the tectonics of central and northern California and the Mendocino escarpments, Bull. Seismol. Soc. Amer., 58, 1725-1767, 1968.

Both, M. H. P., and D. S. Dean, Stress systems at young continental margins, Nature, 235, 23-25, 1972.

Bredehoeft, J. D., R. G. Wolf, W. S. Keys, and E. Shuter, Hydraulic fracturing to determine the regional in situ stress field, Piceance Basin, Colorado, Geol. Soc. Amer. Bull., 87, 250-258, 1976.

Bridwell, R. J., Lithospheric thinning and the late Cenozoic thermal and tectonic regime of the northern Rio Grande Rif, $N$. Mex. Geol. Soc. Field Conf. Guideb., 27, 283-292, 1976.

Brown, L. D., P. A. Krumhansl, C. E. Chapin, A. R. Sanford, F. A Cook, S. Kaufman, J. E. Oliver, and F. S. Schilt, COCORP seismic reflection studies of the Rio Grande Rift, in Rio Grande Rift: Tectonics and Magmatism, edited by R. E. Riecker, pp. 169-184, AGU, Washington, D. C., 1979.

Brumbaugh, D. S., Analysis of the Williams, Arizona earthquake of November 4, 1971, Bull. Seismol. Soc. Amer., 70, 885-891, 1980.

Bufe, C. G., S. M. Marks, F. W. Lester, R. S. Ludwin, and M. C Stickney, Seismicity of the Geysers-Clear Lake geothermal area California, U.S. Geol. Surv. Prof. Pap., in press, 1980.

Byerly, P., The Montana earthquake of June 28, 1925, G.M.C.T. Bull. Seismol. Soc. Amer., 16, 209-263, 1926.

Carey, E., Computation of principal stress axes associated with observed motions on fault planes, Rev. Geol. Dyn. Geogr. Phys., 21, $57-66,1979$.

Carr, W. J., Summary of tectonic and structural evidence for stress orientation at the Nevada Test Site, Open File Rep. 74-176, 53 pp., U.S. Geol. Surv., Reston, Va., 1974.

Chan, S. S. M., and T. J. Crocker, A case study of in situ rock deformation behavior in the Silver Summit Mine, Coeur D'Alene mining district, in Proceedings of the 7th Canadian Rock Mechanics Symposium, Edmonton, 1971, pp. 135-160, Mines Branch, Department of Energy, Mines and Resources, Ottawa, 1972.

Chapin, C. E., and W. R. Seager, Evolution of the Rio Grande rift in the Socorro and Las Cruces area, in N. Mex. Geol. Soc. Field Conf. Guideb., 26, 297-321, 1975.

Chapman, D. S., and H. N. Pollock, Regional geotherms and lithospheric thickness, Geology, 5, 265-268, 1977.

Chapple, W. M., and T. E. Tullis, Evaluation of the forces that drive the plates, J. Geophys. Res., 82(14), 1967-1984, 1977.

Chase, C. G., Asthenospheric counterflow: A kinematic model, Geophys. J. Roy. Astron. Soc., 56, 1-18, 1979.

Christiansen, R. L., and E. H. McKee, Late Cenozoic volcanic and tectonic evolution of the Great Basin and Columbia Intermountain regions, Cenozoic Tectonics and Regional Geophysics of the Western Cordillera, Geol. Soc. Amer. Mem., 152, 283-312, 1978.

Colton, H. S., The basaltic cinder cones and lava flows of the San Francisco Mountain volcanic field, report, 58 pp., Mus. of N. Ariz., Flagstaff, Ariz., 1967.

Cook, F. A., D. S. Albaugh, L. D. Brown, S. Kaufman, J. E. Oliver, and R. D. Hatcher, Jr., Thin-skinned tectonics in the crystalline southern Appalachians; COCORP seismic-reflection profiling of the Blue Ridge and Piedmont, Geology, 7, 563-567, 1979.

Cooper, J. B., and E. C. John, Geology and ground water occurrence in southeastern McKinlay County, New Mexico, N. Mex. State Eng. Tech. Rep., 35, 108 pp., 1968.

Copeland, C. W., Faults in Tertiary rocks of southwestern Alabama, Cretaceous and Tertiary Faults in Southwestern Alabama, pp. 1657, Guideb. Annu. Field Trip 14th, Ala. Geol. Soc., University, 1976.

Cordell, L., Regional geophysical setting of the Rio Grande rift, Geol. Soc. Amer. Bull., 89, 1073-1090, 1978.

Couch, R., G. Thrasher, and K. Keeling, The Deschutes Valley earthquake of April 12, 1976, Ore Bin, 38, 151-161, 1976.

Cox, J. W., The high resolution dipmeter reveals dip-related borehole and formation characteristics, paper presented at the 11th Annua Logging Symposium, Soc. Prof. Well Log Anal., Los Angeles, Calif., 1970.

Crosson, R. S., Small earthquakes, structure, and tectonics of the $\mathbf{P u -}$ get Sound region (Washington), Bull. Seismol. Soc. Amer., 62, 1133-1171, 1972.

Crosson, R. S., and J.-W. Lin, A note on the Mt. Rainier earthquake of April 20, 1974, Bull. Seismol. Soc. Amer., 65, 549-552, 1975.

Dames and Moore, Summary report on the in-progress seismic monitoring program at the North Anna Site, January 21, 1974 through May 1, 1976, submitted to the Nuclear Regulatory Commission, Washington, D. C., 1976

Daniels, R. B., and E. E. Gamble, Atlantic Coastal Plains Geological Association Field Trip Guidebook, vol. 13, 36 pp., Carolina Geological Society, Raleigh, N. C., 1972.

Davis, G. A., Tectonic evolution of the Pacific Northwest: Precambrian to present, Subappendix 2R C of preliminary safety analysis report, Amendment 23, Nuclear Project No. 1, p. i-2Rc-46, Wash. Public Power Supply Syst., 1977.

Davis, G. A., Problems of intraplate extensional tectonics, western United States, with special emphasis on the Great Basin, in 1979 Basin and Range Symposium, edited by G. W. Newman and H. D. Goode, pp. 41-54, Rocky Mountain Association of Geologists and Utah Geological Association, Denver, Colo., 1979.

Davis, G. A., and B. C. Burchfiel, Garlock fault: An intracontinental transform structure, southern California, Geol. Soc. Amer. Bull, 84, 1407-1422, 1973.

Dewey, J. W., W. M. Dillinger, J. Taggart, and S. T. Algermissen, A technique for seismic zoning: Analysis of earthquake locations and mechanisms in northern Utah, Wyoming, Idaho, Montana, in Proceedings of the International Conference on Microzonation for Safer Construction, Research and Application, vol. 2, pp. 879-895, Washington University, St. Louis, Mo., 1972.

Dibblee, T. W., Jr., Areal geology of the western Mojave Desert, California, U.S. Geol. Surv. Prof. Pap., 522, 153 pp., 1967.

Dickinson, W. R., and W. S. Snyder, Geometry of subducted slabs related to San Andreas transform, J. Geol., 87, 609-627, 1979.

Diment, W. H., T. C. Urban, and F. A. Revetta, Some geophysical anomalies in the eastern United States, in The Nature of the Solid Earth, edited by F. C. Robertson, pp. 544-572, McGraw-Hill, New York, 1972.

Donnelly, M. F., Geology of the Sierra del Pinacate volcanic field, northern Sonora, Mexico, and southern Arizona, U.S.A., Ph.D. thesis, 722 pp., Stanford Univ., Stanford, Calif., 1974.

Duffield, W. A., Late Cenozoic ring faulting and volcanism in the Coso Range area of California, Geology, 3, 335-338, 1975.

Dumas, D. B., H. J. Dorman, and G. V. Latham, A reevaluation of the August 16, 1931 Texas earthquake, Bull. Seismol. Soc. Amer., $70,1171-1180,1980$.

Eaton, G. P., A plate tectonic model for late Cenozoic crustal spreading in the western United States, in Rio Grande Rift: Tectonics and Magmatism, edited by R. E. Riecker, pp. 7-32, AGU, Washington, D. C., 1979.

Eaton, G. P., Geophysical and geological characteristics of the crust of the Basin and Range province, in Continental Tectonics; National Research Council Studies in Geophysics, edited by B. C. Burchfiel, L. T. Silver, and J. E. Oliver, pp. 96-113, National Academy of Sciences, Washington, D. C., 1980.

Eaton, G. P., R. L. Christiansen, H. M. Iyer, A. M. Pitt, D. R. Mabey, H. R. Blank, Jr., I. Zietz, and M. E. Gettings, Magma beneath Yellowstone National Park, Science, 188, 787-796, 1975.

Eaton, G. P., R. R. Wahl, H. J. Prostka, D. R. Mabey, and M. D. 
Kleinhopf, Regional gravity and tectonic patterns: Their relation to late Cenozoic epeirogeny and lateral spreading in the western Cordillera, Cenozoic Tectonics and Regional Geophysics of the Western Cordillera, Geol. Soc. Amer. Mem., 152, 51-91, 1978.

Eberhart-Phillips, D. M., M. L. Sbar, R. M. Richardson, and R. B. Herrmann, Analysis of the 4 February 1976 Chino Valley, Arizona earthquake (abstract), Eos Trans. $A G U, 60,894,1979$.

Eberly, L. D., and T. B. Stanley, Jr., Cenozoic stratigraphy and geologic history of southwestern Arizona, Geol. Soc. Amer. Bull., 89, 921-940, 1978.

Ellsworth, W. L., and S. M. Marks, Seismicity of the Livermore Valley, California region, 1969-1979, Open File Rep. 80-515, 42 pp., U.S. Geol. Surv., Reston, Va., 1980.

Elston, W. E., and T. J. Bornhorst, The Rio Grande rift in context of regional post-40 m.y. volcanic and tectonic events, in Rio Grande Rift: Tectonics and Magmatism, edited by R. E. Riecker, pp. 416438, AGU, Washington, D. C., 1979.

Fenneman, N. M., Physical divisions of the United States, map, 1:7,000,000 scale, U.S. Geol. Surv., Reston, Va., 1946.

Finnell, T. L., Geologic map of the Chediski Peak quadrangle, Navajo County, Arizona, Quad. Map GQ-544, U.S. Geol. Surv., Reston, Va., 1966.

Fischer, F. G., P. J. Papanek, and R. M. Hamilton, The Massachusetts Mountain earthquake of 5 August 1971 and its aftershocks, Nevada Test Site, Rep. USGS-474-149, 16 pp., U.S. Geol. Surv., Reston, Va., 1972. (Available from U.S. Department of Commerce, National Technical Information Service, Springfield, $\mathbf{V a}$.)

Fletcher, J. B., and L. R. Sykes, Earthquakes related to hydraulic mining and natural seismic activity in western New York State, $J$. Geophys. Res., 82, 3767-3780, 1977.

Frank, F. C., Plate tectonics, the analogy with glacier flow and isostasy, in Flow and Fracture of Rocks, Geophys. Monogr. Ser., vol. 16, edited by H. C. Heard et al., pp. 285-292, AGU, Washington, D. C., 1972 .

Freidline, R. A., R. B. Smith, and D. D. Blackwell, Seismicity and contemporary tectonics of the Helena, Montana area, Bull. Seismol. Soc. Amer., 66, 81-95, 1976.

Gawthrop, W. H., Seismicity and tectonics of the central California coastal region, M.S. thesis, 76 pp., Univ. of Colo., Boulder, 1977.

Graham, T., and E. F. Chiburis, Fault plane solutions and the state of stress in New England, Earthquake Notes, 31, in press, 1980.

Griggs, R. L., Geology and ground-water resources of the eastern part of Colfax County, New Mexico, N. Mex. Bur. Mines Min. Resour. Ground Water Rep., I, 180 pp., 1948.

Grose, L. T., Late Quaternary tectonic controls of occurrence of geothermal systems in Gerlach-Hualapai Flat area, northwestern Nevada, Colo. Sch. Mines Quart., 73(3), 11-14, 1978.

Gumper, F. J., and C. Scholz, Microseismicity and tectonics of Nevada Seismic Zone, Bull. Seismol. Soc. Amer., 61, 1413-1432, 1971.

Hack, J. C., Sedimentation and volcanism in the Hopi Buttes, Arizona, Geol. Soc. Amer. Bull., 53, 335-372, 1942.

Hack, J. T., Rock control and tectonism-Their importance in shaping the Appalachian Highlands, U.S. Geol. Surv. Prof. Pap., 1126$B, 1979$.

Hager, B. H., and R. J. O'Connell, Kinematic models of large-scale flow in the earth's mantle, $J$. Geophys. Res., 84, 1031-1048, 1979.

Haimson, B. C., Earthquake related stresses at Rangely, Colorado, in New Horizons in Rock Mechanics: Proceedings, 14th Symposium on Rock Mechanics, edited by H. R. Hardy, Jr., and R. Stefanko, pp. 689-708, American Society of Civil Engineers, New York, 1973.

Haimson, B. C., A simple method for estimating in situ stresses at great depths, Field Testing and Instrumentation of Rock, Spec. Tech. Publ., 554, pp. 156-182, Amer. Soc. for Test. Mater., Philadelphia, Pa., 1974a.

Haimson, B. C., Stress measurements in faults and their vicinities, semiannual report, Grant 14-08-0001-6118, U.S. Geol. Surv., Reston, Va., $1974 b$.

Haimson, B. C., Preexcavation deep-hole stress measurements for design of underground chambers - Case histories, in Proceedings of the 1976 Rapid Excavation and Tunneling Conference, edited by $\mathbf{R}$. J. Robins and R. J. Conlon, pp. 699-714, Society of Mining Engineers of AIME, New York, 1976.

Haimson, B. C., A stress measurement in West Virginia and the state of the stress in southern Appalachians (abstract), Eos Trans. $A G U$, $58,493,1977 a$.

Haimson, B. C., Crustal stress in the continental United States as derived from hydrofracturing tests, in The Earth's Crust, Geophys.
Monogr. Ser., vol. 20, edited by J. C. Heacock, pp. 576-592, AGU, Washington, D. C., $1977 b$.

Haimson, B. C., Near-surface and deeper hydrofracturing stress measurements in the Waterloo quartzite (abstract), Eos Trans. $A G U, 59$, $327-328,1978 a$.

Haimson, B. C., Additional stress measurements in the Michigan Basin (abstract), Eos Trans. AGU, 59(12), 1209, 1978b.

Haimson, B. C., New hydrofracturing measurements in the Sierra Nevada Mountains and the relationship between shallow stresses and surface topography, paper presented at the 20th U.S. Symposium on Rock Mechanics, U.S. Natl. Comm. for Rock Mech., Austin, Tex., 1979.

Haimson, B. C., and C. Fairhurst, In-situ stress determination at great depth by means of hydraulic fracturing, in Rock Mechanics-Theory and Practice, Proceedings, 11th Symposium on Rock Mechanics, Berkeley, 1969, chap. 28, edited by W. H. Somerton, pp. 559-584, Society of Mining Engineers of AIME, New York, 1970.

Haimson, B. C., and C. F. Lee, Stress measurements in underground nuclear slant design, in Proceedings of 1979 Rapid Excavation and Tunneling Conference, Atlanta, Georgia, Society of Mining Engineers of AIME, Littleton, Colo., 1979.

Haimson, B. C., J. Lacomb, A. H. Jones, and S. J. Green, Deep stress measurements in tuff at the Nevada Test Site, in Advances in Rock Mechanics, vol. IIa, pp. 557-561, National Academy of Sciences, Washington, D. C., 1974.

Hales, A. L., Gravitational sliding and continental drift, Earth Planet. Sci. Lett., 6, 31-34, 1969.

Hamilton, R. M., Aftershocks of the Borrego Mt. earthquake from April 12 to June 12, 1968, The Borrego Mountain Earthquake of April 9, 1978, U.S. Geol. Surv. Prof. Pap., 787, 31-54, 1972.

Hamilton, R. M., and J. H. Healy, Aftershocks of the Benham nuclear explosion, Bull. Seismol. Soc. Amer., 59, 2271-2281, 1969.

Hamilton, W., and W. B. Myers, Cenozoic tectonics of the western United States, Rev. Geophys. Space Phys., 4, 509-549, 1966.

Harding, T. P., Tectonic significance and hydrocarbon trapping consequences of sequential folding synchronous with San Andreas faulting, San Joaquin Valley, California, Amer. Ass. Petrol. Geol. Bull., 60, 356-378, 1976.

Harper, J. F., Asthenosphere flow and plate motions, Geophys. J. Roy. Astron. Soc., 55, 87-110, 1978.

Harris, L. D., and K. C. Bayer, Sequential development of the Appalachian orogen above a master decollement-A hypothesis, Geology, 7, 568-572, 1979.

Healy, J. H., D. T. Griggs, W. W. Rubey, and C. B. Raleigh, The Denver earthquakes, Science, 161, 1301-1310, 1968.

Herrin, E., A comparative study of upper mantle models: Canadian Shield and Basin and Range province, in The Nature of the Solid Earth, edited by F. C. Robertson, pp. 216-234, McGraw-Hill, New York, 1972.

Herrmann, R. B., Surface wave focal mechanisms for eastern North American earthquakes with tectonic implications, J. Geophys. Res., 84(B7), 3543-3552, 1979

Herrmann, R. B., and J. A. Canas, Focal mechanism studies in the New Madrid seismic zone, Bull. Seismol. Soc. Amer., 68, 1095$1102,1978$.

Hill, D. P., A model for earthquake swarms, J. Geophys. Res., 82, 1347-1352, 1977.

Hill, M. L., and T. W. Dibblee, Jr., San Andreas, Garlock, and Big Pine faults, California-A study of the character, history, and tectonic significance of their displacements, Geol. Soc. Amer. Bull., 64, 443-458, 1953

Hill, R. L., and D. J. Beeby, Surface faulting associated with the 5.2 magnitude Galway Lake earthquake of May 31, 1975: Mojave Desert, San Bernardino County, Calif., Geol. Soc. Amer. Bull., 88, 1378-1384, 1977.

Hoffer, J. M., The Potrillo basalt field, south-central New Mexico, Cenozoic Volcanism in Southwestern New Mexico, Spec. Publ. 5, pp. 89-92, N. Mex. Geol. Soc., Socorro, 1976.

Hooker, V. E., D. L. Bickel, and J. R. Aggson, In situ determination of stress in mountainous topography, U.S. Bur. Mines Rep. Invest., 7654, 19 pp., 1972.

Hooker, V. E., J. R. Aggson, and D. L. Bickel, Improvements in the three-component borehole deformation gage and overcoring techniques, U.S. Bur. Mines Rep. Invest., 7894, 29 pp., 1974.

Homer, R. B., A. E. Stevens, H. S. Hasegawa, and G. LeBlanc, The Maniwaki, Quebec, earthquake of July 12, 1975 (abstract), Earthquake Notes, 46, 48, 1975. 
Howard, K. A., J. M. Aaron, E. E. Brabb, M. R. Brock, H. D. Gower, S. J. Hunt, D. J. Milton, W. R. Muehlberger, J. K. Nakata, G. Plafker, D. C. Prowell R. E. Wallace, and I. J. Witkind (Compilers), Preliminary map of young faults in the United States as a guide to possible fault activity, Misc. Field Stud. Map MF-916, U.S. Geol. Surv., Reston, Va., 1978.

Howell, D. E., and A. J. W. Zupan, Evidence for post-Cretaceous tectonic activity in the Westfield Creek area north of Cherow, South Carolina, Geol. Notes, 18(4), 98-105, 1974.

Hubbert, M. K., and D. G. Willis, Mechanics of hydraulic fracturing, AIME Trans., 210, 153-168, 1957.

Huff, L. C., E. Santos, and R. G. Raabe, Mineral resources of the Sycamore Canyon primitive area, Arizona, U.S. Geol. Surv. Bull., $1230-F, 19$ pp., 1966.

Hunt, C. B., Igneous geology and structure of the Mount Taylor volcanic field, New Mexico, U.S. Geol. Surv. Prof. Pap., 189-B, 1938.

Inden, R. F., and A. J. W. Zupan, Normal faulting of upper coastal plain sediments, Ideal Kaolin Mine, Langley, South Carolina, Geol. Notes, 19(4), 160-165, 1975.

Jacobeen, F. H., Jr., Seismic evidence for high-angle reverse faulting in the coastal plain of Prince Georges and Charles County, Maryland, Inf. Circ. 13, 21 pp., Md. Geol. Surv., Baltimore, 1972.

Jahns, R. H., Tectonic evolution of the Transverse Ranges province as related to the San Andreas fault system, Proceedings of the Conference on Tectonic Problems of the San Andreas Fault System, Stanford Univ. Publ. Univ. Ser. Geol. Sci., 13, 149-170, 1973.

Jicha, H. L., Jr., Geology and mineral resources of Mesa del Oro quadrangle, Socorro and Valencia counties, New Mexico, N. Mex. Bur. Mines Miner. Resour. Bull., 56, 67 pp., 1958.

Johnson, C. E., and D. M. Hadley, Tectonic implications of the Brawley earthquake swarm, Imperial Valley, California, January 1975, Bull. Seismol. Soc. Amer., 66, 1133-1144, 1976.

Johnson, R. B., Patterns and origin of radial dike swarms associated with West Spanish Peak and Dike Mountain, south-central Colorado, Geol. Soc. Amer. Bull., 72, 579-590, 1961.

Kanamori, $H$., and G. Fuis, Variation of $P$-wave velocity before and after the Galway Lake earthquake $(M=5.2)$ and the Goat Mountain earthquakes $(M=4.7,4.7)$, 1975 , in the Mojave Desert, California, Bull. Seismol. Soc. Amer. 66, 2017-2037, 1976.

Kane, M. F., Correlation of major eastern U.S. earthquake centers with mafic/ultramafic masses (abstract), Eos Trans. AGU, 57, 963 1976.

Kelley, V. C., Albuquerque - Its mountains, valley, water, and volcanoes, Scenic Trips Geol. Past 9, 101 pp., N. Mex. Bur. Mines Miner. Resour., Socorro, 1969.

Kemp, J. F., and W. C. Knight, Leucite Hills of Wyoming, Geol. Soc. Amer. Bull., 14, 305-336, 1903.

Keys, W. S., Borehole geophysics in igneous and metamorphic rocks, paper presented at the 20th Annual Symposium, Soc. Prof. Well Log Anal., 1979.

Koons, E. D., Geology of the Unikaret Plateau, northern Arizona, Geol. Soc. Amer. Bull., 56, 151-180, 1945.

Kumamoto, L., Microearthquake survey in the Gerlach-Fly Ranch area of northwestern Nevada, Colo. Sch. Mines Quart., 73(3), 4564, 1978.

Kuntz, M. A., Geologic map of the Arco-Big Southern Butte area, Butte, Blaine, and Bingham counties, Idaho, Open File Rep. 78-302, U.S. Geol. Surv., Reston, Va., 1978.

Lachenbruch, A. H., and J. H. Sass, Heat flow in the United States and the thermal regime of the crust, in The Earth's Crust, Geophys. Monogr. Ser., vol. 20, edited by J. G. Heacock, pp. 626-675, AGU, Washington, D. C., 1977.

Lachenbruch, A. H., and J. H. Sass, Models of an extending lithosphere and heat flow in the Basin and Range province, Cenozoic Tectonics and Regional Geophysics of the Western Cordillera, Geol. Soc. Amer. Mem., 152, 209-250, 1978.

Lachenbruch, A. H., and J. H. Sass, Heat flow and energetics of the San Andreas fault zone, J. Geophys. Res., 85, this issue, 1980.

Lachenbruch, A. H., J. H. Sass, and S. P. Galanis, Jr., New heat flow results from southern California (abstract), Eos Trans. AGU, 59, $1051,1978$.

Lambert, W., Notes on the Late Cenozoic geology of the Taos-Questa area, New Mexico, N. Mex. Geol. Soc. Field Conf. Guideb., 17, 43$50,1966$.

Langer, C. J., G. R. Keller, and R. B. Smith, A study of the aftershocks of the October 1, 1972, $M=4.7$, Heber City, Utah, earthquake, in Earthquake Studies in Utah, 1850-1978, edited by W. J.
Arabasz, R. B. Smith, and W. D. Richins, pp. 383-394, University of Utah, Salt Lake City, 1979.

Langston, C. A., and R. Butler, Focal mechanism of the August I, 1975, Oroville, earthquake, Bull. Seismol. Soc. Amer., 66, 1111$1120,1976$.

Leblanc, G., and G. Buchbinder, Second microearthquake survey of the St. Lawrence Valley near La Malbaie, Quebec, Can. J. Earth Sci., 14, 2778-2789, 1977.

Leblanc, G., A. E. Stevens, and R. J. Wetmiller, A microearthquake survey of the St. Lawrence Valley near La Malbaie, Quebec, Can. J. Earth Sci., 10, 42-53, 1973.

Leeds, A. R., L. Knopoff, and E. G. Kausel, Variations of upper mantle structure under the Pacific Ocean, Science, 186, 141-143, 1975.

Lockwood, J. P., and J. G. Moore, Regional extension of the Sierra Nevada, California, on conjugate microfault sets, $J$. Geophys. Res., 84, 6041-6049, 1979.

Luedke, R. G., and R. L. Smith, Map showing distribution, composition, and age of late Cenozoic volcanic centers in Arizona and New Mexico, Misc. Invest. Map I-1091, U.S. Geol. Surv., Reston, Va. $1978 a$.

Luedke, R. G., and R. L. Smith, Map showing distribution, composition, and age of late Cenozoic volcanic centers in Colorado, Utah and southern Wyoming, Misc. Invest. Map I-1091-B, U.S. Geol. Surv., Reston, Va., $1978 b$.

Malone, S. D., G. H. Rothe, and S. W. Smith, Details of microearthquake swarms in the Columbia Basin, Washington, Bull. Seismol. Soc. Amer., 65, 855-864, 1975.

McDowell, F. W., K-Ar ages of igneous rocks from the western United States, Isochron/West, 2, 1-16, 1971.

McEvilly, T. V., Preliminary seismic data, June-July 1966, section of Parkfield earthquakes of June 27-29, 1966, Monterey and San Luis Obispo counties, California-Preliminary report, Bull. Seismol. Soc. Amer., 56, 967-971, 1966.

McGarr, A., and N. C. Gay, State of stress in the earth's crust, Ann. Rev. Earth Planet. Sci., 6, 405-436, 1978.

McKenzie, D. P., The relationship between fault plane solutions for earthquakes and the directions of the principal stresses, Bull. Seismol. Soc. Amer., 59, 591-601, 1969.

McKenzie, D. P., Plate tectonics, in The Nature of the Solid Earth, edited by E. C. Robertson, pp. 323-360, McGraw-Hill, New York, 1972.

McKeown, F. H., Hypothesis: Many earthquakes in the central and southeastern United States are causally related to mafic intrusive bodies, J. Res. U.S. Geol. Surv., 6, 41-50, 1978.

McKinlay, P. F., Geology of Costilla and Latir Peak quadrangles, Taos County, New Mexico, N. Mex. Bur. Mines Miner. Resour. Bull., 42, 32 pp., 1956.

Mercier, J.-C. C., Magnitude of the continental lithospheric stresses inferred from rheomorphic petrology, J. Geophys. Res., 85 , this issue, 1980.

Merrill, R. H., In situ determination of stress by relief techniques, in State of Stress in the Earth's Crust, edited by W. R. Judd, pp. 343369, Elsevier, New York, 1964

Merrill, R. K., and T. L. Péwé, Late Cenozoic geology of the White Mountains, Arizona, Tech. Spec. Pap., 1, 65 pp., Ariz. Bur. of Geol. and Miner. Technol., Tucson, 1977.

Minster, J. B., and T. H. Jordan, Present-day plate motions, $J$. Geophys. Res., 83(B11), 5331-5354, 1978.

Mixon, R. B., and W. L. Newell, Stafford fault system: Structures documenting Cretaceous and Tertiary deformation along the Fall Line in northeastern Virginia, Geology, 5, 437-440, 1977.

Moench, R. H., and J. S. Schlee, Geology and uranium deposits of the Laguna district, New Mexico, U.S. Geol. Surv. Prof. Pap., 519, 117 pp., 1967.

Moore, J. G., and E. duBray, Mapped offset on the right-lateral Kern Canyon fault, southern Sierra Nevada, California, Geology, 6, 205208, 1978.

Moore, R. B., and E. W. Wolfe, Geologic map of the eastern San Francisco volcanic field, Arizona, Misc. Invest. Ser. Map I-953, U.S. Geol. Surv., Reston, Va., 1976.

Morgan, W. J., Plate motions and deep mantle convection, Studies in Earth and Space Sciences, Geol. Soc. Amer. Mem., 132, 7-22, 1972.

Muffler, L. J. P., Geology of the Frenchie Creek quadrangle, northcentral Nevada, U.S. Geol. Surv. Bull., 1179, 99 pp., 1964.

Muffler, L. J. P. (Ed.), Assessment of geothermal resources of the United States—1978, U.S. Geol. Surv. Circ., 790, 163 pp., 1979. 
Muller, O. H., and D. D. Pollard, The state of stress near Spanish Peaks, Colorado, determined from a dike pattern, Pure Appl. Geophys., 115, 69-86, 1977.

Nakamura, K., Volcanoes as possible indicators of tectonic stress orientation-Principle and proposal, J. Volcanol. Geotherm. Res., 2, 116, 1977.

Nakamura, K., K. H. Jacob, and J. N. Davies, Volcanoes as possible indicators of tectonic stress orientation-Aleutians and Alaska, Pure Appl. Geophys., 115, 87-112, 1978.

Natali, S., D. Gish, and M. L. Sbar, A microearthquake survey of northeastern Sonora, Mexico (abstract), Eos Trans. AGU, 60, 894, 1979.

Nelson, W. A., Geology and mineral resources of Albemarle County, Va. Div. Geol. Bull., 77, 92 pp., 1962.

Obert, L., In situ determination of stress in rock, Miner. Eng., 14(8), 51-58, 1962.

O'Connell, D., C. Bufe, and M. D. Zoback, Microearthquakes and faulting in the area of New Madrid-Reelfoot Lake, Tennessee, U.S. Geol. Surv. Prof. Pap., in press, 1980.

Odé, H., A note concerning the mechanism of artificial and natural hydraulic fracture systems, Colo. Sch. Mines Quart., 51, 19-29, 1956.

Oliver, J., T. Johnson, and J. Dorman, Postglacial faulting and seismicity in New York and Quebec, Can. J. Earth Sci., 7, 579-590, 1970.

Overbey, W. K., Jr., and R. L. Rough, Surface studies predict orientation of induced formation fractures, Prod. Mon., 32(8), 16-19, 1968.

Parsons, R. C., and H. D. Dahl, A study of the causes of toof instability in the Pittsburgh coal seam, in Proceedings of the 7th Canadian Rock Mechanics Symposium, Edmonton, Mines Branch, Department of Energy, Mines and Resources, Ottawa, 1972.

Pavlis, T. L., and R. B. Smith, Slip vectors on faults near Salt Lake City, Utah, from Quaternary displacements and seismicity, Bull. Seismol. Soc. Amer. in press, 1980.

Pavoni, N., A study of earthquake focal mechanisms in the Hollister area, southern Coast Ranges, California, Tectonophysics, 52, 363$371,1979$.

Pechmann, J. C., Tectonic implications of small earthquakes in the central Transverse Ranges, California, U.S. Geol. Surv. Prof. Pap., in press, 1980.

Pitt, A. M., and D. W. Steeples, Microearthquakes in the Mono Lakenorthern Owens Valley, California, region from September 28 to October 18, 1970, Bull. Seismol. Soc. Amer., 65, 835-844, 1975.

Pitt, A. M., C. S. Weaver, and W. Spence, The Yellowstone Park earthquake of June 30, 1975, Bull. Seismol. Soc. Amer., 69, 187-205, 1979.

Power, D. V., C. L. Schuster, R. Hay, and J. Twombly, Detection of hydraulic fracture orientation and dimensions in cased wells. J. Petrol. Tech., 28, 1116-1124, 1976.

Prescott, W. H., J. C. Savage, and W. T. Kinoshita, Strain accumulation rates in the western United States between 1970 and 1978, $J$. Geophys. Res., 84, 5423-5435, 1979.

Prowell, D. C., Index of Cretaceous and Cenozoic faults in the eastern U.S., Misc. Field Invest. Map, U.S. Geol. Surv., Reston, Va., in press, 1980.

Prowell, D. C., and B. J. O'Connor, Belair fault zone: Evidence of Tertiary fault displacement in eastern Georgia, Geology, 6, 681684, 1978.

Prowell, D. C., B. J. O'Connor, and M. Rubin, Preliminary evidence for Holocene movement along the Belair fault zone near Augusta, Georgia, U.S. Open File Rep. 75-680, 16 pp., U.S. Geol. Surv., Reston, Va., 1975.

Raleigh, C. B., J. H. Healy, and J. D. Bredehoeft, Faulting and crustal stress at Rangely, Colorado, in Flow and Fracture of Rocks, Geophys. Monogr. Ser., vol. 16, edited by H. C. Heard, et al., pp. 275-284, AGU, Washington, D. C., 1972.

Reiter, M., C. L. Edwards, H. Hartman, and C. Weideman, Terrestrial heat flow along the Rio Grande rif, New Mexico and southern Colorado, Geol. Soc. Amer. Bull., 86, 811-818, 1975.

Reiter, M., A. J. Mansure, and C. Shearer, Geothermal characteristics of the Colorado Plateau, Tectonophysics, in press, 1980.

Reynolds, M. W., Character and extent of basin-range faulting, western Montana and east-central Idaho, in 1979 Basin and Range Symposium, pp. 185-193, Rocky Mountain Association of Geologists and Utah Geologists Association, Denver, Colo., 1979.

Richardson, R. M., S. C. Solomon, and N. H. Sleep, Intraplate stress as an indicator of plate tectonic driving forces, $J$. Geophys. Res., 81 , 1847-1856, 1976.

Richardson, R. M., S. C. Solomon, and N. H. Sleep, Tectonic stress in the plates, Rev. Geophys. Space Phys., 17, 981-1019, 1979.

Richins, W. D., Earthquake swarm near Denio, Nevada, February to April, 1973, ARPA Tech. Rep., Univ. of Nev., Reno, 1974.

Richins, W. D., The Hansel Valley, Utah, earthquake sequence of November, 1976, in Earthquake Studies in Utah, 1850 to 1978, edited by W. J. Arabasz, R. B. Smith, and W. D. Richins, pp. 409421, University of Utah, Salt Lake City, 1979.

Roegiers, J. C., and C. Fairhurst, The deep stress probe-A tool for stress determination (abstract), in New Horizons in Rock Mechanics; Proceedings, 14th Symposium on Rock Mechanics, edited by H. R. Hardy, Jr., and R. Stefanko, p. 755-760, American Society of Civil Engineers, New York, 1973.

Rogers, A. M., and W. H. K. Lee, Seismic study of earthquakes in the Lake Mead, Nevada-Arizona region, Bull. Seismol. Soc. Amer., 66, 1657-1681, 1976.

Romney, C., Seismic waves from the Dixie Valley-Fairview Peak (Nevada) earthquakes, Bull. Seismol. Soc. Amer., 47, 301-319, 1957.

Russell, B. J., A structural break and kinematics of faulting in the White Mountains, California (abstract), Geol. Soc. Amer. Abstr. Programs, 9, 491, 1977.

Ryall, A., The Hebgen Lake, Montana, earthquake of August 18, 1959: $P$ waves, Bull. Seismol. Soc. Amer., 52, 235-271, 1962.

Ryall, A., and S. D. Malone, Earthquake distribution and mechanism of faulting in the Rainbow Mountain-Dixie Valley-Fairview Peak area, central Nevada, J. Geophys. Res., 76, 7241-7248, 1971.

Ryall, A., and K. Priestley, Seismicity, secular strain, and maximum magnitude in the Excelsior Mountains area, western Nevada and eastern California, Geol. Soc. Amer. Bull., 86, 1585-1592, 1975.

Ryall, A., D. B. Slemmons, and L. D. Gedney, Seismicity, tectonism, and surface faulting in the western United States during historic time, Bull. Seismol. Soc. Amer., 56, 1105-1136, 1966.

Sanford, A. R., K. H. Olsen, and L. H. Jaksha, Seismicity of the Rio Grande rift, in Rio Grande Rift: Tectonics and Magmatism, edited by R. E. Riecker, pp. 145-168, AGU, Washington, D. C., 1979.

Sass, J. H., and J. P. Ziagos, Heat flow from a corehole near Charleston, South Carolina, U.S. Geol. Surv. Prof. Pap., 1028-H, 115-117, 1977.

Sass, J. H., A. H. Lachenbruch, R. J. Munroe, G. W. Greene, and T. H. Moses, Jr., Heat flow in the western United States, $J$. Geophys. Res., 76, 6376-6413, 1971.

Sbar, M. L., and L. R. Sykes, Contemporary compressive stress and seismicity in eastern North America: An example of intraplate tectonics, Geol. Soc. Amer. Bull., 84, 1861-1882, 1973.

Sbar, M. L., and L. R. Sykes, Seismicity and lithospheric stress in New York and adjacent areas, J. Geophys. Res., 82, 5771-5786, 1977.

Sbar, M. L., M. Barazangi, J. Dorman, C. H. Scholz, and R. B. Smith, Tectonics of the Intermountain Seismic Belt, western United States: Microearthquake seismicity and composite fault plane solutions, Geol. Soc. Amer. Bull., 83, 13-28, 1972.

Scarborough, R. B., and M. Shaffiqullah, Cenozoic sediments and tectonics, Arizona Basin and Range province (abstract), Geol. Soc. Amer. Abstr. Programs, 11, 511, 1979.

Schäfer, K., Recent thrusting in the Appalachians, Nature, 280, 223226, 1979.

Schaff, C. S., The 1968 Adel, Oregon, earthquake swarm, M.S. thesis, Univ. of Nev., Reno, 1976.

Schultz, A. R., and W. Cross, Potash-bearing rocks of the Leucite Hills, Sweetwater County, Wyoming, U.S. Geol. Surv. Bull., 512, 39 pp., 1912.

Scott, D. H., and N. J. Trask, Geology of the Lunar Crater volcanic field, Nye County, Nevada, U.S. Geol. Surv. Prof. Pap., 599-I, 22 Pp., 1971.

Seeber, L., and J. G. Armbruster, The 1886 Charleston, South Carolina, earthquake and the Appalachian detachment, submitted to $J$. Geophys. Res., 1980.

Sharp, R. V., Surface rupturing in Imperial Valley during the earthquake swarm of January-February, 1975, Bull. Seismol. Soc. Amer., 66, 1145-1154, 1976.

Shoemaker, E. M., R. L. Squires, and M. J. Abrams, Bright Angel and Mesa Butte fault systems of northern Arizona, Cenozoic Tectonics and Regional Geophysics of the Western Cordillera, Geol. Soc. Amer. Mem. 152, 341-367, 1978. 
Skinner, E. H., G. G. Waddell, and J. P. Conway, In situ determination of rock behavior by overcore stress relief method, physical property measurements and initial deformation method, U.S. Bur. Mines Rep. Invest., 7962, 30 pp., 1974.

Slemmons, D. B., Pliocene and Quaternary crustal movements of the Basin-and-Range province, USA, J. Geosci., 10, 91-101, 1967.

Slemmons, D. B., D. Van Wormer, E. J. Bell, and M. L. Silberman, Recent crustal movements in the Sierra Nevada-Walker Lane region of California-Nevada, I, Rate and style of deformation, Tectonophysics, 52, 561-570, 1979.

Smith, C. T., Geology of the Little Black Peak quadrangle, Socorro and Lincoln counties, New Mexico, N. Mex. Geol. Soc. Field Conf. Guideb., 15, 92-99, 1964.

Smith, M. B., Effect of fracture azimuth on production with application to the Wattenberg gas field, paper presented at 54th Annual Fall Technical Conference, Soc. of Petrol. Eng., Amer. Inst. of Mech. Eng., Las Vegas, Sept. 23-26, 1979.

Smith, R. B., Intraplate tectonics of the western North American plate, Tectonophysics, 37, 323-336, 1977.

Smith, R. B., Seismicity, crustal structure, and intraplate tectonics of the interior of the western Cordillera, Cenozoic Tectonics and Regional Geophysics of the Western Cordillera, Geol. Soc. Amer. Mem., 152, 111-114, 1978.

Smith, R. B., and A. G. Lindh, Fault-plane solutions of the western United States: A compilation, Cenozoic Tectonics and Regional Geophysics of the Western Cordillera, Geol. Soc. Amer. Mem., 152, 107-109, 1978.

Smith, R. B., and M. L. Sbar, Contemporary tectonics and seismicity of the western United States with emphasis on the intermountain seismic belt, Geol. Soc. Amer. Bull., 85, 1205-1218, 1974.

Smith, R. B., P. Winkler, J. Anderson, and C. H. Scholz, Source mechanisms of microearthquakes associated with underground mines in Utah, Bull. Seismol. Soc. Amer., 64, 1295-1317, 1974a.

Smith, R. B., R. T. Shuey, R. O. Freidline, R. M. Otis, and L. B. Alley, Yellowstone hot spot: New magnetic and seismic evidence, $\mathrm{Ge}$ ology, 2, 451-455, 1974b.

Smith, R. B., R. T. Shuey, J. R. Pelton, and J. P. Bailey, Yellowstone hot spot: Contemporary tectonics and crustal properties from earthquake and aeromagnetic data, J. Geophys. Res., 82, 3665-3676, 1977.

Smith, R. L., R. A. Bailey, and C. S. Ross, Geologic map of the Jemez Mountains, New Mexico, Misc. Geol. Invest. Map 1-571, U.S. Geol. Surv., Reston, Va., 1970.

Smith, S. W., Skagit Valley earthquakes of 1974-1975 (abstract), Eos Trans. $A G U, 57,90,1976$.

Smith, S. W., and R. Kind, Observations of regional strain variations, J. Geophys. Res., 77, 4976-4980, 1972.

Speed, R. C., and A. H. Cogbill, Candelaria and other left-oblique slip faults of the Candelaria region, Nevada, Geol. Soc. Amer. Bull., 90, 149-163, 1979.

Stauder, W., and O. W. Nuttli, Seismic studies: South central Illinois earthquake of November 9, 1968, Bull. Seismol. Soc. Amer., 60(3), 973-981, 1970

Stein, S., N. H. Sleep, R. J. Geller, S.-C. Wang, and G. C. Kroeger, Earthquakes along the passive margin of eastern Canada, Geophys. Res. Lett., 6, 537-540, 1979.

Stevenson, P. R., Microearthquakes of Flathead Lake, Montana: A study using automatic earthquake processing, Bull. Seismol. Soc. Amer., 66, 61-80, 1976.

Stewart, J. H., Basin-range structure in western North America: A review, Cenozoic Tectonics and Regional Geophysics of the Western Cordillera, Geol. Soc. Amer. Mem., 152, 1-31, 1978.

Stierman, D. J., and W. C. Ellsworth, Aftershocks of the February 21, 1973 Point Mugu, California, earthquake, Bull. Seismol. Soc. Amer., 66(6), 1931-1952, 1976.

Strubhar, M. K., J. L. Fitch, and E. E. Glenn, Jr., Multiple vertical fractures from an inclined wellbore-A field experiment, $J$. Petrol. Tech., 27, 641-647, 1975.

Suppe, J., C. Powell, and R. Berry, Regional topography, seismicity, Quaternary volcanism, and the present-day tectonics of the western United States, Amer. J. Sci., 275-A, 397-436, 1975.

Swanberg, C. A., and P. Morgan, The linear relation between temperatures based on the silica content of groundwater and regional heat flow: A new heat flow map of the United States, Pure Appl. Geophys., 117, 227-241, 1978 .

Swanberg, C. A., B. J. Mitchell, R. L. Lohse, and D. D. Blackwell,
Heat flow in the Upper Mississippi Embayment (abstract), Eos Trans. $A G U, 60,310,1979$.

Sykes, L. R., Intraplate seismicity, reactivation of preexisting zones of weakness, alkaline magmatism, and other tectonism postdating continental fragmentation, Rev. Phys. Space Phys., 16(4), 621-688, 1978.

Tarr, A. C., Recent seismicity near Charleston, South Carolina, and its relationship to the August 31, 1886, earthquake, U.S. Geol. Surv. Prof. Pap., 1028-D, 43-57, 1977.

Thaden, R. E., S. Merrin, and O. B. Raup, Geologic map of the Grants SE quadrangle, Valencia County, New Mexico, Geol. Quad. Map GQ-682, U.S. Geol. Surv., Reston, Va., 1967.

Thompson, G. A., and D. B. Burke, Rate and direction of spreading in Dixie Valley, Basin and Range province, Nevada, Geol. Soc Amer. Bull., 84, 627-632, 1973.

Thompson, G. A., and D. B. Burke, Regional geophysics of the Basin and Range province, Ann. Rev. Earth Planet. Sci., 2, 213-228, 1974.

Thompson, G. A., and M. L. Zoback, Regional geophysics of the Colorado Plateau, Tectonophysics, 61, 149-181, 1979.

Tobin, D. G., and L. R. Sykes, Seismicity and tectonics of the northeastern Pacific Ocean, J. Geophys. Res., 73, 3821-3845, 1968.

Trexler, D. T., E. J. Bell, and G. R. Roguemore, Evaluation of lineament analysis as an exploration technique for geothermal energy, western and central Nevada, final report, contract EY-76-S-08-067, U.S. Dep. of Energy, Washington, D. C., 1978.

Trimble, A. B., and R. B. Smith, Seismicity and contemporary tectonics of the Hegben Lake-Yellowstone Park region, J. Geophys. Res., 80, 733-741, 1975

Tsai, Y.-B., and K. Aki, Source mechanism of the Truckee, California, earthquake of September 12, 1966, Bull. Seismol. Soc. Amer., $60,1199-1208,1966$.

Turcotte, D. L., J. L. Ahern, and J. M. Bird, The state of stress at continent margins, Tectonophysics, 42, 1-28, 1977.

Untermann, G. E., and B. R. Untermann, Geology of Uintah County, Utah Geol. Mineral Surv. Bull., 72, 112 pp., 1964.

Vernon, R. O., Geology of Citrus and Levy counties, Florida, Fla. Geol. Surv. Geol. Bull., 33, 256 pp., 1951.

von Schonfeldt, H. A., R. O. Kehle, and K. E. Gray, Mapping of stress field in the upper earth's crust of the U.S., final technical report, grant 14-08-0001-1222, 78 pp., U.S. Geol. Surv., Reston, Va. 1973.

Voss, J. A., and R. B. Herrmann, A surface wave study of the June 16, 1978 Texas earthquake, Earthquake Notes, 51, 3-14, 1980.

Walcott, R. I., Gravity flexure and the growth of sedimentary basins at a continent edge, Geol. Soc. Amer. Bull., 83, 1845-1848, 1972.

Wallace, R. E., Geometry of shearing stress and relation to faulting, $J$. Geol., 59, 118-130, 1951.

Wallace, R. E., Strain pattern represented by scarps formed during the earthquakes of October 2, 1915, Pleasant Valley, Nevada, Tectonophysics, 52, 599, 1979.

Wanek, A. A., Reconnaissance geologic map of parts of Harding, San Miguel, and Mora counties, New Mexico, Oil Gas Invest. Map OM208, U.S. Geol. Surv., Reston, Va., 1962.

Watts, A. B., and W. B. F. Ryan, Flexure of the lithosphere and continental margins, Tectonophysics, 36, 25-44, 1976.

Weaver, C. S., and D. P. Hill, Earthquake swarms and local crustal spreading along major strike-slip faults in California, Pure Appl. Geophys., 117, 51-64, 1979.

Weaver, C. S., A. M. Pitt, and D. P. Hill, Crustal spreading direction of the Snake River plain-Yellowstone system (abstract), Eos Trans. $A G U, 60,946,1979$.

Weber, R. H., Geology of the Carrizozo quadrangle, New Mexico, $N$. Mex. Geol. Soc. Field Conf. Guideb., 15, 100-109, 1964.

Wentworth, C. M., and M. Mergner-Keefer, Regenerate faults of small Cenozoic displacement: Probable earthquake sources in the southeastern U.S., Studies Related to the Charleston, South Carolina, Earthquake of 1886 -Early Mesozoic History of the Southern Atlantic Coastal Plain and Continental Shelf, U.S. Geol. Surv. Prof. Pap., in press, 1980.

Whitcomb, J. H., C. R. Allen, J. D. Garmany, and J. A. Hileman, San Fernando earthquake series, 1971: Focal mechanisms and tectonics, Rev. Geophys. Space Phys., 11(3), 369-730, 1973.

White, W. A., Post-Cretaceous faulting in Virginia and North Carolina, Geol. Soc. Amer. Bull., 63, 745-748, 1952.

Wilcox, R. E., T. P. Harding, and D. R. Seely, Basic wrench tectonics, Amer. Ass. Petrol. Geol. Bull., 57, 74-96, 1973. 
Winchester, D. E., Geology of Alamosa Creek valley, Socorro County, New Mexico, with special reference to the occurrence of oil and gas, U.S. Geol. Surv. Bull., 716-A, 1-15, 1920.

Wood, G. H., Jr., S. A. Northrup, and R. L. Griggs, Geology and stratigraphy of Koehler and Mount Laughlin quadrangles and parts of Abbott and Springer quadrangles, eastern Colfax County, New Mexico, Oil Gas Invest. Map OM-141, U.S. Geol. Surv., Reston, Va., 1953.

Woodward, L. A., Rate of crustal extension across the Rio Grande rift near Albuquerque, New Mexico, Geology, 5, 269-272, 1977.

Woodworth, J. B., Postglacial faults of eastern New York, Geology, $12,5-28,1907$.

Woollard, G. P., Tectonic activity in North America as indicated by earthquakes, in The Earth's Crust and Upper Mantle, Geophys. Monogr. Ser., vol. 13, edited by P. J. Hart, pp. 125-133, AGU, Washington, D. C., 1969.

Wright, H. E., Jr., Tertiary and Quaternary geology of the Lower Rio Puerco area, New Mexico, Geol. Soc. Amer. Bull., 57, 383-456, 1946.

Wright, L., Late Cenozoic fault patterns and stress fields in the Great Basin and westward displacement of the Sierra Nevada block, Geology, 4, 489-494, 1976.

Wright, L. A., J. K. Otton, and B. W. Troxel, Turtleback surfaces of Death Valley viewed as phenomena of extensional tectonics, Geology, 2, 53-54, 1974.

Yoder, H. S., Jr., Generation of Basaltic Magma, 265 pp., National Academy of Sciences, Washington, D. C., 1976.

York, J. E., and J. E. Oliver, Cretaceous and Cenozoic faults in eastern North America, Geol. Soc. Amer. Bull., 87, 1105-1114, 1976.

Zemanek, J., E. E. Glenn, L. J. Norton, and R. L. Caldwell, Formation evaluation by inspection with the borehole televiewer, Geophysics, 35(2), 254-269, 1970.

Zoback, M. D., J. H. Healy, and J. C. Roller, Preliminary stress mea- surements in central California using the hydraulic fracturing technique, Pure Appl. Geophys., 115, 135-152, 1977.

Zoback, M. D., J. H. Healy, J. C. Roller, G. S. Gohn, and B. B. Higgins, Normal faulting and in situ stress in the South Carolina coastal plain near Charleston, Geology, 6, 147-152, 1978.

Zoback, M. D., R. M. Hamilton, A. J. Crone, D. P. Russ, F. A. McKeown, and S. R. Brockman, Recurrent intraplate tectonism in the New Madrid seismic zone, Science, 209, 971-976, 1980a.

Zoback, M. D., Tsukahara, H., and S. Hickman, Stress measurements in the vicinity of the San Andreas fault: Implications for the magnitude of shear stress at depth, $J$. Geophys. Res., 85, this issue, $1980 b$.

Zoback, M. L., Mid-Miocene rifting in north-central Nevada: A detailed study of late Cenozoic deformation in the northern Basin and Range, Ph.D. thesis, 247 pp., Stanford Univ., Stanford, Calif., 1978.

Zoback, M. L., State of stress in the southern Basin and Range province and Colorado Plateau (abstract), Eos Trans. AGU, 60, 311, 1979.

Zoback, M. L., and G. A. Thompson, Basin and Range rifting in northern Nevada: Clues from a mid-Miocene rift and its subsequent offsets, Geology, 6, 111-116, 1978.

Zoback, M. L., and M. D. Zoback, Faulting patterns in north-central Nevada and strength of the crust, J. Geophys. Res., 85, 275-284, 1980.

Zoback, M. L., R. E. Anderson, and G. A. Thompson, Cenozoic evolution of the state of stress and style of tectonism in the western United States, Phil. Trans. Roy. Soc. London, in press, 1980.

Zupan, A. J. W., and W. H. Abbot, Clastic dikes: Evidence for postEocene(?) tectonics in the upper coastal plain of South Carolina, Geol. Notes, 19(1), 14-23, 1975.

(Received November 29, 1979; revised July 21,1980 ; accepted August 7, 1980.) 